\title{
BENEMEJÍS Y SEÑERA ANTE LA EXPULSIÓN DE LOS MORISCOS ${ }^{1}$
}

\author{
Primitivo J. Pla Alberola \\ Universidad de Alicante
}

\section{Resumen}

En este trabajo se aborda el análisis de dos pequeños señoríos del extenso término de Játiva, ubicados en la actual comarca de la Ribera, en los primeros años del siglo XVII, con la expulsión de los moriscos como referente fundamental. Se estudian las rentas señoriales antes y después de la expulsión, las deudas del señor y las que debe asumir de sus vasallos extrañados, las dificultades de la repoblación y los problemas con los acreedores. alquería.

Palabras clave: Expulsión de los moriscos, carta puebla, rentas señoriales, censal,

\begin{abstract}
This paper analyses two small feudal estates in the sprawling city of Jativa, located in today's Ribera district, during the early $17^{\text {th }}$ century. With the expulsion of the Moors as a fundamental reference point, feudal revenue before and after the expulsion is studied, as well as the overlord's debts and the debts he had to take on from his absents vassals, repopulation difficulties and problems with creditors.
\end{abstract}

Keywords: Expulsion of the moors, town charter, feudal revenue, census, debts.

\section{I.- INTRODUCCIÓN}

El análisis de los señoríos valencianos cuenta con una nutrida bibliografía, fruto del interés que han suscitado por su fuerte implantación en el reino y las peculiaridades de su evolución histórica, hasta el punto de que Gregorio Colás considera que «sólo en

1. El presente trabajo se inscribe en el proyecto de investigación «Señores y señorios en la Valencia moderna. Aspectos sociales y económicos», financiado por el Ministerio de Ciencia y Tecnologia, referencia BHA2003-08362 y los fondos FEDER. 
Valencia el señorío como tal se ha configurado como tema específico» $;{ }^{2}$ bien es verdad que en los últimos años parece que el interés por el tema ha decaído un tanto. ${ }^{3}$ No es menor la atención dedicada por la reciente historiografía al estudio de los moriscos y su expulsión. Se impone por la importancia de esa minoría, que suponía la tercera parte de la población valenciana, y su dramático fin.

En el cruce de ambos caminos está el análisis del impacto de la expulsión de los moriscos en los señoríos valencianos, el cual tiene un particular interés porque la mayor parte de los moriscos eran en 1609 vasallos de señorío y su expulsión supuso un hito decisivo en la trayectoria del régimen señorial. ${ }^{4}$ Se han escrito muchas páginas sobre el particular, sin que ello quiera decir que el debate esté agotado, de forma que cabe augurar una actualización del mismo en los próximos años, si se quiere por un factor de tipo oportunista.

En el terreno que más inmediatamente nos interesa, conocemos las rentas de algunos señoríos antes y, sobre todo, después de la expulsión, está analizada una pequeña parte de la ingente documentación generada en torno al problema de la deuda contraída por los señores y de la que asumieron de sus vasallos tras el extrañamiento, se ha estudiado un conjunto importante de las cartas pueblas que regularon el proceso de repoblación, debatida su incidencia en la configuración del parcelario, el tamaño de las explotaciones, el paisaje agrario y un largo etcétera. Pero la información disponible es muy desigual y, a menudo, uno tiene la impresión de que se han planteado hipótesis demasiado generales a partir de los aún pocos ejemplos estudiados en determinadas cuestiones, con el riesgo de confundir el caso con la categoría.

En este contexto, el objetivo del presente trabajo no puede ser muy ambicioso, pues estudiaremos unos señoríos de escasa entidad a partir, además, de una documentación que deja muchas preguntas sin respuesta. El grueso de la documentación que lo sustenta lo localicé, de forma casual, hace ya una veintena de años y cuando mis objetivos eran otros. Es una documentación interesante, que parcialmente utilicé en un trabajo anterior, ${ }^{5}$ aunque muy circunscrita en el tiempo y en el espacio. Hubiese querido complementarla con otra que me permitiese centrar mejor las cuestiones que abordaré aquí, pero la fortuna me ha sido esquiva y los esfuerzos realizados hasta el momento no han tenido un éxito proporcionado.

2. Gregorio COLÁS LATORRE: «La historiografía sobre el señorío tardofeudal». En Eliseo SARASA SÁNCHEZ y Eliseo Serrano Martin (Eds.): Señorio y feudalismo en la Peninsula Ibérica (ss. XII-XIX). Institución «Fernando el Católico», Zaragoza, 1993, vol. 1, p. 52.

3. David BERNABÉ GIL: «Quince años de estudios sobre el régimen señorial valenciano durante la Edad Moderna». Congreso Señorio y Feudalismo quince años después. Zaragoza, 11-12 de noviembre de 2004 (en prensa).

4. Es obligado recordar dos importantes trabajos por sus aportaciones a estos temas: Eugenio CISCAR PALLARÉs: Tierra y señorio en el País Valenciano (1570-1620). Del Cenia al Segura, Valencia, 1977; y Antonio GIL OlCINA: La propiedad señorial en tierras valencianas. Del Cenia al Segura, Valencia, 1979.

5. Primitivo J. Pla Alberola: «La carta puebla de Señera en 1445». Anales de la Universidad de Alicante. Historia medieval (Alicante), n 9 (1992-1993), pp. 279-295. 
El núcleo de la documentación al que he aludido se encuentra en un expediente no muy voluminoso conservado en el Archivo Histórico Nacional: «Don Francisco Joaquín Sans, señor de los lugares de Benemixix y Seniera, sobre el daño y perjuicio que se le ha seguido con motibo de la expulsión de los moriscos» ${ }^{6}$ En él se cosen el pedimento del señor solicitando la minoración de la deuda a que estába obligado por la grave quiebra de sus rentas, la oposición de los acreedores, las respectivas réplica y contrarréplica, más un «cálculo y bilanço» final de las posturas de las partes realizado por Mateo Ferro. Completan el expediente traslados de las cartas pueblas de Señera en 1445 y 1611, de las dos de Benemejís de 1611, dos certificados notariales de establecimientos a los nuevos pobladores y otro de bienes dotales del señor, sendos informes de las rentas de Benemejís y Señera antes de la expulsión y los testimonios de unos pocos testigos de oficio. En total, 88 folios, según consta en la misma portada del expediente, aunque son algunos más, pues el balance final tiene una foliación aparte, como documento añadido, y sólo se numera la camisa del traslado, en cuarto, de la carta puebla de 1445 .

Añadir que los memoriales del señor los presentó personalmente el mismo D. Francisco Joaquín Sanz, sin que en momento alguno aparezca citado un procurador. Por parte de los acreedores actuaron dos representantes que podemos considerar como muy cualificados: mosén Bartolomé Sebastián, presbítero, y el Dr. D. Baltasar Sanz de la Llosa. El primero figura en otros documentos algo posteriores como «procurador general de los acreedores censalistas de la ciudad y reyno de Valencia», y tiene una intensa actividad que hace que «pueda ser considerado como un auténtico profesional del género memorial», en palabras de Emilia Salvador, ${ }^{7}$ quien conocería perfectamente los argumentos barajados en el debate entre señores y acreedores. D. Baltasar Sanz de la Llosa era hijo de quien en esos momentos presidía de forma interina la Real Audiencia, y él mismo llegó a ser oidor de causas civiles en el supremo tribunal del reino entre 1623 y $1642 ;{ }^{8}$ además, era parte especialmente interesada como uno de los principales acreedores del señor de Benemejís y Señera.

El objetivo de esta documentación era, pues, claro: dilucidar si las pérdidas sufridas por el señor a raíz de la expulsión de los moriscos hacían o no viable el pago de las deudas a que estaba obligado, si podía satisfacer los intereses en su integridad o, por el contrario, verse beneficiado por la reducción de los mismos e, incluso, solicitar tasación de alimentos; y esa intencionalidad debemos tenerla bien presente en cualquier momento. Por lo tanto, estamos ante un expediente cuyo origen está en las disposiciones promulgadas por el Dr. D. Salvador Fontanet, juez comisario nombrado

6. ARCHIVO HISTÓRICO NACIONAL (AHN): Consejos, 22.243/4.

7. Emilia SALVADOR ESTEBAN: «La cuestión de los censales y la expulsión de los moriscos valencianos». Estudis (Valencia), n² 24 (1998), pp. 128, 137 y 140. Véase también Eugenio CISCAR PALLARÉs: Moriscos, nobles y repobladores. Edicions Alfons el Magnànim, Valencia, 1993, pp. 141, 156, 188, 199, 203 y 217.

8. Teresa CANET APARISI: La Magistratura Valenciana (s. XVI-XVII). Departamento de Historia Moderna, Valencia, 1990, p. 266. Para un mayor detalle de su trayectoria, véase Vicente GrAULLERA. SANZ: Juristas valencianos del siglo XVII. Generalitat Valenciana; Valencia, 2003. 
por Felipe III para impulsar y regular la repoblación del reino, en su pregón de 12 de enero de 1611 y reiteradas y ampliadas en el de 15 de julio del mismo año. ${ }^{9}$ En éste se exige a quienes hayan repoblado sus lugares que presenten, en quince días, traslado de las cartas pueblas y certificatoria notarial de los establecimientos individuales; el mismo plazo da a quienes no lo hayan hecho para «que mostren la forma ab que ans de dita expulsió tenien poblats dits llochs»e informen de las gestiones realizadas y las dificultades encontradas para realizar la repoblación. Refiriéndose expresamente a los señores que pretendían no poder satisfacer el pago íntegro de los intereses de sus deudas, como es el caso de D. Francisco Joaquín Sanz, Fontanet ordenó

«que dins los matexos quinze dies presenten davant dit jutge comissari sos memorials en escrits, mostrant la forma en que ans de dita expulsió estaven dits llochs poblats, y declarant $\mathrm{si} \cdot 1 \mathrm{~s}$ tenien censits o a partició, y quanta era la de cada hu dels fruyts que en dits llochs y térmens se cullien, y lo que en effecte dits llochs cada any los valien; expresant també en los matexos memorials los béns, axí mobles com immobles, que han entrat en son poder que foren de les dites aljames o universitats y particulars moriscos expel-lits, y los càrrechs a que axí ells, com a possessors de dits llochs, com encara les dites aljames o universitats y los béns que foren de particulars moriscos expel-lits y han entrat en son poder, estan obligats».

Si además el señor solicitaba tasación de alimentos por su precaria situación económica, y en detrimento de los acreedores, debía presentar la documentación pertinente de cualquier otro ingreso y deuda; todo ello con mucha «puntualitat y legalitat». Contemplándose asimismo las penas correspondientes por el incumplimiento de las citadas disposiciones.

Ello nos lleva a una cuestión de fechas, y los acreedores pretenderán que no podrían aceptarse las pretensiones del señor porque el memorial se habría presentado fuera del plazo establecido, incurriendo en las penas contempladas en el pregón publicado por orden de Fontanet. D. Francisco Joaquín Sanz justificará la dilación por las fiebres que le habían afectado durante catorce meses, en otros momentos alargará la duración de la enfermedad hasta dos años, y una vida de retiro en Señera para atender los problemas de la repoblación. Pero ¿cuándo lo presentó? Y nos interesa determinarlo para algunas de las cuestiones que desarrollaremos después, pues ninguno de los memoriales está fechado. La carta puebla de 1445 la conocemos por un traslado del 10 de marzo de 1611 -realizado por orden del justicia de Játiva-, quienes confirman la veracidad de los informes de las rentas anteriores a la expulsión firman entre el 28 de febrero y el 3 de marzo de 1612 y los certificados notariales de los nuevos establecimientos son del 1 y el 5 de marzo del mismo año. Estos son los documentos que el señor acompaña en su petición, por lo cual debió presentarla en el mismo mes de marzo o poco más tarde, en cualquier caso antes de cosechar la hoja de morera, cuya recolección se realizaba a

9. Pascual Boronat y Barrachina: Los moriscos españoles y su expulsión. Estudio histórico-crítico. Imprenta de Francisco Vives y Mora, Valencia, 1901, vol. II, pp. 332-333 y 607-611. 
partir de los primeros días de abril y hasta fines de junio, ${ }^{10}$ pues en el memorial figura la partición a medias «por haver sido la partición antes de los nuevos establecimientos en los quales ha havido de dar la hoja a la tercera parte para el señor». "Por otro lado, los testigos de oficio declaran entre el 9 y el 22 de junio de 1612, y para entonces, como era habitual, se habrían presentado ya el memorial del señor y la contestación de los representantes de los acreedores, aunque no hagan mención explícita a los mismos.

\section{I.1.- Un tiempo, un lugar}

En estas páginas centraremos nuestra atención en los señoríos de Benemejís y Señera, aunque sólo esta segunda localidad haya llegado hasta nuestros días y Benemejís apenas se recuerda como un despoblado de su término del que apenas quedan restos. Me permito insistir en que hablamos de dos señoríos porque, en las pocas referencias a estos lugares en la bibliografía disponible, se suele hablar de Benemejís y Señera como de dos localidades pertenecientes a un mismo señorío, de forma explícita o implícita. Quizá haya sido decisivo en esa visión el tan conocido como citado testimonio de Gaspar Escolano, cuando, al describir los lugares del término de Játiva, menciona a «Benimixix y Seniera de don Francisco Sanz», ${ }^{12}$ y la obra de Escolano ha sido utilizada frecuentemente para trazar el mapa señorial valenciano a principios del siglo XVII. Y es correcto, pues cuando Escolano escribe su obra Benemejís y Señera pertenecían a un mismo señor, pero podemos hablar de una unidad circunstancial producto del juego, a veces caprichoso, de las estrategias matrimoniales y las herencias. Será una unión que se proyectará en el futuro, aunque por momentos pudo disolverse, y de hecho se disolvió por un corto período de tiempo; pero pensar en estas localidades como lugares de un mismo señorío haría que nos fuese todavía más confusa la interpretación de algunas situaciones que analizaremos, por más que nada en el expediente sustanciado ante D. Salvador Fontanet permita deducir que, en realidad, estemos ante dos señoríos.

Hoy en día, Señera es un municipio de la comarca de la Ribera Alta, actual provincia de Valencia, cuyo término, de apenas $205 \mathrm{Ha}$-que suponemos coincide aproximadamente con el de los dos antiguos señoríos-, es prácticamente llano y con una altitud que en poco supera la veintena de metros. Lindante con Villanueva de Castellón, Manuel y San Juan de Énova, está ubicado en la margen derecha del río Albaida, que baña su término por el $\mathrm{O}$ y el $\mathrm{S}$; río a cuyas aguas debe la fertilidad de sus tierras al mismo tiempo que suponía un peligro por sus avenidas, pasando a los anales como especialmente desastrosa la de 4 de noviembre de $1864^{13}$ hasta que otra mucho más reciente casi la ha hecho olvidar. Actualmente todas las tierras cultivables son de regadío y cabe hablar de

10. Tomàs PERIS Albentosa: Història de la Ribera. De vespres de les Germanies fins a la crisi de l'Antic Règim [segles XVI-XVIII]. Bromera, Alcira, 2001-2002, 3 vols, ver vol. II, p. 90.

11. AHN: Consejos, $22.243 / 4, \mathrm{ff}^{\circ} 8 \mathrm{r}^{\circ}$ y $13 \mathrm{r}^{\circ}$.

12. Gaspar ESCOLANO: Década primera de la historia de Valencia. Pedro Patricio Mey, Valencia, 1610-1611 (ed. facsímil reducida por el Departamento de Historia Moderna, Valencia, 1972), lib. IX, col. 1.200.

13. Vicente BoIX: Memoria histórica de la inundación de la Ribera de Valencia en los dias 4 y 5 de noviembre de 1864. Imp. de La Opinión, Valencia, 1865. Hay edición facsímil, Ed. Murta, Alcira, 1986. 
un monocultivo de cítricos, aunque todavía se guarda memoria de la importancia que tuvieron la morera y, hasta fechas mucho más recientes, los arrozales.

La pérdida de los registros parroquiales anteriores a 1869 hace que debamos recurrir, exclusivamente, a censos y vecindarios para conocer el volumen y la evolución de los efectivos humanos de estos lugares. Las primeras cifras de la época moderna las encontramos en el vecindario de $1510,{ }^{14}$ contamos después con las estimaciones de Jerónimo Muñoz, las del desarme de 1563, las del servicio extraordinario de 1602, ${ }^{15}$ los datos de un número importante de vecindarios generales de dispar significación, elaborados por las autoridades civiles en los siglos XVII y XVIII, y los de los primeros censos hispanos de la segunda mitad del Setecientos. ${ }^{16}$ A ellos debemos añadir las estadísticas eclesiásticas, siendo especialmente interesante la relación ad limina de 1622 , pues las posteriores repiten sistemáticamente los datos de Benemejís y Señera. ${ }^{17}$ Con carácter puramente local sólo contamos con las cifras que resultan del informe de rentas de $1609^{18}$ y otros que fecharemos en $1653 ;{ }^{19}$ la inestabilidad en la reocupación de estos lugares y las diferencias entre las fuentes hacen que renuncie a ofrecer sólo una

14. El resumen final de los datos locales ya fue publicado, pero sin desglosar las cifras de los lugares del término de Játiva, por Ricardo GARCía CÁRCEL: «El censo de 1510 y la población valenciana de la primera mitad del siglo XVI». Cuadernos de Geografia (Valencia), nº 18 (1976), pp. 49-66. Con posterioridad, se ha publicado la transcripción íntegra del manuscrito, en la cual se ofrece la enumeración de seis vecinos bajo el epigrafe «lo loch de Beninixix», pero no figuran los de Señera sino que, precediendo a la relación de Benemejís, aparece la de los vecinos de «lo loch de Cervera, qui és de don Ramon Sanç» (Rafael VALLDECABRES RODRIGO: El cens de 1510. Relació dels focs valencians ordenada per les corts de Montsó. Universitat de València, Valencia, 2002, p. 537). Se trata de un lamentable error de transcripción, pues en el documento original consta "Ceniera» y no Cervera (ARCHIVO DEL REINO DE VALENCIA (ARV): Real, 514 ter, $\mathrm{f}^{\circ} 431 \mathrm{r}^{\circ}$ ).

15. Para los vecindarios del siglo XVI, y hasta el de 1602, Henri LAPEYRE: Géographie de l'Espagne morisque. S.E.V.P.E.N., París, 1959 , pp. 38 y 40.

16. Salvo indicación en contrario, los datos de los vecindarios y censos de los siglos XVII y XVIII en Joan Serafí Bernat I MARTí y Miquel Àngel BADENES MARTín: Crecimiento de la población valenciana (1609-1857). Edicions Alfons el Magnànim, Valencia, 1994, pp. 140, 161, 180, 197, 215, 233, 251, 270 y 308. Con posterioridad se ha publicado el vecindario de 1703 por Carmen PÉREZ APARICIO: «El fogatge de 1703. Nuevos datos para la historia demográfica del País Valencianos. La población valenciana. Pasado, presente y futuro. Instituto de Cultura «Juan Gil-Albert»-Seminari d'Estudis sobre la Població del País Valencià, Alicante, 1998, vol. I, p. 78. De todas formas, hay que mantener serias reservas sobre las cifras de un vecindario que en más de la mitad de las ocasiones repite las de fuentes anteriores.

17. Primero estudió estas relaciones Ramón ROBREs LLUCH: «Catálogo y nuevas notas sobre las rectorías que fueron de moriscos en el arzobispado de Valencia y su repoblación (1527-1663)». Anthologica Anmua (Roma), vol. X (1962), pp. 185-191, los datos de Benemejis y Señera en pp. 162 y 177. Posteriormente ha visto la luz el conjunto de las relaciones de las diócesis valencianas, publicadas por $\mathrm{M}^{\mathrm{a}}$ Milagros CARCEL ORTÍ y Vicente CÁRCEL ORTÍ: Relaciones sobre el estado de las diócesis valencianas. Generalitat Valenciana, Valencia, 1989, 3 vols, vol. 1, pp. 233 y 243.

18. AHN: Consejos, 22.243/4, $\mathrm{ff}^{\circ} 3 \mathrm{v}^{\circ}$ y $9 \mathrm{v}^{\circ}$.

19. En una concordia de ese año entre el señor y sus acreedores (ARV: Manaments y empares $(M E), 1654$, libro 2, mano 14, ff' $27 \mathrm{r}^{\circ}-43 \mathrm{v}^{\circ}$ ). 
cifra en 1611 que podría llevar a engaño, ${ }^{20}$ pero lo que sí hay que decir es que ninguno de los dos lugares estaba despoblado en 1617, como alguna lectura errónea de la visita ad limina de ese año ha querido suponer.

\section{CUADRO I}

POBLACIÓN DE BENEMEIÍS Y SEÑERA EN LA EDAD MODERNA

\begin{tabular}{|c|c|c|c|c|c|c|c|c|c|}
\hline AÑO & $\begin{array}{l}1510 \\
(\mathrm{vec}) \\
\end{array}$ & $\begin{array}{l}1527 \\
\text { (vec) }\end{array}$ & $\begin{array}{l}1563 \\
(\mathrm{vec})\end{array}$ & $\begin{array}{l}1602 \\
\text { (vec) }\end{array}$ & $\begin{array}{l}1609-\mathrm{a} \\
\text { (vec) }\end{array}$ & $\begin{array}{c}1609-\mathrm{b} \\
(\mathrm{vec})\end{array}$ & $\begin{array}{l}1622 \\
\text { (vec) } \\
\end{array}$ & $\begin{array}{l}1646 \\
(\mathrm{vec})\end{array}$ & $\begin{array}{l}1653 \\
(\mathrm{vec})\end{array}$ \\
\hline SEÑERA & 25 & $27-28$ & 25 & 28 & 30 & 33 & 20 & 18 & 13 \\
\hline BENEMEJIS & 6 & 14- 15 & 24 & 27 & 24 & 30 & 7 & 3 & 1 \\
\hline AÑO & $\begin{array}{l}1692 \\
(\mathrm{vec})\end{array}$ & $\begin{array}{l}1703 \\
(\mathrm{vec})\end{array}$ & $\begin{array}{l}1712 \\
(\mathrm{vec})\end{array}$ & $\begin{array}{r}1730 \\
(\mathrm{vec}) \\
\end{array}$ & $\begin{array}{l}1768 \\
\text { (hab) }\end{array}$ & $\begin{array}{l}1783 \\
(\mathrm{vec})\end{array}$ & $\begin{array}{l}1786 \\
\text { (hab) }\end{array}$ & $\begin{array}{r}1794 \\
(\mathrm{vec}) \\
\end{array}$ & \\
\hline SEÑERA & 32 & 17 & 11 & 21 & 168 & 50 & 177 & 46 & \\
\hline BENEMEJÍS & $\mathrm{NC}$ & 3 & $\mathrm{NC}$ & $\mathrm{NC}$ & $\mathrm{NC}$ & 20 & $\mathrm{NC}$ & 0 & \\
\hline
\end{tabular}

1609-a: Vecindario de Caracena; 1609-b: informe señorial.

Fuentes: Véase notas 14 a 19.

Las estimaciones de población que nos ofrecen las citadas fuentes evidencian que estamos ante localidades de corto vecindario (Cuadro I). Las alternativas registradas son las habituales en la Valencia moderna, y no vamos a entrar en mayores detalles: un siglo XVI de importante crecimiento, culminando con un máximo de población que se alcanza en vísperas de la expulsión de los moriscos; las dificultades del Seiscientos, presididas por la forzosa partida de todos sus vecinos en 1609 y los problemas de la repoblación; un Siglo de las Luces de nuevo positivo, sin que podamos identificar cuándo se produjo el cambio de coyuntura, que lleva a que en Señera se supere el máximo alcanzado en 1609 , aunque no quepa decir otro tanto del conjunto de los señoríos estudiados. ${ }^{21}$

Ello nos lleva a la disparidad que observamos en la evolución registrada por ambas localidades. En el punto de partida, a principios del siglo XVI, el vecindario de Señera multiplica por cuatro el de Benemejís; cien años después, la diferencia se ha visto reducida de forma notable. Pero será la expulsión de los moriscos la que marque diferencias que serán definitivas: la reocupación de Benemejís fue pobre, menor que la de su vecina Señera como pone de manifiesto la relació ad limina de 1622, y la distancia se agudiza rápidamente sin que podamos ofrecer una explicación; el último dato

20. A beneficio de inventario, y por la repersusión que tendrá en la valoración de las consecuencias de la expulsión, podemos recoger los criterios de dos de los testigos de oficio presentados el 8 de junio de 1612: D. Acasi Sanz dirá que el vecindario habría quedado reducido a su tercera parte; Antoni Albert, más concreto, hablará de 18 ó 20 casas en Señera y 12 ó 13 en Benemejís (AHN: Consejos, 22.243/4, $\mathrm{ff}^{\mathrm{0}} 63 \mathrm{v}^{\circ}$ y $65 \mathrm{r}^{\circ}$ ).

21. Una visión de la evolución de los efectivos a escala comarcal a partir de censos y vecindarios en Tomàs Peris Albentosa: Història de la Ribera..., vol. I, pp. 173-174 y 234-235. 
de población disponible nos habla únicamente de tres vecinos en Benemejís en 1646, y una fuente quizás interesada menciona un solo vecino unos años después.

No podemos ofrecer datos posteriores, ni aceptar la cifra de 20 vecinos que da Castelló para $1783,{ }^{22}$ pues sabemos que Benemejís acabó antes como un despoblado. La primera noticia de ello nos la ofrece Cavanilles, quien, al hablar de los 46 vecinos de Señera, apunta que «en este número entran también los de Benimexix, agregada a Señera en 1773, por haberse destruido poco antes aquel pueblo, que nunca fue considerable»». ${ }^{23}$ No nos dice la causa de la despoblación el ilustrado botánico, aunque al hablar de localidades próximas como Señera y Villanueva de Castellón carga las tintas sobre los perjuicios del cultivo del arroz. Décadas después, Madoz será algo más explícito cuando dice que en Benemejís «únicamente se advierten algunos vestigios o cimientos de las casas que existieron. Atribúyese generalmente su despoblación a una epidemia que sufrió en el siglo pasado, en la que murieron muchos de sus vecinos; y los demás, para evitar semejante azote, se refugiaron en Semera $(s i c) \mathrm{V}$., donde formaron entonces la principal calle que todavía conserva el nombre de Benemegís». ${ }^{24}$ En nuestros días, Martí Soro atribuye la desaparición a una «espantosa» inundación acaecida en $1773^{25}$ y también se habla de paludismo. ${ }^{26}$ Consecuentemente, no figura Benemejís en el Nomenclátor de Floridablanca de $1785^{27}$ y consta como despoblado en la Noticia de Vicente Ignacio Franco. ${ }^{28}$

22. Ismael VALLÉS: «L'estimació de la població valenciana, segons el manuscrit de Josep Joaquim Castelló (1783)». En Carme PÉREZ APARICIO: Estudis sobre la població del Pais Valencià. Edicions Alfons el Magnànim-Seminari d'Estudis sobre la població del País Valencià, Valencia, 1988, vol. I, p. 129. El manuscrito de Castelló ha sido publicado después por Juan CoDinA: Descripción geográfica del Reyno de Valencia formada por corregimientos por Dn. Josef Castello, de la Real Academia de la Historia (1783). Diputació de Valéncia, Valencia, 2000; las referencias a Benemejís y Señera en p. 192.

23. Antonio José de CAVANilles: Observaciones sobre la historia natural, geografia, agricultura, población y frutos del reyno de Valencia. Imprenta Real, Madrid, 1795-1797 (ed. facsímil por Artes Gráficas Soler, Valencia, 1978), vol. I, p. 202.

24. Pascual MADOz: Diccionario geográfico-estadistico-histórico de España y sus posesiones de ultramar. Madrid, 1845-1860, vol. IV, p. 204.

25. José MARTí SORO: Historia de Villanueva de Castellón. Ayuntamiento de Villanueva de Castellón, Valencia, 1987 ( $2^{\mathrm{a}} \mathrm{ed}$ ), pp. 185-186. De todas formas fue, como dice el refrán, Salir del lodo y caer en el arroyo, pues en la gran riada de San Francisco (4 de octubre de 1779) «muy poco faltó para que también desapareciese Señera», según noticia del mismo autor.

26. Tomàs Peris Albentos A: Historia de la Ribera..., vol. 1, pp. 102, 110 y 192.

27. RELACIÓN de las ciudades, villas, lugares, aldeas, granjas, cotos redondos, cortijos y despoblados de España y sus islas adyacentes. Instituto Nacional de Estadística, Madrid, 1992, pp. 116-117.

28. Vicente IGnacio Franco: Noticia de la actual población del reyno de Valencia, la de sus despoblados desde la conquista por el rey don Jayme Primero, las leguas que distan de la capital, los señoríos directos que los poseen y las diócesis a que pertenecen. Oficina del Diario, Valencia, 1804 (hay ed. facsímil por Librerías «París-Valencia», Valencia, 1979), p. 30. 
En otro orden de cosas, Benemejís y Señera se ubican en una comarca de fuerte implantación señorial, ${ }^{29}$ siendo los señoríos de menor extensión de la Ribera. ${ }^{30}$ Por el nivel de sus rentas a principios del siglo XVII, antes de la expulsión de los moriscos, el señor estaba dentro del grupo de esos «más de ciento y veynte barones y señores de a dos mil, tres mil y quatro mil [libras] de renta» de que nos habla Escolano, ${ }^{31}$ grupo inmediatamente por debajo de los grandes señores y que tuvo una especial importancia en la dinámica social y política valenciana dado el temprano absentismo de éstos.

Más allá de su actual adscripción comarcal, en el terreno de la administración eclesiástica, Benemejís y Señera se escindieron en 1535 de Villanueva de Castellón, y en ambos casos la iglesia se dedicó a santa Ana. ${ }^{32}$ Pese a que Señera tuviese siempre un mayor vecindario y que su señor, Pedro Sanz, obtuviese licencia en 1433 para que se celebrase misa allí para consuelo espiritual de su familia y criados, la cabecera parroquial recayó en Benemejís y todavía en la relación ad limina de 1732 se habla de «Benimexix cum suo annexo Siniera»; $; 3$ el cambio de cabecera, impuesto por las circunstancias que conocemos, se produjo en fecha indeterminada. Sabemos de la visita de fray Bartolomé de los Ángeles, ${ }^{34}$ la nómina de sus párrocos durante unas décadas... ${ }^{35}$ y poco más.

En el terreno de la administración civil, Benemejís y Señera pertenecían a «los términos generales de Xátiva», como nos hace ver Viciana, quien, tras hablar de los pueblos en los cuales «Xátiva tiene señorío diferenciado», añade:

«En todos los otros pueblos la juridicción en el crimen pertenesce al justicia de la ciudad y en los cargos de cisas y en las fábricas e conservaciones de muros, valles o fossos de la ciudad todos los pueblos contribuyen en cierta cantidad repartida entre ellos por tassa. Y en lo demás destos pueblos los cavalleros que los posseen son señores delios y cogen las rentas y reciben otros aprovechamientos y usan de jurisdicción entre sus vassallos en las causas ceviles, según disposición de fuero del reyno». ${ }^{36}$

29. Una primera aproximación de carácter general en Sebastián GARCiA MARTiNEZ: «La Ribera desde las Germanias a la expulsión de los moriscos». En Economía Agrària i História Local. I Assemblea d'Història de la Ribera. Institució Alfons el Magnànim, Valencia, 1981, pp. 43-98. Mariano PEsET: «Propiedad y señorío en la Ribera del Júcar». En Economia agrària ..., pp. 99-159.

30. Tomàs Peris Albentosa: Història de la Ribera..., vol. III, pp. 147-153.

31. Gaspar ESCOLANO: Década primera..., lib. I, col. 210.

32. José SANCHIS SIverA: Nomenclátor geográfico-eclesiástico de los pueblos de la diócesis de Valencia. Tipografía Moderna, Valencia, 1922 (ed. facsímil por Librerías París-Valencia, Valencia, 1980), pp. 98 y 386.

33. Ma Milagros CÁrCel OrTí y Vicente CÁrCEL OrTí: Relaciones..., vol. II, p. 1.055.

34. Eliseo VIDAL BELTRÁN: «El cuaderno de un visitador de moriscos». Estudis (Valencia), $1^{\circ} 8$ (19791980), p. 63.

35. Ramón RoBRes LLUC:H: «Catálogo...», p. 163.

36. Martín de Viciana: Crónica de la inclita y coronada ciudad de Valencia. Valencia y Barcelona, 1564-1566 (ed. facsímil reducida, con estudio preliminar e índices de Sebastián GARCía MARTínEZ, Departamento de Historia Moderna, Valencia, 1972-1983), vol. III, p. 331. 
La escueta referencia de Viciana esconde toda una serie de situaciones diferentes entre sí y que podía suscitar, como suscitó, numerosos conflictos. No es un caso excepcional, se da en la generalidad de los municipios con extensos términos donde se encuentran señoríos de distinto tipo, ${ }^{37}$ y abarcan un buen número de cuestiones: delimitación de términos, jurisdicciones, percepción de distintos derechos económicos (sisas, peitas, ...), aprovechamientos comunales, riegos...

Aunque no entra en ello Viciana, hay que diferenciar un término general de otro particular, ${ }^{38}$ y es importante diferenciar si una localidad se ubicaba en uno u otro para definir los derechos de los residentes en ella y sus obligaciones respecto a la cabecera municipal. Las escuetas referencias documentales que da Sarthou apuntan a que Benemejís y Señera pertenecían al término particular de Játiva, aunque alguna vez utilice expresiones que pueden 1levar a confusión. ${ }^{39}$

En el término particular, sí, pero con una situación un tanto especial que cabe remontar a la concordia firmada en 1358 con Játiva por el «caballero» Pedro Sanz, señor de los lugares de Genovés, Alboy, Señera y Benemejís. ${ }^{40}$ Fue una concordia que equiparaba a estos lugares con los de caballería, lo cual hacía que quedasen exentos de una importante serie de derechos, entre los cuales destacaban las peitas y, sobre todo, las sisas; la única contribución que seguirían pagando a Xátiva, como postrer exponente de su dependencia, sería la de murs e valls. Esa situación de privilegio se refleja incluso en el vecindario de 1510 , donde tras hablar de la población del núcleo capitalino, de las alquerías de la huerta de la ciudad, de los lugares de los cuatro quarters, los vecinos de Benemejís y Señera se encuentran entre «los lochs del terme de la dita ciutat, qui són del pacte». ${ }^{41}$ De ahí, que en la documentación consultada siempre se diga que los señoríos de Benemejís y Señera se encuentran en el término general de Játiva, queriendo destacar que no tributan como los del término particular, y sólo de forma excepcional veremos en 1667 hablar de Señera como «situm et positum intra terminum particularem civitatis Setabis praedicte». ${ }^{42}$

Ello no fue óbice para que siguiesen dándose algunos conflictos. Unos porque podía faltar constancia en el cobro y hacer olvidar un derecho de escasa significación, y en 1624 Játiva debió recordar que, como en otros lugares, tenía la facultad de percibir 2 libras de Benemejís y 3 de Señera por murs e valls. Otros porque los señores de estos lugares pretendían estar exentos y que lo estuviesen sus vasallos de pagar las peitas

37. David BERNABÉ GLL: «Una coexistencia conflictiva: municipios realengos y señoríos de su contribución general en la Valencia foral». Revista de Historia Moderna (Alicante), n 12 (1993), pp. 11-77. Posteriormente, Francesc TORRES FAus: Evolució del mapa municipal valencià. La Xara. Simat de la Valldigna, 1999, pp. 118-126.

38. Francesc TORRES FAUS: Evolució..., pp. 116-118.

39. Carlos Sarthou Carreres: Datos para la historia de Játiva. Játiva Turista, Játiva, 1933, pp. 103, 13 l$132,134,408$ y 412.

40. Carlos Sarthou Carreres: Datos..., p. 132.

41. Rafael VALLDECABRES RODRIGO: El cens de $1510 \ldots$, pp. 535 y ss.

42. ARV: Protocolos de Domingo Trobat, 1667, sig. 10.373, $\mathrm{f}^{\circ} 195 \mathrm{v}^{\circ}$. 
debidas por las tierras que poseían en términos vecinos. ${ }^{43}$ También tuvieron pleitos por términos, aunque no con Játiva sino con Villanueva de Castellón cuando en 1587 obtuvo el título de villa y se segregó de la ciudad, discutiéndose entonces la adscripción de determinadas partidas rurales. ${ }^{44}$

Tenemos asimismo noticias de conflictos sobre el perfil jurisdiccional de estos señoríos. La oposición que hace Viciana entre «la juridicción en el crimen [que] pertenesce al justicia de la ciudad» y la de los señores de los lugares del término que «usan de jurisdicción entre sus vassallos en las causas ceviles, según disposición de fuero del reyno $\gg,{ }^{45}$ se presta a confusión, pues en la documentación e incluso en juristas de tanto prestigio como Lorenzo Mateu se tiende a hablar de jurisdicción civil al referirse a la alfonsina, por más que ésta incluya una baja criminal, inducidos por el mismo título del fuero que primero reguló este nivel de competencias jurisdiccionales: De juredictió atorgada a aquells qui no han mer imperi. ${ }^{46}$

En la larga batalla librada por Játiva con los señoríos comprendidos en su término, las competencias jurisdiccionales de los señores están presentes a menudo, y es un tema que sería interesante estudiar con detenimiento. ${ }^{47}$ El conflicto es antiguo y, por lo que aquí nos interesa, ya en las cortes de 1437-1438 se presentó un greuge «por la intromisión del gobernador en la jurisdicción criminal de Pere Sanç, señor de Senyera, en términos de la villa de Xàtiva» ${ }^{48}$ y si el agravio era por lesionar la jurisdicción criminal del señor, era que éste pretendía al menos la alfonsina. Pero el conflicto se prolonga mucho en el tiempo y llega incluso más allá de la abolición del derecho foral. Sarthou cita las sucesivas sentencias de la Real Audiencia favorables a la ciudad en contenciosos con Señera pronunciadas a lo largo del siglo XVII, ${ }^{49}$ aunque no se detiene en sus contenidos ni su escueta cita permite dilucidar si también afectan a Benemejís.

El caso es que, de forma continuada, los sucesivos señores de Benemejís y Señera se declararán titulares de la jurisdicción alfonsina; quizás los del segundo lugar aspirasen a algo más. Por no acumular citas, recojamos sólo unos documentos que encuadran el período que nos interesa: en 1574 D. Onofre Benito Sans carga un censal sobre Benemejis, con sus hornos, derechos, «jurisdictionemque tam civili quam criminali»; ${ }^{50}$

43. Carlos Sarthou Carreres: Datos..., pp. 138-139 y 413.

44. Francesc TORREs Faus: Evolució..., p. 92.

45. Martín de Viciana: Crónica de la ínclita..., vol. III, p. 331.

46. Primitivo J. PLA ALBEROLA: «La jurisdicción alfonsina como aliciente para la recolonización del territorio». Revista de Historia Moderna (Alicante), n 12 (1993), pp. 79-82.

47. Adelantada la redacción de este trabajo, he tenido noticia de la próxima publicación de una Historia de Játiva, cuyo volumen dedicado a la Edad Moderna está coordinado por Pablo Pérez Garcia, a quien agradezco que me haya facilitado la consulta de los capítulos que él dedica a estas cuestiones y que suponen un análisis claro y preciso de un tema tan complejo.

48. Carlos López Rodríguez: Nobleza y poder politico en el reino de Valencia (1416-1446). Universitat de València, Valencia, 2005, p. 314.

49. Carlos Sarthou Carreres: Datos..., p. 414.

50. ARV: $M E, 1703$, lib. 3, mano $35, \mathrm{ff}^{\circ} 18 \mathrm{r}^{\circ}-20 \mathrm{r}^{\circ}$. 
cuando en 1667 D. Agustín Sanz de la Llosa dona el lugar de Señera a su hermano D. Francisco Sanz de la Llosa y Alboy, hasta entonces sólo señor de Benemejís, lo hace «cum jurisdictione civili et criminali nuncupata alfonsina et quam dominus dicti loci juxta Foros et privilegia presentis regni habet»; ${ }^{51}$ en una donación propter nupcias de 1698 se habla del lugar de Benemejís, en los términos generales de Játiva, «ab la jurisdicció alfonsina y ab tots los demés drets dominicals»; del de Señera, en el mismo término general, «així mateix ab la jurisdicció alfonsina y tots los demés drets dominicals»). .2

En las cartas pueblas firmadas tras la expulsión de los moriscos, que luego analizaremos, falta una alusión expresa al nivel de competencias jurisdiccionales que posee el entonces señor de ambos lugares; puede entenderse que no quiera alimentar conflictos con Játiva sobre la jurisdicción alfonsina, pero también que no quiera que en un documento de esa trascendencia figure una referencia explícita a que sólo poseía ese nivel de competencias, pues podría obrar en su contra con posterioridad. En ellas se contempla la facultad señorial de imponer penas a quienes incumplan lo acordado en las cartas pueblas, de promulgar las disposiciones convenientes para el gobierno de las dos localidades con las correspondientes «penes, així corporals com pecuniàries,» y la reserva por el señor de «tota jurisdictió, així civil com criminal» que por Fueros le pertenezca. ${ }^{53}$

En el terreno de la práctica, desconozco actuaciones concretas de los distintos señores que permitan dilucidar el nivel de sus competencias jurisdiccionales. Apenas puedo apuntar que, cuando se arriendan los señoríos, ceden a los arrendatarios jurisdicción suficiente para el cobro de las rentas como es habitual en este tipo de contratos: en 1584 el señor de Benemejís «se retura tota la jurisdictió», cediendo a los arrendatarios «jurisdictió de deu sous per a cobrar y fer procurar» y «jurisdictió per a que poguen executar al que $s$ trobarà de dia o de nit en pena de sexanta sous»; $;{ }^{54}$ en el de Benemejís y Señera de 1618, el señor transfiere a los arrendatarios los clams, la capacidad de mandar a los vasallos «fer alguna cosa nesessària ho menesterosa», o hacerla a su cargo, y «poder amplísim» para cobrar los derechos regalianos sin auxilio de la justicia señorial. ${ }^{55}$ Como actuaciones en el terreno de la administración de justicia, sólo conocemos las denunciadas como extorsiones realizadas por el señor, a principios del siglo XVII, para forzar a que sus vasallos abandonasen los pleitos que llevaban contra él: el castillo de Benemejís era utilizado como cárcel y en Señera existía cepo, símbolo de la jurisdicción alfonsina. ${ }^{56}$

51. ARV: Protocolos de Domingo Trobat, 1667, sig. 10.373, $\mathrm{ff}^{\circ} 195 \mathrm{v}^{\circ}-196 \mathrm{r}^{\circ}$. No hay elementos significativos en la inmediata toma de posesión.

52. ARV: $M E, 1698$, lib. 3, mano $32, \mathrm{ff}^{\circ} 45 \mathrm{r}^{\circ}$ y ss.

53. Véase la carta puebla transcrita en el apéndice, cap. 27.

54. ARV: Real Audiencia, Procesos, 1/A/421, sin foliar, cap 9.

55. ARV: Real Audiencia, Procesos, 1/F/1.256, $\mathrm{f}^{\circ} 54 \mathrm{r}^{\circ}$, caps. 5-7.

56. ARV: Real Audiencia, Procesos, 1/S/1.660. 


\section{2.- Los Sanz, «linage militar de Xátiva»}

También debemos preguntarnos por los señores, aunque aquí no sea cuestión más que de esbozar unas breves pinceladas que nos permitan ubicarlos en la sociedad del momento. Cuando se produjo la expulsión de los moriscos y la firma de las inmediatas cartas pueblas era señor de Benemejís y Señera D. Francisco Joaquín Sanz, residente en Játiva. Ante la insinuación de los representantes de los acreedores de que sería injusta la minoración de las deudas a quien, quizás, se había endeudado precisamente para adquirir sus señoríos, D. Francisco respondió de forma tajante:

«Se niega expresamente que dicho don Françisco responda censales algunos del precio de los mesmos lugares ni menos de tierras agregadas a ellos, pues de tiempos de la conquista asta ahora dichos lugares son de su familia y ascendencia por donación echa a don Pedro Sans, ascendiente de dicho don Francisco, por el rey don Jayme el Primero de Aragón, en remuneración de los muchos cervicios que le hiso en la conquista del reyno». ${ }^{57}$

Los Sanz eran conscientes de la antigüedad de su linaje y se preciaban de su contribución a la conquista del reino. Las crónicas nos hablan de la vinculación de esta familia con Játiva desde tiempos de la conquista por Jaime I, y que los Sanz que acompañaron al Conquistador, según Viciana, «no fueron mal heredados, porque hasta hoy vemos que los cavalleros del apellido de Sans en Xátiva possehen todo lo bueno y mejor della». ${ }^{58}$ Coincide con él Escolano:

«Pedro Sanz fue uno de los juezes repartidores de las tierras en el año mil docientos quarenta y quatro, como parece por el libro que se guarda en el archivo de Xátiva; y a él y sus decendientes les cupo tan grande parte y tal en la huerta de Xátiva que no se les yguala ningún otro linage de los heredados en ella. Entre otros heredamientos que tuvo el Pedro Sanz, fue el lugar de Seniera (...) que se conserva hasta el día de hoy en su casa y descendencia»r. ${ }^{59}$

Señera aparece así casi como la casa solar de los Sanz en el reino de Valencia, pero su patrimonio es mucho más importante en Játiva y son titulares de distintos señoríos en su dilatado término, aparte de sus posesiones en otras comarcas y reinos. Efectivamente, al enumerar los señoríos del término de Játiva, Viciana atribuye diez a señores apellidados Sans, con distintas variantes ortográficas, ${ }^{60}$ aunque la nómina que ofrece Escolano es notablemente menor. ${ }^{61}$

Escolano dirá que el linaje de «los Sanzes (...) es de los más estendidos del reyno y que más heredamientos tienen en él» ${ }^{62}$ por ello se impone la progresiva diferenciación de distintas ramas - pero sin olvidar su procedencia de un tronco común-- a menudo al integrar en sus apellidos el nombre del lugar del que eran señores o lo era

57. AHN: Consejos, 22.243/4, $\mathrm{f}^{\circ} 68 \mathrm{r}^{\circ}$.

58. Martín de Viciana: Crónica..., vol. II, p. 151.

59. Gaspar Escolano: Década primera..., lib. IX, col. 1.105.

60. Martín de VICIANA: Crónica..., vol. III, pp. 330-331.

61. Gaspar EsCOLANO: Década primera..., lib. IX, cols. 1.174 y 1.200-1.201.

62. Gaspar Escolano: Década primera..., lib. IX, col. 1.104. 
un miembro de su familia, como los Sanz de Alboy, Sanz de Corbera, Sanz de Lloris, Sanz de la Llosa o Sanz de Tallada, hablándose también de los Sanz de Señera desde fines del siglo XVI o de los Sanz de Benemejís. Ramas entre las cuales se teje una tupida red de alianzas, de forma que sin un estudio más detallado es inviable establecer los vínculos de parentesco existentes entre sus miembros y, en ocasiones, incluso identificar correctamente a alguno de ellos, por lo cual quedan muchos cabos sueltos por atar y piezas por encajar.

Conocemos algunos señores de Benemejís y Señera durante la baja edad media y primeros tiempos de la moderna, tanto de ambos lugares como sólo de uno de ellos, sin que podamos entrar en una genealogía pormenorizada que costaría trabajo documentar con detalle. ${ }^{63}$ Sabemos de un Pedro Sanz, caballero, que era señor en 1348 de los lugares de Alboy, Benemejís, Genovés y Señera. Ese patrimonio se disgregó posteriormente y en 1430 encontramos a un Bernat Ramón Sanz, caballero, como señor de Benemejís y en 1437 a Pere Sanz como señor de Señera. ${ }^{64}$ Tenemos noticias de posteriores señores de estos lugares, alguno de los cuales alcanzaría un cierto relieve político, caso del «multus magnificus Francisco Ludovicus Bou, militi, gubernatori regni Valencie extra rivum Xucaris, domino loci seu alquaree bocate Benimixis, situati seu situate intra generales terminos civitatis Xative» ${ }^{65}$ Por entonces, fines del siglo XV, era titular de Señera Pedro Sanz, el cual testó en Señera el 19 de febrero de 1485 y fue enterrado unos días después en la capilla de San Juan en la Colegiata de Játiva, capilla «dita vulgarment dels Sanços»; le sucedió su hijo Perot Sanz, quien un año antes había contraído matrimonio con su prima D. ${ }^{a}$ Aldonza Tolsá, ${ }^{66}$ ya viuda en 1510.

Les siguen en el señorío de Benemejís D. Francisco Sanz, antes señor de Montichelvo, quien ya aparece así en un documento de $1522^{67}$ y cuyo testamento se publicó el 14 de mayo de 1557, y en el de Señera D. Ramón Sanz. Así hasta conectar con la obra de Viciana, quien, entre los lugares del término de Játiva, habla de «Seniera de Sans, Benimexix de Sans», sin identificar con mayor precisión a los titulares, de forma que podía pensarse en una misma persona. Pero no es así, según consta al hablar de los miembros de esta familia, pues D. Onofre Sanz es el señor de Benemejís y D. Ramón Sanz es el de Señera. ${ }^{68}$ A mediados del siglo XVI continuamos con dos señoríos

63. Salvo indicación en contrario, las referencias a esta familia proceden de las anotaciones contenidas en los libros de la colegiata de Játiva, donde se registran la constitución y posteriores transmisiones de los censales que percibe la institución. Para la localización de las referencias que nos interesaban ha sido fundamental el tíchero de D. Luis Cerveró. ARV: Clero, lib. 1.191, ff $83 \mathrm{v}^{\circ}, 103 \mathrm{v}^{\circ}, 108 \mathrm{r}^{\prime \prime}, 110 \mathrm{r}^{\circ}, 191$ $\mathrm{v}^{\circ}, 199 \mathrm{r}^{\circ}, 204 \mathrm{r}^{\prime \prime}$ y $207 \mathrm{v}^{\circ}$; ibid., lib. 2.275, fo 142; ibid., lib.3.015, fo $13 \mathrm{r}^{\circ}$; ibid., lib. 3.157 , $\mathrm{f}^{\circ} 12 \mathrm{v}^{\circ}$; ibid., lib. $3.175, \mathrm{f}^{\circ} 18 \mathrm{v}^{\circ}, 40 \mathrm{r}^{\circ}, 90 \mathrm{r}^{\circ}, 121 \mathrm{v}^{\circ}, 197 \mathrm{r}^{\circ}, 199 \mathrm{v}^{\circ}, 204 \mathrm{v}^{\circ}, 243 \mathrm{v}^{\circ}, 249 \mathrm{v}^{\circ}$ y $254 \mathrm{r}^{\circ}$; ibid. lib. 3.256, $\mathrm{f}^{\circ}$ $163 \mathrm{r}^{\circ}$; e ibid. lib. $3.756, \mathrm{ff}^{\mathrm{o}} 1.97 \mathrm{r}^{\circ}, 240 \mathrm{r}^{\circ}, 287 \mathrm{r}^{\circ}, 354 \mathrm{r}^{\circ}, 436 \mathrm{v}^{\circ}$ y $437 \mathrm{r}^{\circ}$.

64. Carlos López Rodríguez: Nobleza y poder político..., pp. 165 y 314.

65. ARV: Bailia, libros, $\mathrm{n}^{\circ} 218, \mathrm{ff}^{\circ} 303 \mathrm{r}^{\circ}-304 \mathrm{r}^{\circ}$ (14 de septiembre de 1486).

66. Archivo del Colegio del Patriarca, Valencia (ACP): Protocolos de Luis Saranyana, año 1484, sig. 25.588, sin foliar, escra. de 15 de noviembre.

67. Martín de VICIANa: Crónica..., vol. IV, p. 442.

68. Martín de VICIANA: Crónica..., vol. II, p. 150 y vol. III, pp. 330-331. 
independientes, sobre los cuales se constituyen dos vínculos asimismo independientes, el que poseía D. Francisco Gaspar Sanz, señor de Benemejís, y D. Joan Sanz, señor de Señera; pero estamos en vísperas de la unión de ambos señoríos bajo un solo titular.

En su testamento de 1557, D. Francisco Sanz aparece sólo como señor de Benemejís; pero poco después, en 1563, cuando se procede al desarme de los moriscos del reino, ambos señoríos pertenecerán a D. Onofre Benito Sanz, ${ }^{69}$ hijo y heredero del anterior. ${ }^{70}$ No he podido fijar la fecha ni las razones de tal anexión; las noticias espigadas me hacen suponer que la hija de D. Ramón Sanz -D. ${ }^{a}$ Ana, que a veces aparece como Sanz de Lloris, por el apellido de su madre, o como Sanz de Sanz- aportó como dote el lugar de Señera en su matrimonio con D. Onofre Benito Sanz . Durante unos años veremos aparecer un único titular de ambos señoríos, el citado D. Onofre, y esperaba que sucediese directamente en ellos el firmante de las cartas pueblas. De ahí mi sorpresa cuando de nuevo me encuentro con señores independientes, D. Onofre y D." Ana. La explicación es que se había disuelto económicamente el matrimonio, al tener D. Onofre que devolver la dote a su mujer y, con ella, el lugar de Señera. ${ }^{71}$ Desde entonces D. Ana Sanz aparecerá como su señora y D. Onofre Sanz como el de Benemejís, hasta que un nuevo señor de este lugar, D. Pedro Sanz, figure como señor de Benemejís en 1590 al contraer matrimonio con Elisabet Ferrer. Debía ser menor, pues en 1595 todavía está bajo la tutela de su madre, D. ${ }^{a}$ Ana Sanz de Lloris, y quizás morir pronto. Ésta, en su último testamento de 28 de agosto de 1597 deja a su otro hijo, D. Francisco Joaquín Sanz, el señorío de Señera y en 1604 se titula también señor de Benemejís.

D. Francisco Joaquín Sanz era el señor de Benemejís y Señera cuando se produjo la expulsión de los moriscos, y de él pocas noticias más podemos aportar. Hijo de D. ${ }^{a}$ Ana Sanz y D. Onofre Benet Sanz, debió nacer en 1581 ó 1582, pues al declarar como testigo el 13 de marzo de 1620 decía tener 39 años, poco más o menos $;{ }^{72}$ asistió a las cortes de 1604, donde figura con el apellido Sans de Senyera junto a D. Cristòfol y D. Joan ${ }^{73}$; contrajo matrimonio con D. ${ }^{a}$ María Castellví, hija de D. Felipe Castellví, caballero ya fallecido, y D. Juana Ribot, según capítulos matrimoniales de 27 de abril de $1604 ; ;^{74}$ al final de sus días lo vemos como presbítero, desconociendo cuándo se ordenó, y con residencia en la parroquia de San Esteban de Valencia. Ya en su lecho de muerte, testó el 9 de marzo de 1630, añadiendo un codicilo dos días después, que, tras su fallecimiento, fueron publicados el 14 del mismo mes y, a continuación, su cuerpo

69. Manuel DANVILA y COLLADO: «Desarme de los moriscos en 1563». Boletín de la Real Academia de la Historia (Madrid), vol. X (1887), pp. 295 y 303

70. ARV: $M E, 1703$, lib. 3, mano $35, \mathrm{ff}^{\circ} 18 \mathrm{r}^{\circ}-20 \mathrm{r}^{\circ}$.

71. ARV: Real Audiencia, Procesos, 1/A/421. El proceso se alarga entre marzo de 1586 y mayo de 1588 , pero desconozco la sentencia,

72. ARV: Real Audiencia, Procesos, 1/F/1.256, $1^{\circ} 12 \mathrm{v}^{\circ}$.

73. $\mathrm{M}^{\mathrm{a}}$ Llü̈sa MUÑoz ALTABERT: Les Corts valencianes de Felipe III. Universitat de Valènciá, Valencia, 2005, p. 96.

74. AHN: Consejos. 22.243/4, ffo $85 r^{\circ}-86 r^{\circ}$. 
llevado a enterrar a la Colegiata de Játiva, «en lo vas en aquella instituhit en la capella dita dels Sans de Senyera $>^{75}$.

En el citado testamento, aparte de unos pocos y pobres legados - con diferencia el más generoso es el de 100 libras al Hospital General de Valencia ${ }^{76}$, de dejar por su alma 200 libras y de la declaración casi formularia de que se pagasen todas sus deudas, dispuso sobre el destino de sus bienes, distinguiendo entre los libres y los vinculados. Entre los primeros sólo se mencionan los que habían pertenecido a su hija, ya fallecida, D. ${ }^{a}$ María -Ana María en otros documentos-, cuya cuantía y composición desconocemos, y de los cuales dejaba heredero a su hermano D. Juan Sanz de Señera, de forma vitalicia y con la condición de que dispusiese a favor de sus hijos D. Francisco y D. ${ }^{a}$ Luisa Sanz de Señera cuando alcanzasen los 22 años, con matices en los que no podemos detenernos. Los bienes vinculados los dejaba también a su hermano D. Juan y, de morir éste sin hijos, a D. Jerónimo Sanz de la Llosa, hijo mayor de se su hermana $D .{ }^{a}$ Magdalena, ya fallecida. Unas decisiones que no dejan de sorprendernos por varios motivos, ¿disponer de unos bienes vinculados? D. Juan Sanz de Señera protestará cuando se publique el testamento que esa disposición no le causase perjuicio como heredero en el vínculo; ¿por qué no a favor de esos «fills meus naturals molt amats en menor edat constituhits?» quizás porque eran naturales, pero no legitimos, $\mathrm{y}$, por lo tanto, excluidos de la sucesión en los bienes vinculados. D. Juan también aceptará los bienes libres a beneficio de inventario.

El caso es que D. Juan Sanz de Señera fue el titular de ambos señoríos durante largos años hasta que, ya de avanzada edad, el 8 de diciembre de 1666, donó los señoríos de Benemejís y Señera, respectivamente, a sus sobrinos D. Francisco y D. Agustín Sanz de la Llosa. Son los últimos y efímeros.momentos de vida como señoríos independientes, pues el 5 de marzo de 1667 D. Agustín Sanz de la Llosa, caballero del hábito de San Juan de Jerusalén, señor de Señera y residente en Játiva, donó a su hermano D. Francisco Sanz de la Llosa y Alboy, señor de Benemejís y también residente en Játiva, el señorío de Señera con todos sus derechos y determinadas condiciones, sobre todo en previsión de conflictos sobre los censales que gravaban el lugar. ${ }^{77}$

Así hasta llegar a principios del siglo XVIII, cuando el noble D. Jacinto Forner Sanz de la Llosa y Alboy, residente en Valencia, se titula barón de Cotes, Arraval, Finestrat, Cortes, Boxet, Roaya, señor del castillo de Chirel y de los lugares de

75. ACP: Protocolos de Antoni Valls, 1630, sig. 27.547, sin foliar, escras. de 9 (testamento) y 11 de marzo (codicilo).

76. En el codicilo, en cambio, quizás queriendo resolver un problema de conciencia, legó a Rafaela Romana una pensión vitalicia de 20 libras anuales.

77. ARV: Protocolos de Domingo Trobat, 1667, sig. 10.373, $\mathrm{ff}^{\circ} 194 \mathrm{v}^{\circ}-206 \mathrm{r}^{\circ}$. Le siguen las donaciones que, en compensación, hace D. Francisco Sanz de la Llosa y Alboy, titulándose ya señor de Benemejís y Señera, a su hermano D. Agustín Sanz de la Llosa (ibíd., $\mathrm{ff}^{\mathrm{D}} 206 \mathrm{r}^{\circ}-223 \mathrm{r}^{\circ}$ ), y la toma de posesión de Señera (ibid. $\mathrm{ff}^{\circ} 223 \mathrm{r}^{\circ}-231 \mathrm{r}^{\circ}$ ). En la documentación consultada, ya siempre pertenecerán a un mismo titular ambos señoríos, que se integrarán en un patrimonio cada vez más amplio por el albur de la biología y el cálculo de las estrategias matrimoniales seguidas por esas familias. 
Benasáu, Benemejís, Señera, Ayacor y Agost. ${ }^{78}$ Nacido en Alicante en 1677, era señor de Cortes y Agost por su matrimonio con Josefa Pallás de Vallebrera, pero los señoríos de Benemejís y Señera se los donó en contemplación de matrimonio ${ }^{7 \%}$ su madre D. ${ }^{a}$ Josefa Sanz de la Llosa, Alboy, Señera y Monsoriu. ${ }^{80}$ Ésta, nacida en Játiva en 1649, había contraído matrimonio con D. Alejandro Forner y Talayero, miembro de una familia que había tenido un reciente y rápido encumbramiento: su padre, D. Jacinto Forner -hijo de un mercader- nació en 1620, fue nombrado caballero en 1651, obtuvo el Privilegio de Nobleza con voto en Cortes en 1669, adquirió primero el señorío de Benasáu y, después, la baronía de Finestrat en 1674, de la cual tomó posesión el 27 de diciembre de $1675 .{ }^{81}$

D. Jacinto murió sin sucesión, pero sus herederos alcanzaron el título de marqués de Benemejís, concedido en 1757 ó 1762, según las fuentes, a D. ${ }^{a}$ Mariana de Tárrega y Sanz de la Llosa, con la grandeza de España ya un siglo después. ${ }^{82}$

\section{II.- LOS SEÑORÍOS EN VÍSPERAS DE LA EXPULSIÓN}

El siglo XVI está considerado como un período de crecimiento y transformaciones importantes que no podían menos que repercutir en los señoríos, en la evolución de sus rentas y su misma estructura. Se habla del crecimiento de las rentas señoriales, de su diferente evolución según el peso relativo que en las mismas tuviesen los derechos de monopolio, los censos fijos en dinero o las particiones de frutos; de las modificaciones, muchas o más bien pocas, que supusieron la forzosa conversión de los mudéjares al cristianismo o el creciente intervencionismo del poder monárquico en detrimento de cualquier otra instancia jurídico-política en el interior del reino.

Todas ellas son cuestiones muy debatidas y sobre las cuales nada podemos aportar porque la documentación disponible apenas nos permite aproximarnos a la instantánea de la situación inmediatamente anterior a la expulsión de los moriscos, y con su cara y su cruz: si hablaremos de los ingresos de unos modestos señoríos, también nos inte-

78. Archivo Municipal de Novelda (AMN): Protocolos de Jusep Sirera y de la Torre, 1707-1708, sin foliar, escra. de 23 de diciembre de 1708 .

79. ARV: $M E, 1698$, lib. 3, mano $32, \mathrm{ff}^{\circ} 43 \mathrm{r}^{\circ}-48 \mathrm{v}^{\circ}$, sigue en mano $33 \mathrm{ff}^{\circ} 1 \mathrm{r}^{\circ}-2 \mathrm{r}^{\circ}$.

80. Sobre la solución de los conflictos que mantuvo ésta con sus familiares véase ARV: $M E, 1696$, lib. 3, mano $28, \mathrm{ff}^{\circ} 2 \mathrm{r}^{\circ}-16 \mathrm{v}^{\circ}$.

81. Noticias sobre estas familias en Agustín de ARQUES JOVER: Nobiliario alicantino (Ed. de Luis MAS y Gil y José $M^{2}$ Esquerdo Ribera). Publicaciones de la Comisión de Cultura del Excmo. Ayuntamiento de Alicante, Alicante, 1966, p. 52. Luis MAS Y GIL: Toponimia alicantina en la nobiliaria española. Instituto de Estudios Alicantinos, Alicante, 1976, pp. 107-108. Barón de FINESTRAT: Nobiliario alicantino. Instituto de Estudios Alicantinos, Alicante, 1983, pp. 139-144.

82. Julio de ATIENZA: Nobiliario español. Diccionario heráldico de apellidos españoles y de títulos nobiliarios. M. Aguilar ed. Madrid, 1948, p. 1.389. Ampelio Alonso de CADENAS y LóPEZ y Vicente de CADENAS y VICENT: Elenco de grandeza y titulos nobiliarios españoles. Hidalguía, Madrid, $1998\left(31^{\text {a }}\right.$ ed.), p. 164 . 
resaremos por las deudas que gravaban los ingresos del señor, las cuales podían hacer que el balance resultase a menudo muy comprometido.

Ahora bien, esos crecimiento y transformaciones originaron frecuentes tensiones entre señores y vasallos que, a menudo, se habían resuelto tradicionalmente con la huida de los primeros $y$, en unos pocos casos, con el recurso a las armas. El fortalecimiento del poder real abrió de forma progresiva otra vía hasta entonces prácticamente inédita, pues su utilización era costosa y arrięsgada: la judicial ante una instancia supuestamente neutral. Desde que en 1581 el Supremo Consejo de Aragón dictaminó que el conocimiento de las causas que afectaban a una universitat, como demandante o como demandada, eran privativas de la justicia regia, y aún más desde que en las cortes de 1585 se contempló el recurso de manifiesta opresión contra las decisiones de los barones valencianos, los conflictos que enfrentaban a los señores y sus vasallos, por las cuestiones más dispares, fueron introducidas en cascada en los tribunales del rey. ${ }^{33}$

Los procesos ante la Real Audiencia se multiplicaron en el último cuarto del siglo XVI y primeros años de la siguiente centuria, generando un importante volumen de documentación que nos permite adentrarnos mejor en los conflictos de la época. En los señoríos que nos ocupan, el más importante del que nos ha llegado noticia gira en torno a la exigencia de los servicios personales en Benemejís. Unos servicios en los cuales el señor parecía muy interesado y que los vasallos moriscos se resistían a prestar.

Aunque se hable de varias causas todas están íntimamente relacionadas y, en la medida que podemos reconstruirlo, el proceso tiene un corto desarrollo. Iniciado por parte del síndico de Benemejís el 16 de diciembre de 1603 ante el llochtinent de portantveus de general governador de Játiva, con la correspondiente contrafirma presentada por el señor unos días después, al poco pasó al portantveus de general governador de Valencia, quien dictó sentencia el 25 de agosto de 1604. Declaraba en ella la manutenencia del señor en la percepción de unos servicios que habían quedado probados por testigos. La causa se introdujo después en la Real Audiencia, y es en las instancias presentadas ante este tribunal donde mejor podemos conocer las diferencias entre las partes. ${ }^{84}$

En la versión del síndico de Benemejís, el señor habría presionado a los vasallos para que prestasen «certs pretés servici eo tandes dites vulgarment de braços y de fadrins» o «jornals de braços y viatjes de fadrins». En la medida que conocemos algunos ejemplos concretos, el señor podía mandar a un vasallo que labrase sus higueras o a otro que le trajese de Játiva dos toneles o una guitarra, claro está que sin ninguna remuneración. Si se negaban a prestarlos, imponía multas o penas de prisión que conmutaba

83. Primitivo J. Pla Alberola: «Causas reservadas a la justicia regia e inmunidad de las baronías: "las causas consistoriales'》. En Esteban SARAsa SÁnchez y Eliseo Derrano Martín (Eds.): Señorio y feudalismo..., vol. II, pp. 475-509. Con carácter más general, del mismo autor, «El desmantelamiento del poder politico de los señores valencianos en los siglos XVI y XVII». En Enrique MARTínez RUIZ y Magdalena de Pazzis PI CORRAles (Dirs.): España y Suecia en la época del barroco (16001660). Comunidad Autónoma de Madrid-Encuentros Históricos España-Suecia, Madrid 1998, pp. 73-99.

84. ARV: Real Audiencia, Procesos, 1/S/1.660. 
a veces por el compromiso del vasallo de realizar esos trabajos. Cuando la cuestión se planteó ante los tribunales del rey, el señor intentó frenar el desarrollo de la causa prohibiendo al síndico que fuese a Játiva o desaconsejando a los demás vasallos, a quienes reunió en la iglesia, la prosecución de la causa y consiguiendo que algunos se negasen a pagar los repartos vecinales aprobados por el consell para sufragar los gastos.

Podríamos deducir que un joven señor, pues D. Francisco tendría unos 22 años y poco antes tomado posesión del señorío, habría querido actualizar viejos derechos para hacerlo más rentable, sobre todo si atravesaba por dificultades económicas. Es una situación que documentamos en otros lugares, pero aquí esa explicación no resulta convincente a la luz del arrendamiento de las rentas de Benemejís en 1584. En él acordaron señor y arrendatarios que éstos «no puixen pendre més de cent y cinquanta jornals per tanda per a fer faena», mientras el señor «se retura la tanda de portar la roba a Xàtiva, juntament ab los de Sinyera, la qual tanda ha de pendre dit senyor en temps que los dits vasalls de Benimixix no tinguen que fer» ${ }^{85}$

Desde luego, era todo un detalle por parte del señor requerir el servicio cuando los vasallos no tuviesen otra ocupación. Más allá, está claro que podría rebatirse fácilmente la pretensión del síndico de Benemejís de que estaban exentos de esos servicios de tiempo inmemorial o es que la memoria era muy corta. Desconozco el desarrollo del proceso y la sentencia, si es que los hubo, pero D. Francisco Joaquín Sanz no mencionó los servicios personales más que al enumerar las rentas de Señera antes de la expulsión de los moriscos.

\section{II.1.- Las rentas señoriales}

Hace ya años que Ciscar Pallarés destacaba cómo «es extraordinariamente difícil estudiar y relatar las condiciones económicas de los señoríos valencianos en el siglo XVI. Ya sea por el estado de la documentación, por las confusiones de los términos y conceptos, por lo incompleto de muchas cuentas, por lo equívoco de algunas expresiones ha exigido un enorme esfuerzo llegar a aclarar unas cuantas líneas maestras que lo definan. Al mismo tiempo, su enorme variedad y casuística local dificultan su exposición abreviada $\rangle^{86}$. Desde entonces se han publicado numerosos trabajos, pero todavía algunos intentos de síntesis apenas pasan de ser una invertebrada colección de fichas. Y no se pretende aquí abordar una «exposición abreviada», sì acaso contribuir a la variedad con una «casuística local» más.

Porque la variedad de derechos y situaciones era la tónica general, una variedad que hundía sus raíces en la época medieval y que el tiempo no hizo sino aumentar. Variedad y confusión, porque conceptos impositivos parejos se escondían tras denominaciones diferentes, porque las concordias y la dúctil costumbre habían modificado su significación hasta hacer irreconocible su origen y porque era frecuente que derechos antes distintos acabasen por fundirse en uno solo. Y todo ello influye en la dificultad

85. ARV: Real Audiencia, Procesos, 1/A/421, sin foliar, caps. 7 y 8 .

86. Eugenio CisCar Pallarés: Tierra y señorio..., p. 88. 
de identificar y clasificar algunos derechos que encontramos en Benemejís y Señera, más cuando la documentación era tan tardía y pese a la ayuda que supone el contar con la carta puebla de Señera en 1445 .

\section{CUADRO II \\ RENTAS ANTERIORES A LA EXPULSIÓN DE LOS MORISCOS (INFORME SEÑORIAL)}

\begin{tabular}{|c|c|c|c|c|c|}
\hline \multirow{3}{*}{$\begin{array}{l}\text { PARTIDA DE } \\
\text { INGRESOS }\end{array}$} & \multirow{3}{*}{$\begin{array}{l}\text { PRECIOS DE } \\
\text { REFERENCIA }\end{array}$} & \multicolumn{4}{|c|}{ INGRESOS } \\
\hline & & \multicolumn{2}{|c|}{ BENEMEJÍS } & \multicolumn{2}{|c|}{ SENERA } \\
\hline & & ESPECIE & DINERO & ESPECIE & DINERO \\
\hline Horno & & & $16-00-00$ & & $18-00-(00$ \\
\hline Tienda y panadería & & & $10-00-00$ & & $10-00-00$ \\
\hline Carnicería & & & $12-00-00$ & & $12-00-00$ \\
\hline Dos molinos & & & $350-00-00$ & \multicolumn{2}{|c|}{ No existen } \\
\hline Besante & & -- & $12-00-00$ & -- & $13-04-00$ \\
\hline Trigo & $81 . / \mathrm{ch}$. & $30 \mathrm{ch}$. & $240-00-00$ & $55 \mathrm{ch}$. & $440-00-00$ \\
\hline Cebada & $41 . / \mathrm{ch}$. & $6 \mathrm{ch}$. & $24-00-00$ & $15 \mathrm{ch}$. & $60-00-00$ \\
\hline Habas & $61 . / \mathrm{ch}$ & $4 \mathrm{ch}$. & $24-00-00$ & $12 \mathrm{ch}$. & $72-00-00$ \\
\hline Legumbres & $51 . / \mathrm{ch}$. & 2 ch. & $10-00-00$ & $2 \mathrm{ch}$. & $10-00-00$ \\
\hline Arroz blanco & $81 . / \mathrm{cg}$ & $20 \mathrm{cg}$. & $160-00-00$ & $30 \mathrm{cg}$. & $240-00-00$ \\
\hline Maíz & $51 . / \mathrm{ch}$. & $28 \mathrm{ch}$. & $140-00-00$ & $40 \mathrm{ch}$. & $200-00-00$ \\
\hline Lino limpio & $31 . / \mathrm{a}$. & $20 \mathrm{a}$. & $60-00-00$ & $30 \mathrm{a}$. & 90-00-00 \\
\hline Paja & $16 \mathrm{~d} . / \mathrm{a}$. & $800 \mathrm{a}$. & $53-06-08$ & $1.500 \mathrm{a}$. & $100-00-00$ \\
\hline Hoja & $21 . / \mathrm{cg}$. & $1.00 \mathrm{cg}$. & $200-00-00$ & $140 \mathrm{cg}$. & $280-00-00$ \\
\hline Algarrobas & $4 \mathrm{~s} . / \mathrm{a}$. & $200 \mathrm{a}$ & $40-00-00$ & $300 \mathrm{a}$. & $60-00-00$ \\
\hline Aceite & 25 s./a. & $+400 \mathrm{a}$ & $500-00-00$ & $+500 \mathrm{a}$ & $625-00-00$ \\
\hline Nueces & $4 \mathrm{r} . \mathrm{b}$ & $1 \mathrm{ch}$. & $04-12-00$ & $2 \mathrm{ch}$. & 09-00-00 \\
\hline Higos secos & $8 \mathrm{~s} . / \mathrm{a}$. & $100 \mathrm{a}$. & $40-00-00$ & $200 \mathrm{a}$. & $80-00-00$ \\
\hline Frutas frescas & -- & -- & $10-00-00$ & -- & $25-00-00$ \\
\hline Mejoría de aceitunas & 25 s./a. & $64 \mathrm{a}$. & $80-00-00$ & $92 \mathrm{a}$. & $115-00-00$ \\
\hline Gallinas & $15 \mathrm{~s} . / \mathrm{par}$ & 30 pares & $22-10-00$ & 33 pares & $25-06-00$ \\
\hline Pollos & $5 \mathrm{~s} . / \mathrm{par}$ & 30 pares & $07-10-00$ & 33 pares & $08-05-00$ \\
\hline Hilaza & & & $13-10-00$ & & $14-07-00$ \\
\hline Espaldilla & & & $01-10-00$ & & $01-13-00$ \\
\hline 2 cels. Habas & $51 . / \mathrm{ch}$. & $1 \mathrm{ch} .3 \mathrm{~b}$. & $06-05-00$ & 1 ch. 4'5 b. & $06-17-06$ \\
\hline 2 cels. Panizo & $61 / \mathrm{ch}$ & $1 \mathrm{ch} .3 \mathrm{~b}$ & $07-10-00$ & $1 \mathrm{ch} .4^{\prime} 5 \mathrm{~b}$ & $08-05-00$ \\
\hline Mejoría higos & $8 \mathrm{~s} . / \mathrm{a}$ & $30 \mathrm{a}$ & $12-00-00$ & $33 \mathrm{a}$. & $13-04-00$ \\
\hline Alfalfa & 5 s./hg. & $60 \mathrm{hg}$. & $15-00-00$ & $90 \mathrm{hg}$. & $22-10-00$ \\
\hline Granadas & $31 . /$ millar & $10-12.000$ & $36-00-00$ & $15-16.000$ & $45-00-00$ \\
\hline Cebollas & $13 \mathrm{~s} . / \mathrm{hg}$. & $30 \mathrm{hg}$. & $19-10-00$ & $50 \mathrm{hg}$. & $32-10-00$ \\
\hline Pinyol & & & $16-00-00$ & & $20-00-00$ \\
\hline Luismos & & & $30-00-00$ & & $40-00-00$ \\
\hline
\end{tabular}




\begin{tabular}{|c|c|c|c|c|c|}
\hline \multirow{3}{*}{$\begin{array}{l}\text { PARTIDA DE } \\
\text { INGRESOS }\end{array}$} & \multirow{3}{*}{$\begin{array}{l}\text { PRECIOS DE } \\
\text { REFERENCIA }\end{array}$} & \multicolumn{4}{|c|}{ INGRESOS } \\
\hline & & \multicolumn{2}{|c|}{ BENEMEJÍS } & \multicolumn{2}{|c|}{ SEÑERA } \\
\hline & & ESPECIE & DINERO & ESPECIE & DINERO \\
\hline Viña & & & & $60 \mathrm{hg}$. & $00-10-00$ \\
\hline Cavar viñas & $3 \mathrm{jn} . / \mathrm{casa}$ & & & & $37-19-00$ \\
\hline Jornales en viña & & & & & $20-00-00$ \\
\hline Jornales & & & & & $33-15-08$ \\
\hline Traslados & & & & & $+06-00-00$ \\
\hline TOTAL & & & $2.173-03-08$ & & $2.688-01-02$ \\
\hline
\end{tabular}

Fuente: AHN: Consejos, $22.243 / 4, \mathrm{ff}^{\circ} 3 \mathrm{v}^{\circ}-7 \mathrm{r}^{\circ}$ y $9 \mathrm{v}^{\circ}-12 \mathrm{r}^{\circ}$.

Abreviaturas: a. arroba: b., barchilla; cg., carga; ch., cahíz; hg., hanegada; r., real; s., sueldo. Las cifras en metálico están expresadas en libras-sueldos-dineros.

La relación detallada de los ingresos de ambos señoríos se encuentra en el memorial presentado por D. Francisco Joaquín Sanz ${ }^{87}$ Tras una primera declaración en la que enumera los conceptos impositivos en una referencia general, pasa revista, partida por partida y de forma minuciosa, a todos ellos indicando la cantidad ingresada en especie y su valor en metálico (Cuadro II). Las cifras a menudo están redondeadas y no corresponden a un año en concreto, las de las regalías son según «se acostumbrava arrendar cada un año», las de las particiones como «acostumbrava coger a su parte dicho supplicante (...) cada un año, unos años con otros, en dicho lugar en tiempo de dichos moriscos». ${ }^{88}$

Es decir, estamos ante estimaciones aproximadas cuya verosimilitud es imposible contrastar con cualquier otra documentación contemporánea, fuera de la presentada en el proceso. El señor aportó como justificantes el traslado de la carta puebla firmada por su predecesor con los entonces nuevos pobladores de Señera en 1445 y unas certificatorias de las rentas individualizadas de Benemejís y Señera. ${ }^{89}$ De éstas cabe destacar que son unas relaciones de las rentas que coinciden prácticamente en el orden con el que ofrece el pedimento del señor y totalmente en las cifras de cada una de ellas, con la excepción que veremos, pero las sumas difieren porque omiten mencionar algunas partidas significativas: en el caso de Señera, los luismos y los servicios personales; en Benemejís, además, la espaldilla de cordero, el censo en metálico sobre las tierras de

87. AHN: Consejos, 22.243/4, $\mathrm{ff}^{\circ} 2 \mathrm{r}^{\circ}-18 \mathrm{r}^{\circ}$.

88. Aunque estas expresiones hiciesen pensar en una percepción directa de las rentas por parte del señor, entre los firmantes de las certificatorias y los testigos de oficio aparecen distintos arrendatarios de cada señorío por separado o, en su caso, de los dos conjuntamente.

89. Quienes certifican la veracidad de los datos de Benemejís son Juan Antonio de Torrellas, «por aber tenido arrendado el sobredicho lugar de Benimixix por tiempo de un año antes de la expulsión de los moriscos», y Roque García, «retor de Benimixix desde el tiempo de los moros»; los de Señera el mismo Torrellas, también arrendatario de Señera, y Antonio Alberto, «arrendador que he sido del lugar de Seniera por espasio de quatro anyos antes de la espulsión de los moriscos» (AHN: Consejos, 22.243/4, $\mathrm{ff}^{\circ} 49 \mathrm{r}^{\circ}-50$ $v^{\circ}$ y $\left.52 r^{\circ}-53 v^{\circ}\right)$. 
alfalfa, las granadas, la ristra de cebollas y el derecho de almazara. Según estas certificatorias, las rentas de Señera ascenderían a 2.621 libras 6 sueldos 6 dineros y las de Benemejís a 2.043 libras 3 sueldos 8 dineros.

La contestación de los acreedores resultó moderada. ${ }^{90}$ En su impugnación de los argumentos de la parte contraria, no se detuvieron demasiado en las rentas previas a la expulsión de los moriscos y parece que no tuvieran otras vías de información que la documentación aportada por el señor, dado lo cual se dedicaron a escudriñar las diferencias entre ésta y el pedimento señorial. Aceptaban como norma reguladora de la situación de Señera en vísperas de la expulsión la carta puebla de 1445, pero destacaban que no se había presentado un documento similar para el caso de Benemejís y cuestionaban que pudiese pretenderse una identidad sustancial entre las rentas de ambos lugares. Aceptaban con reservas el monto total de los ingresos que certificaban los arrendatarios e incluso por momentos las ofrecidas por el señor, aunque a la hora de cuestionar partidas concretas aludian a que la ristra de cebollas era un «derecho imaginario», que «el de la spalda era derecho mahometano y no se podía cobrar sin pecado siendo bautizados los moros», ${ }^{91}$ que el averío y la hilaza eran para consumo de la casa del señor y no tenía sentido estimar un precio cuando no se vendían, aparte de que algunos de los barajados «son los más altos y rigurosos presios que en el districto de Xátiva se pueden arbitrar», y que los jornales estarían hipervalorados.

Con carácter general van más allá, quizás con poca convicción, y cuestionaron la percepción de luismos e incluso que las tierras estuviesen censidas, sin definirse sobre cuál sería entonces el régimen de tenencia vigente en las mismas; asimismo cuestionaban que los hornos, molinos y carnicerías fuesen propiedad del señor o que los moriscos tuviesen obligación de comprar en las tiendas de los señoríos. Sin embargo, en ningún momento discutieron unas particiones que constituían el grueso de los ingresos.

Por momentos, uno tiene la impresión de que los acreedores defendían algunos de sus argumentos con la intención de alargar el proceso hasta encontrar otros mejores, pues no se los ofrecía la documentación que tenían entre sus manos. Así, a D. Francisco Joaquín Sanz no le costó mucho rebatir los más importantes, casi sin prestarles atención, y se centró preferentemente en destacar las pérdidas atribuibles a la expulsión. Quizás por entender que era innecesario justificarlo con mayor detalle, apenas se refirió a la condición de censidas de las tierras o la propiedad de las regalías, consideraba demostrado el derecho de cebollas y las rentas de Benemejís suficientemente probadas con las certificatorias firmadas por antiguos arrendatarios del señorío.

El informe, por lo tanto, hay que tomarlo con las necesarias reservas, con las mismas que hay que tomar todos los informes de rentas elaborados con cualquier inten-

90. AHN: Consejos, 22.243/4, $\mathrm{ff}^{\circ} 54 \mathrm{r}^{\circ}-62 \mathrm{v}^{\circ}$.

91. Tenían razón en calificarlo de «derecho mahometano», pero se seguía cobrando en distintos señoríos hasta el mismo momento de la expulsión (Primitivo J. PLA AlBERoLA: «La carta puebla...», pp. 294295). 
ción. Lo cual no quiere decir que su análisis no nos permita una aproximación válida a las cuestiones que nos interesan.

En primer lugar, se impone una comparación, la de las rentas anteriores a la expulsión con la de las contempladas en la carta puebla de Señera de 1445. Y de la comparación resulta que debemos hablar de una identidad fundamental entre ambos momentos. Por supuesto hay algunas diferencias y omisiones que alimentaron las objeciones de los acreedores, aunque ya hemos dicho que algunas resultaban forzadas. En efecto, en la antigua carta puebla de Señera no se hablaba explícitamente de censo enfitéutico y de la señoría directa, pero si de establiment y de la facultad del vasallo de transmitir por herencia o venta, con la reserva por parte del señor del luismo, la fadiga y cualquier otro «jure emphiteotico» según Fueros. Tampoco se hablaba de regalías, de la obligación que tenían los vasallos de comprar en la tienda del señor, moler en su molino o cocer en su horno; pero sí del derecho de almazara, en los términos que después veremos. Quizás no hubiese molino en Señera en 1445 como tampoco lo había en 1609 , pero es más difícil creer que no existiesen tienda u horno o la obligación de que los utilizasen los vasallos, pues se podrían crear casi en cualquier momento dada la perfecta vigencia del derecho de mandamentum del señor sobre sus vasallos.

Otras diferencias más puntuales son que en 1445 se hablaba de la obligación de entregar una ristra de ajos y otra de cebollas, y no constaba esa obligación en 1609,? asimismo se diluyen los derechos de alcaidía ${ }^{93}$ y guardería; faltaba en 1445 una referencia expresa a las granadas, al censo fijo en dinero sobre las tierras sembradas de cebollas justificado en 1609 por percibirla el señor «de inmemorial»; y es difícil comparar exactamente las corveas entre ambas fechas. Sin embargo, tras siglo y medio seguían pagándose los 8 sueldos por casa, los pares de pollos y gallinas, las libras de hilaza, los almudes de panizo y habas, la arroba de aceite; más aún, eran las mismas particiones tanto en cultivos de suelo como de vuelo e, incluso, se mantenía el censo fijo en dinero de las tierras de alfalfa, cuya significación económica habría quedado muy mermada, y también la remuneración de los jornales en 10 dineros, lo cual obra a favor del señor. En cualquier caso, estamos ante una estabilidad Ilamativa de la estructura de las rentas en el largo término que casi cuesta aceptar conociendo las tensiones existentes entre ambas fechas.

Si analizamos la estructura de las rentas en vísperas de la expulsión de los moriscos, un primer grupo es el formado por derechos un tanto heterogéneos que a veces aparece bajo el epígrafe genérico de «besant y çofra», y sin entrar en la oportunidad de

92. En la relación general de las rentas que figura en los puntos 2 y 3 del memorial figura un «rastron (ristra) de cebollas por casa, pero no en el desglose detallado por partidas.

93. Igual sucede en el caso de derecho de alcaidía. En los primeros capítulos del memorial se habla de la «obligación de dar a dicho señor un celemín por cahís de qualquier specie de grano que les quedava a dichos vassallos después de hecha la susodicha partición por el derecho dicho de alcaydía», pero después no se hace constar ningún ingreso por este concepto. ¿Lo cobraba directamente el alcaide u otro oficial señorial del cual no me ha llegado noticia? ¿Quizás el mismo señor? 
semejante denominación. ${ }^{94}$ Comprendía un censo en metálico por casa de 8 sueldos a pagar en San Miguel, un par de gallinas por casa en Navidad y otro de pollos en San Juan, una espaldilla de cordero por casa el día de Pascua (conmutable por 1 sueldo); también cada casa estaba obligada a entregar al señor dos libras de hilaza (una de lino y otra de estopa), más unos pagos en especie que en unos casos más y en otros menos frecuentemente se suelen denominar de mejoría: 6 celemines por cada cahíz de aceitunas que le quedasen al vasallo tras la partición, ${ }^{95}$ y además se pagaban por casa 1 arroba de higos, 2 celemines de habas y 2 de panizo; en la carta puebla de 1445 se especificaba que la milloria de higos y habas era para compensar los frutos consumidos $y$ la de panizo «ratione ortuum».

En el capítulo de los derechos de monopolio, las denominadas regalías, nos encontramos en ambas localidades con algunos habituales hasta en los señoríos de menor entidad: carnicería, horno y tienda y panadería. Su rendimiento era poco y similar entre ambos lugares, en relación con su poca población y parejo vecindario. Son monopolios sobre el consumo a los que debemos añadir el derecho de almazara, de «pinyol y morques» o de «orujo y escoria». No consistía exactamente en la obligación de utilizar la almazara señorial, pero podemos equipararlo a ella: los vasallos, según la carta puebla de 1445, debían colectar las aceitunas y llevarlas medidas a la almazara u otro lugar seguro; el señor, a sus expensas, hacía el aceite y se quedaba con su parte y la «remolta».

Hasta aquí unas regalías que apenas aportaban el 2'5 por ciento de las rentas de estos lugares, pero el monto conjunto de las de Benemejís multiplica el de Señera (Cuadro III). La razón es simple, en Benemejís existían dos molinos, uno de trigo y otro de arroz, que suponían el 87 por ciento de las regalías del lugar. Una diferencia muy importante, y la rentabilidad de estos molinos no puede explicarse sólo porque a él acudiesen los vasallos de Benemejís, ni siquiera aunque también estuviesen obligados -que lo estarían- los de Señera cuando perteneciesen al mismo señor. ${ }^{96}$ Debemos concluir que también molerian sus granos en estos molinos los vecinos de localidades

94. Esta agrupación se inspira en la tantas veces citada carta puebla de 1445 e incluye, con toda propiedad, los tres jornales francos por casa y los demás que, por tanda, puede exigir el señor tasados a 10 dineros para cavar las viñas, pero inexplicablemente no se incluye en el mismo grupo la obligación de vendimiar y pisar la uva, que no figura expresamente en la carta puebla. Es la razón por la cual agrupo aparte todos los servicios personales. Sobre las azofras y la discusión sobre su significado véase Elia GOzÁlvez ESTEVE: «Las azofras en el marquesado de Lombay». En Esteban SARASA SÁNCHEZ y Eliseo SERRANO Martín (Eds.): Señorio y feudalismo..., vol. III, pp. 337-358.

95. Por lo tanto es un pago en aceitunas, pero a la hora de calcular su rentabilidad se utilizan los precios del aceite. La razón es que se estima el fruto que pertenece al señor expresado en cahices y, después, la de aceite correspondiente suponiendo un rendimiento de 4 arrobas de aceite por cada cahíz de aceitunas.

96. De hecho, en el arrendamiento de Benemejís de 1584 se acuerda que «per to senyor de Benimixix sia manat als vasalls de Siniera y Benimixix que molguen tots en lo molí de Benimixix» (ARV: Real Audiencia, Procesos, 1/A/421, sin foliar, cap. 19. Recordemos que el arrendador era D. Nofre Benet Sanz, señor de Benemejís por herencia y de Señera como dote de su mujer D. ${ }^{\circledR}$ Ana Sanz de Llorís. 
próximas fuera de cualquier obligación señorial, como confirmó el escueto testimonio de D. Acasi Sanz: «y en lo molí anaven a moldre de altres parts». ${ }^{97}$

CUADRO III

DISTRIBUCIÓN PORCENTUAL DE LAS RENTAS (1609)

\begin{tabular}{|l|c|c|c|c|}
\hline & \multicolumn{2}{|c|}{ BENEMEJÍS } & \multicolumn{2}{c|}{ SEÑERA } \\
\hline & A & B & A & B \\
\hline BESANTES Y AZOFRAS & $7^{\prime} 5$ & $8^{\prime} 9$ & $7^{\prime} 4$ & $7^{\prime} 6$ \\
\hline REGALÍAS & $18^{\prime} 6$ & $2^{\prime} 6$ & $2^{\prime} 1$ & $2^{\prime} 4$ \\
\hline SERVICIOS PERSONALES & NC & -- & $3^{\prime} 5$ & -- \\
\hline LUISMOS & $1^{\prime} 4$ & $1^{\prime} 7$ & $1^{\prime} 4$ & $1^{\prime} 5$ \\
\hline CENSOS EN DINERO & $1^{\prime} 6$ & $I^{\prime} 9$ & 2 & $2^{\prime} 1$ \\
\hline PARTICIONES & 71 & $84^{\prime} 9$ & $83^{\prime} 6$ & $86^{\prime} 4$ \\
\hline TOTAL & 100 & 100 & 100 & 100 \\
\hline
\end{tabular}

A: Porcentajes sobre las rentas de cada señorío.

B: Porcentajes sin tener en cuenta los servicios personales en Señera y el arrendamiento de los molinos de Benemejís.

Asimismo debemos referimos a los servicios personales. Ya hemos dicho que no figuraban más que en Señera, y ni siquiera en las certificatorias, y visto que era un derecho contestado en Benemejís. Se trataba de la obligación, por cada casa, de trabajar tres jornadas en la poda y cava de las viñas señoriales, y todos los que el señor necesitase de más a 10 dineros el jornal, además la de vendimiar, llevar la uva a casa del señor y pisarla por tanda. El valor económico de estos servicios personales lo deducía el señor a vuelapluma en el caso de los traslados y la vendimia, el de los tres jornales por casa calculándolos a 4 reales el jornal y 33 casas; el de los jornales tasados, estimando como necesarios más de 100 para el trabajo a realizar en sus vides y que el coste del jornal por el que él pagaba 10 dineros por tasa era de 7 sueldos 8 dineros, se ahorraba la cantidad indicada, con un pequeño error aritmético. Aparte, en este capítulo, hay que tener en cuenta toda una serie de trabajos de los vasallos imposibles de valorar, como la obligación de llevar los frutos a la casa del señor, la de la primera transformación del lino, el secado de los higos, el hilado de las libras de lino y estopa...

Queda un ingreso muy aleatorio como es el de los luismos, que en momento alguno se justifica y cuya importancia es irrelevante, hablar de los censos fijos en dinero sobre las tierras con apenas mayor significación ( 5 sueldos por hanegada de alfalfa, 13 por cada una de cebollas y 2 dineros en las de viñas), pero sobre todo nos queda por analizar la participación del señor en la producción agrícola. La estructura de las particiones era bastante sencilla y se prestaba a pocos equívocos: todos los cultivos de suelo, excepto los que pagaban un censo fijo en dinero, partían al tercio en el regadío,

97. AHN: Consejos, $22.243 / 4, f^{\prime \prime} 63 \mathrm{v}^{0}$. 
al cuarto en el secano y al octavo «los que se cogían en las montanyas y tierra más áspera», a lo que había que añadir el tercio de la paja del trigo y la cebada; en todos los de vuelo el señor percibía la mitad. Los vasallos tenían la obligación adicional de llevar la parte que le tocaba a la casa del señor. Había algunas excepciones, además de la mencionada: la hoja se partía en el árbol y de los higos el señor sólo percibía la tercera parte, pero entregados ya secos. Y unas dudas: ¿se partían las cosechas tras haber pagado el diezmo? ¿se partían los granos deducida la simiente? En cualquier caso, las particiones constituían la parte fundamental de los ingresos señoriales, con mucha diferencia, hasta el punto de que suponían hasta más de las cuatro quintas partes de las mismas (Cuadro III).

Entrando en un análisis más pormenorizado, esta estructura de las rentas constituye, además, un magnífico indicador de la diversidad de los cultivos y su importancia relativa. ${ }^{98}$ Por los ingresos que reportaban a las arcas señoriales, a la cabeza se encontraban los olivos -supongo que el cultivo predominante en el secano-, cuyo fruto se dedicaba esencialmente a su transformación en aceite, pero sin olvidar que más de un 10 por ciento de la producción se dedicaría al consumo directo tras su aliño, de ahí el pago de la mejoría. Le seguía en importancia toda una serie de cultivos preferentemente de regadío: 99 en primer lugar encontramos el trigo; después, la hoja, el arroz, el maíz... En este ámbito, de forma sucinta, me permito llamar la atención sobre la importancia de los frutales: el epígrafe de frutas frescas comprendía «pomas, durasnos, peras, ceresas y otros frutos»; las nueces y, sobre todo, granadas e higos, que partían ya secos y pagaban mejoría por los consumidos frescos. Asimismo sobre los productos forrajeros, que permitirían una ganadería estabulada de la que nada nos dice la documentación. Por último, destacar el maíz; inequívocamente el maíz, pues se habla de «daça de Indias». Un cultivo del que aún sabemos muy poco: que se introdujo en la segunda mitad del siglo XVI, después de que escribiese Viciana y antes que lo hiciese Escolano; ${ }^{100}$ en Alcocer, una localidad del interior montañoso alicantino, en 1593 ya era el tercer cereal en importancia y representaba un tercio de la cosecha del trigo... ${ }^{101}$ En Benemejís y Señera, era el segundo cereal y su producción sólo un 20 por ciento inferior a la de trigo.

Hasta ahora hemos hablado de las partidas de las que nos informa la documentación, pero faltan algunos ingresos que son habituales en muchos otros señorios. $\mathrm{El}$

98. Una panorámica de la evolución de los cultivos en la comarca en Tomàs PERIS ALBENTOSA: História de la Ribera..., vol. II, pp. 79 y ss.

99. D. Acasi Sanz, uno de los testigos de oficio, dirá que «en lo secà no-s collien grans sinó molt pochs» (AHN: Consejos, 22.243/4, f' 63 ro $^{\circ}$.

100. Antonio LOPEZ GÓMEZ: «La introducción del maíz en Valencia y la sustitución de otros coreales». Estudios Geográficos (Madrid), n 135 (1974), pp. 117-156.

101. Primitivo J. Pla Alberola: «Despoblación y repoblación. La crisis del XVII en el Cuartel de La Marina y Las Montañas». En Jordi NADAL OLLer (Coord.): Evolución demográfica bajo los Austrias (Actas del II Congreso de la Asociación de Demografia Histórica. Alicante, abril de 1990. Volumen III). Instituto de Cultura Juan Gil Albert-Seminari d'Estudis sobre la Població del País Valencià, Alicante, 1991, p. 208. 
caso más llamativo es que en ningún momento se habla de que el señor percibiese el tercio diezmo, menos el diezmo entero, tampoco ningún ingreso por el ejercicio de la jurisdicción ni otros asimismo habituales como los de pastos. En este último caso cabría atribuirlo a que las autoridades de Játiva siempre fueron celosas defensoras de sus privilegios sobre los pastos de un extenso territorio mucho más allá de su término municipal; el que no percibiese el tercio diezmo porque no existiría la correspondiente concesión real y estaba muy cerca el baile de Játiva como para permitir a un pequeño señor su adquisición de forma subrepticia; pero sabemos que, aunque fuese discutido su nivel de competencias y la documentación sea paupérrima, el señor sí que tomó algunas decisiones en el terreno de lo judicial que le reportarían algunos ingresos, por pocos e irregulares que fueran. Todo ello sin olvidar que el señor tenía unas tierras que gestionaba directamente -como más citadas las viñas, pero también, en uno u otro momento, olivares, higuerales, cañaverales...- ${ }^{102} \mathrm{y}$ de cuyo producto no se nos dice nada.

Así, la estructura de las rentas de Benemejís y Señera difiere notablemente de buena parte de las publicadas hasta ahora. Poco o nada tiene que ver con la de esos señoríos que tenían las tierras francas de cualquier derecho o, a lo sumo, estaban gravadas con censos en dinero, a menudo desvalorizados con el transcurso del tiempo. Señoríos donde los ingresos más importantes provenían del arrendamiento de las regalías, que llegaban a suponer cerca de la mitad del total, y como único ingreso en especie significativo estaba el tercio diezmo, más aún si el señor percibía el diezmo por entero. Los ejemplos que comentamos aquí se encuentran en el extremo opuesto, y para encontrar otros más similares debemos acudir a señoríos como Benasáu, ${ }^{103}$ donde los ingresos del señor eran poco más que las particiones señoriales, particiones en la órbita de las que hemos visto en Benemejís y Señera: la mitad de los frutos del arbolado, entre la mitad y la cuarta parte de la cosecha de cereales, legumbres y hortalizas, con contadas excepciones.

Esta estructura de las rentas repercute de forma inmediata en la rentabilidad de unos y otros señoríos, la cual podemos medir por la aportación media de cada familia de vasallos al señor. Acudiendo a este criterio, discutible, y asumiendo las dificultades de las fuentes, el señor percibiría en Benemejís 1.449 sueldos por casa y 1.694 en

102. Veremos que los acreedores aludirán a su existencia, pero de forma tan genérica que podría pensarse en una referencia insubsistente. Algunos datos concretos, pocos, nos hacen ver que no era así. En el arrendamiento de Benimejís de 1584 , los arrendatarios se comprometieron a realizar toda una serie de labores en tierras que suponemos del señor, tanto morerales como viñas, y éste se reservó el cañar Ilamado de Benemejís (ARV: Real Audiencia, Procesos, 1/A/421, sin foliar, cap. 14). Años después, en 1604, cuando se discutian los servicios personales de los moriscos, se denunciaba que el señor conminaba a sus vasallos a que «li prometesen de fer jornals en ses terres y heretats», concretando que a un morisco «lo posa pres y no-l volgué traure de la presó fins tant aquell li prometés de llaurar de tres relles un figueral del dit senyor que té trenta fanecades de terra y més» (ARV: Real Audiencia, Procesos, $\left.1 / \mathrm{S} / 1.660, \mathrm{f}^{\mathrm{f}} 5 \mathrm{r}^{\mathrm{o}} \mathrm{y} \mathrm{\textrm {v } ^ { \circ }}\right)$.

103. Primitivo J. Pla Alberola: «Capitols de nova població del lloch de Benazau, 1611 » Revista del Instituto de Estudios Alicantinos (Alicante), nº 39 (1983), pp. 125-155. 
Señera. En lo que conozco, son los señoríos más rentables del reino de Valencia en los primeros años del siglo XVII, con diferencia.

Pero quiero volver sobre la estructura de las rentas, haciendo ver, contra lo que podríamos pensar por lo dicho hasta ahora, que las documentadas en Benemejís y Señera no son tan insólitas, pues particiones similares las encontramos en un número importante de señoríos que tenían algunas características en común. ${ }^{104}$ Una es que eran señoríos de corto vecindario, aunque con fuertes diferencias: desde unas pocas casas hasta casi el centenar. Pero el elemento definitorio de estos señoríos es que estaban o habían estado explotados en un régimen de tenencia de la tierra de tradición islámica: la exariquería ${ }^{105}$ Mientras el régimen de tenencia de la tierra predominante en el lugar fuese esa aparcería, se hablaba de ellos como alquerías y perdían tal denominación cuando las tierras y casas se acensuaban de forma generalizada; era, pues, un término que hacía referencia a una realidad concreta y con esa significación se mantendría sólo en las comarcas con una importante presencia de mudéjares o moriscos, mientras que en las comarcas de población cristiana el término alquería pasó a definir otra realidad o quedó fijado en la toponimia. ${ }^{106} \mathrm{E}$ establecimiento a censo, normalmente mediante la respectiva carta puebla, suponía que los cultivadores directos -que ni siquiera siempre eran vasallos de quien se titulaba señor de la alquería- adquirían derechos de propiedad, transmisibles, sobre unas casas y tierras que desde entonces en buena medida podían considerar suyas. Sin embargo, era habitual que tras el establecimiento se mantuviesen las mismas rentas agrarias vigentes cuando regía la aparcería, aunque no falten ejemplos donde se optó por un pago fijo en especie. ${ }^{107}$

Son contados los elementos de juicio que tengo sobre estas cuestiones referidos a Benemejís y Señera, y ello hace que debamos ser prudentes en su interpretación, pero encajan en el esquema sucintamente expuesto. En la carta puebla de 1445 todavía se hablaba del «loci sive alqueree vulgariter nuncupate Çeniera, in termino civitatis constructi», ${ }^{108}$ nunca se utilizará esa denominación con posterioridad. La última vez que Benemejís viene citado como alquería es en 1486, cuando el magnífico Francisco Luis Bou, caballero, se titulaba «domino loci seu alquaree bocate Benimixis, situati seu situate intra generales terminos civitatis Xative», y en el mismo documento se men-

104. Primitivo J. Pla Alberola: «Apuntes para el estudio de las rentas señoriales en el siglo XVI. Los pequeños señorios del Quartel de las Montañas». Jerónimo Zurita, su época y su escuela. Institución Fernando el Católico, Zaragoza, 1986, pp. 259-265.

105. Primitivo J. PLA Alberola: «Exáricos valencianos». España y el Norte de Africa. Bases históricas de una relación fundamental. Publicaciones de la Universidad de Granada, Granada, 1987, vol. 1, pp. 391-398.

106. Primitivo J. Pla Alberola: «Condiciones de tenencia de la tierra y jurisdicción en el siglo XVI valenciano: hacia una tipificación de las alquerías moriscas». En La propiedad ristica en España y su influencia en la organización del espacio. Secretariado de Publicaciones de la Universidad de Alicante, Alicante, Alicante, 1981, pp. 53-63.

107. Primitivo J. Pla Alberola: «'Capitols del stabliment de Turballos', 1515». Revista de Historia Moderna (Alicante), nn 8-9 (1990), pp. 289-303.

108. Primitivo J. PLA AlBerola: «La carta puebla...», pp. 285 y ss. 
ciona repetidas veces al «loquo seu alquarea» de Benemejís. ${ }^{109}$ No sé cuando pudieron establecerse los inmuebles del lugar ni lo sabía su señor a la hora de redactar el memorial que presentó al Dr. Salvador Fontanet en 1612. Lo único que puedo decir es que en el arrendamiento de 1584 se habla de luismos, ${ }^{110} \mathrm{o}$ sea que entonces las tierras del lugar estaban ya establecidas a censo.

Podría objetarse que esa identificación entre alquería y régimen de tenencia de la tierra, con el añadido de tan exigente nivel de rentas, sería ajena a esta comarca y, en lo que conozco, no se suscita en la bibliografía hasta el momento. Tenemos referencias a núcleos de población citados como alquerías, sabemos de su importancia numérica al poco de la conquista de estas tierras por las huestes cristianas y su paulatina disminución en el transcurso del tiempo. ${ }^{111}$ Todavía el vecindario de 1510 nos menciona un buen número de ellas bajo el epígrafe «Les alqueries de la orta de la dita ciutat»: entre otras, «la alqueria de n'Anrich Tallada», «la alqueria d'en Moltó», «la alqueria d'en Miquel Ganceran Sanç», «la alqueria del Canonge Rotlà»... ${ }^{12}$

Sin embargo, en mi corto escudriño por los protocolos de notarios que trabajaron en Játiva a fines del siglo XV y se conservan en el Archivo del Colegio del Patriarca (un par de volúmenes en búsqueda de la última voluntad del entonces señor de Señera), casi podríamos decir que he tropezado con el arrendamiento en 1484 de la última de las alquerías citadas: «la alqueria appel·lada Alcúdia Blanca», en el término de Játiva, perteneciente al canónigo Ausias Rotglá. En él se menciona tierra censida, aunque parece tratarse sólo de una viña, y en general se habla de los mudéjares que en ella residen como de «statgers e pobladors», las rentas citadas están en la órbita de las que venimos siguiendo: la mitad de la producción del arbolado (excepto los higos que partían al tercio), la tercera parte en las tierras de regadío y la cuarta en las de secano, con otras de presumible menor significación como una arroba de aceite por casa, 5 sueldos por hanegada de alfalfa, el besante de 23 sueldos y 6 dineros pagaderos por quienes tuviesen «heretat complida»y sólo 10 sueldos quienes poseyesen casa sin tierras... ${ }^{113}$

Al señor le interesaba sobremanera tener sus tierras en esa aparcería de tradición

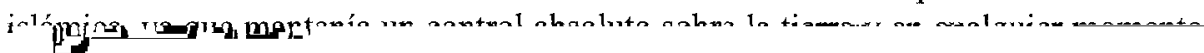


cuando quisiese abandonar la tierra, sin más obligación que la de saldar cuentas con el señor. Pero tenía un coste importante: la inestabilidad de la mano de obra, sobre todo en los momentos en que faltaba población. De hecho, en el arrendamiento citado se contempla que si «se dessavasallarà o mudarà algun vassall o tots» durante los siete años del contrato, el arrendatario se quedase con las cantidades que satisficiesen al rendir cuentas a la señoría «per a obs d'enprestar aquella o aquelles a altre o altres vassalls qui lladonchs volran venir e star e fer-se vassalls de dit loch o alqueriay.

En estas condiciones, y pese a todas las disposiciones existentes limitando la movilidad de los mudéjares de señorí - en las cuales se insistía una y otra vez que no podían abandonar su lugar de residencia sin pasar cuentas con el señor--, existían continuados conflictos entre los propios señores queriendo atraer una mano de obra imprescindible para poner en valor su patrimonio territorial. Tenemos constancia de esos conflictos por doquier y noticias de que también se dieron en los señoríos que estudiamos: en 1430, el caballero Bernat Ramón Sanz, señor de Benemejís, denunció la huida de sus vasallos a Alcira, solicitando su regreso al lugar para pasar cuentas y asegurando que después quedarían libres para fijar su residencia donde quisieran; pero quizás no se fiasen mucho cuando el mismo señor apresó a quienes volvieron desde Corbera precisamente para pasar cuentas. ${ }^{115}$

En esta situación ¿qué podían hacer los señores para atraer vasallos a sus tierras y lograr que en ellas residiesen de forma estable? La mejor vía para conseguirlo era ofrecer distintos privilegios, como los concedidos por el vecino señor de Sumacárcer, ${ }^{116} \mathrm{y}$ sin duda el más preciado entre ellos sería el de conceder a los mudéjares derechos de propiedad sobre las tierras que cultivaban. Tras la firma de la carta puebla en un lugar hasta entonces alquería también podían existir otras consideraciones, especialmente la necesidad de liquidez del señor. Un señor fuertemente endeudado podía estar interesado en ceder el dominio útil -casi podríamos decir venderlo- a cambio de un generoso servicio monetario en forma de entrada de los establecimientos a censo, cuyo pago cabía pactar en plazos. ${ }^{117}$

\section{II.2.- El problema de las deudas}

Si hasta aquí hemos estado hablando de rentas, obligado es referirse ahora a la otra cara de la moneda, las deudas a las que debía responder el señor cuando fueron expulsados sus vasallos moriscos.

Es conocido el alto grado de endeudamiento de la sociedad valenciana a principios del siglo XVII, cuando desde unos lustros atrás parecía atravesar por dificultades el crecimiento registrado en buena parte del Quinientos; y los señores en modo alguno

(Alicante), ñ 2 (1983), pp. 119-138.

15. Carlos López. Rodriguez: Nobleza y poder político..., p. 165.

116. Juan P. GAllanA ChACón y Vicente PONS Alós: «La carta puebla de Fondos: la Ribera a finales del siglo XV». Actes de la V Assemblea d'Història de la Ribera. Ajuntament, Almusafes, 1993, pp. 66 y ss.

117. Primitivo J. Pla Alberol A: «'Capitols del stabliment...», pp. 293-295. 
constituían una excepción. ${ }^{118}$ Existía una auténtica maraña de intereses cruzados difíciles de desbrozar, los cuales, si ya habían demostrado su potencial conflictividad antes de la expulsión, hicieron que, con ella, el problema adquiriese tales dimensiones que lastró decisivamente el proceso repoblador y ocupó a los tribunales durante mucho tiempo, prueba de ello es que el 61 por ciento de las sentencias pronunciadas por la Real Audiencia entre 1609 y 1626 tocantes a cuestiones relacionadas con la expulsión de los moriscos se referían a los censales. ${ }^{119}$ Quienes se han interesado por este proceso son perfectamente conscientes de ello, pero, en palabras de Emilia Salvador, «el tema de los censales relacionado con la expulsión no ha sido abordado todavía en profundidad», preguntándose si en dicha preterición ha pesado el descomunal y heterogéneo volumen de documentación existente, pese a que las pérdidas han sido muchas. ${ }^{120}$

Ahora bien, los estudios realizados, con todos sus problemas, evidencian que es incorrecto hablar en términos generales, sin atender a la diversidad de situaciones que se daban en la realidad. ${ }^{21}$ Pues existían diferencias de escala, porque nada tienen que ver, por ejemplo, las cantidades que se barajaban en el caso del duque de Gandía con las que veremos aquí. Diferencias también en términos relativos, pues si había señores que no necesitaron de la expulsión para estar prácticamente en bancarrota, otros podían hacer gala de una hacienda mucho más saneada.

El señor de Benemejís y Señera, adelantando conclusiones, parece encontrarse en el segundo grupo hasta 1609. En el primer memorial presentado por D. Francisco Sanz es donde encontramos la enumeración más detallada de las deudas que debía satisfacer el señor todos los años, ${ }^{122}$ en unas anotaciones que tienen todo el aspecto de haber sido tomadas de un libro pagador particular, pues están ordenadas por meses de vencimiento del pago, como suele ser habitual en estos libros. Las anotaciones son correctas en la medida que las hemos podido comparar con los libros de la Colegiata de Játiva y algunas escrituras notariales, ${ }^{123}$ pero escuetas: el nombre del acreedor, su profesión y lugar de residencia, el mes en el que cae la pensión y la cuantía de la misma, con algunas omisiones en la indicación de profesión y residencia. Echamos en falta otros datos que hubiesen sido interesantes: principal del censal, fecha de su constitución y

118. Se ha propuesto, asumiendo muchos riesgos y con un carácter puramente orientativo, que las deudas consumirian algo más de la tercera parte de las rentas señoriales antes de la expulsión. Véase James CASEY: «La situación económica de la nobleza valenciana en vísperas de la expulsión de los moriscos». Homenaje al Dr. D. Juan Reglà Campistol. Universidad de Valencia, Valencia, 1975, vol. I, pp. 521 522. Este trabajo se ha publicado después en James CASEY: La terra i els homes. El País Valencià a l'època dels Áustria. Ed. Afers, Catarroja-Barcelona, 2005, pp. 31-44.

119. Pascual Marzal Rodriguez: «Conflictos jurídicos a raíz de la expulsión de los moriscos valencianos». Estudis. En torno al XVII Hispánico (Valencia), n 20 (1994), pp. 186-187.

120. Emilia SALVAdor EsTeban: «La cuestión de los censales...», pp. 127-128.

121. Una primera aproximación podemos encontrarla, por ejemplo, en el citado trabajo de James CASEY y en Eugenio CISCAR PALLARÉs: Tierra y señorío..., pp. 114 y ss.

122. AHN. Consejos, 22.243/4, $\mathrm{ff}^{\mathrm{o}} 14 \mathrm{v}^{\circ}-17 \mathrm{v}^{\circ}$.

123. Hay diferencias puntuales, normalmente de escasa entidad, a las que no se puede suponer intencionalidad sino atribuir a errores mecánicos. 
posteriores transmisiones, razón o razones que están en su origen... La documentación complementaria que ha llegado a mis manos sólo parcialmente permite subsanar algunas de esas deficiencias.

$\mathrm{Ni}$ en los memoriales del señor ni en las réplicas de los acreedores se aclaran algunas cuestiones, quizás porque las den por supuestas. Entendemos que todo son deudas censales, salvo el último pago anotado que corresponde a una pensión por alimentos que debe satisfacer el señor a su hermano, D. Joan Sans de Señera; y los casos que hemos podido documentar por otras vías así lo confirman, aunque no podamos descartar la existencia de algún violario o debitorio. Que son censales cuya constitución es anterior a la expulsión de los moriscos y que están asegurados sobre las rentas señoriales; y la documentación también lo confirma y hace ver que D. Francisco responde otros censales que gravan bienes inmuebles ajenos a los señoríos. Pero lo que no podemos saber es si estaban cargados sobre ambos señoríos o, lo que es más probable, sobre cada uno de ellos, pues en ningún momento se contempla diferencia en el memorial. Nos consta que algunos censales estaban cargados originalmente sobre uno u otro lugar, aunque no podemos dilucidarlo en un número significativo de casos. ${ }^{124} \mathrm{Y}$ la indefinición resultante constituye una laguna que pudo tener sus consecuencias con posterioridad, pues, tratándose de señoríos hasta poco tiempo atrás independientes, los acreedores podían haber requerido que se hiciese un balance por separado de las rentas y deudas de cada uno de ellos.

En total, según el memorial presentado por D. Francisco Joaquín Sanz, son 17 los perceptores de las pensiones de 38 censales, cuyos intereses suman 1.026 libras 14 sueldos 1 dinero, aunque el señor ofrece la suma final de 1.226 libras 14 sueldos 7 dineros (Cuadro IV). La diferencia se explica por un error de suma de una ínfima cantidad ( 6 dineros) y porque el señor incluye también las 200 libras de alimentos; conviene recordar tal cifra por utilizarla como referencia en la posterior discusión con los acreedores.

\section{CUADRO IV \\ DEUDAS DE D. FRANCISCO JOAQUÍN SANZ, SEÑOR DE LOS LUGARES DE BENEMEJÍS Y SEÑERA (INFORME SEÑORIAL)}

\begin{tabular}{|c|c|c|c|c|}
\hline $\begin{array}{c}\text { MES DE } \\
\text { PAGO }\end{array}$ & ACREEDOR & PROFESIÓN & RESID. & CUANTÍA \\
\hline 01 & $\begin{array}{c}\text { Dr. Albinyana y Hier }{ }^{\pi} \text { Real, «muger } \\
\text { y heredera» }\end{array}$ & Dr. en Derecho & [Játiva] & $33-06-08$ \\
\hline 01 & ${\text { Marco Ant }{ }^{\circ} \text { Anguerot }}^{\text {Mariva }}$ & Nc & Játiva-00-00 \\
\hline
\end{tabular}

124. En el arrendamiento de Benemejís en 1584, el arrendatario se comprometió al pago de los intereses de 27 censales por un total de 465 libras 3 sueldos 5 dineros, y muchos de esos censales se seguían pagando en 1609 (ARV. Real Audiencia, Procesos, 1/A/421, sin foliar, cap. 12), pero la consignación del pago de los censales en dicho arrendamiento no asegura que todos ellos estuviesen cargados especialmente sobre dicho señorio, más cuando D. Onofre Benet Sanz ya se titulaba también señor de Señera tras su matrimonio con D." Ana Sanz. 


\begin{tabular}{|c|c|c|c|c|}
\hline $\begin{array}{c}\text { MES DE } \\
\text { PAGO }\end{array}$ & ACREEDOR & PROFESIÓN & RESID. & CUANTÍA \\
\hline 01 & Cabildo & Eclesiástica & Játiva & $8-03-00$ \\
\hline 01 & Gaspar Texedor & $\mathrm{Nc}$ & Játiva & $15-00-00$ \\
\hline $\mathrm{Nc}$ & ¿? SanJuan & Beneficiado & $\mathrm{Nc}$ & $15-00-00$ \\
\hline 02 & Hierónyma Real & [Dr. en Derecho] & [Játiva] & $40-00-00$ \\
\hline $02 / 08$ & Hierónyma Real & [Dr. en Derecho] & [Játiva] & $166-13-04$ \\
\hline 02 & D. Balt. Sans de la Llosa & Dr. en Derecho & [Valencia] & $112-10-00$ \\
\hline 03 & Hierónyma Real & [Dr. en Derecho] & [Játiva] & $33-06-08$ \\
\hline 03 & Cabildo & Eclesiástica & Játiva & $16-13-04$ \\
\hline $03-09$ & Monasterio de Montsant & Eclesiástica & Játiva & $31-04-00$ \\
\hline 03 & Thomas Real & Ciudadano & Játiva & 9-03-04 \\
\hline 04 & Thomas Real & [Ciudadano] & [Játiva] & 8-13-04 \\
\hline $\mathrm{Ne}$ & Hierony Magil & $\mathrm{Ne}$ & Canales & $14-07-06$ \\
\hline 05 & Hierónyma Real & [Dr. en Derecho] & [Játiva] & 8-06-00 \\
\hline $05 / 11$ & D. Balthasar Ladrón & Cab. Montesa & $\mathrm{Nc}$ & $20-00-00$ \\
\hline $05 / 11$ & Dr. Jayme Margarid & Dr. & Valencia & $20-03-10$ \\
\hline 05 & Cabildo & Eclesiástica & [Játiva] & $2-07-11$ \\
\hline 06 & $D^{a}$ Angela Scrivà & [Caballero] & Valencia & 73-06-08 \\
\hline $06-12$ & D. Francisco Sans de Alboy & [Caballero] & $\mathrm{Nc}$ & $100-19-08$ \\
\hline $06-12$ & $\mathrm{D}^{\mathrm{a}}$ Francisca Torrellas & [Caballero] & $\mathrm{Ne}$ & $34-00-04$ \\
\hline 07 & Cabildo & Eclesiástica & [Játiva] & $15-16-08$ \\
\hline 07 & Hierónyma Real & [Dr. en Derecho] & [Játiva] & $26-13-04$ \\
\hline 08 & Cabildo & Eclesiástica & [Játiva] & $07-05-00$ \\
\hline 08 & Cabildo & Eclesiástica & [Játiva] & $15-00-00$ \\
\hline 08 & Laudomia Adarroy & Sra. de Cerdá & $\mathrm{Nc}$ & $11-05-00$ \\
\hline 09 & Cabildo & Eclesiástica & [Játiva] & $13-16-08$ \\
\hline 10 & Cabildo & Eclesiástica & [Játiva] & $7-10-00$ \\
\hline 10 & Joan Anthonio de Torrellas & Caballero & Játiva & $66-13-04$ \\
\hline 11 & Thomàs Real & Ciudadano & Játiva & $8-06-08$ \\
\hline 11 & Hierónyma Real & [Dr. en Derecho] & [Játiva] & $16-13-04$ \\
\hline 11 & Cabildo & Eclesiástica & [Játiva] & $2-06-08$ \\
\hline 11 & Cabildo & Eclesiástica & [Játiva] & $13-06-08$ \\
\hline 12 & Cabildo & Eclesiástica & [Játiva] & $6-13-04$ \\
\hline 12 & Cabildo & Eclesiástica & [Játiva] & $3-06-08$ \\
\hline 12 & Cabildo & Eclesiástica & [Játiva] & $20-00-00$ \\
\hline 12 & Cabildo & Eclesiástica & [Játiva] & $7-10-00$ \\
\hline [12] & Convento Predicadores & Eclesiástica & Játiva & $15-04-06$ \\
\hline $\mathrm{Nc} 1 / 2$ & D. Joan Sans de Señera & Caballero & [Játiva] & $200-00-00$ \\
\hline
\end{tabular}

Fuente: A.H.N.: Consejos, $22.243 / 4, \mathrm{ff}^{\circ} 14 \mathrm{v}^{\circ}-17 \mathrm{v}^{\circ}$. 
Los acreedores, en su contestación al señor, no prestan especial atención al tema de las deudas que éste debe afrontar, puesto que de los treinta y un capítulos del memorial sólo uno, aunque extenso, lo dedican específicamente a él. ${ }^{125}$ En este capítulo encontramos unas digresiones generales sobre lo privilegiados que son los créditos censales, «assí por disposiciones comunes de derecho como también municipales de fueros, pragmáticas y privilegios en su favor conçedidos y jurados», y que, por lo tanto, no cabe reducción de los intereses si no es amortizando los capitales; destacan, en los términos habituales de otros memoriales elaborados por entonces, que «la mejor sustancia y renta de todo este reyno consiste en censos, de que biven y se sustentan sus estados más principales que son el eclesiástico y militar y la mayor parte de la nobleza», y sus dramáticas consecuencias: «cessación de los suffragios de las almas de purgatorio» $\mathrm{y}$ «de infinidad de obras pías instituydas por los fieles deffunctos», que sólo beneficiarian a plebeyos y señores de vasallos. En un terreno más concreto, simplemente manifiestan su reserva sobre que fuesen censales todos los pagos enumerados por el señor y que la pensión por alimentos que pagaba a su hermano debiese tenerse en cuenta entre los créditos contra el señor en igualdad de condiciones. En todo caso, su argumento principal es que los ingresos posteriores a la expulsión son más que suficientes para hacer frente al pago de los intereses de la deuda, cuestión sobre la que volveremos más adelante.

El señor parece encantado con la duda manifestada sobre sus deudas, «porque ninguno más que él se olgará que no la tengan, pues además de redundar en su provecho sería muy de su gusto». Destaca el carácter privilegiado que asimismo tienen los pagos por alimentos y entra en las disquisiciones de carácter más general: incluso el señor directo puede ver reducido el censo que percibe del enfiteuta en un caso tan inopinado como era el de la expulsión de los moriscos, mantener intactos los intereses «sería enriqueser los censalistas para que solos gossasen de todos los benefiçios de la expulçión», de todo lo cual deduce que «la reducçión de dichos çensales no sólo procede de buena razón destado pero de mucha justicia y equidad». Además, aprovecha la ocasión para solventar un descuido anterior: también debe pagar 35 libras a sus hermanas Nicolasa y Petronila, monjas profesas en el monasterio de Nuestra Señora de la Consolación de Játiva. ${ }^{126}$

Las diferencias no son muy significativas, dadas las que veremos en otros apartados, pero la cifra que se convierte en definitiva es la que resulta de las investigaciones de la burocracia real. Debió ser una tarea de investigación importante, de la cual no conozco especiales referencias. Mateo Ferro, bajo el epígrafe «Censales y cargos proprios del señor de dichos lugares cargados por su qüenta y de sus predecessores sacados de los manifiestos de la visita», cita los «manifiestos hecho en Valençia», «los manifiestos de Xátiva» y «el manifiesto de Castellón», concretando volúmenes y folios, en los cuales constan «como verisímiles y indubitables» deudas por cuantía total de 17.586 libras 5 dineros que generan un interés anual de 1.322 libras 7 sueldos

125. AHN. Consejos, 22.243/4, ffo $54 \mathrm{r}^{\circ}-56 \mathrm{v}^{\circ}$. Las referencias concretas al tema de las deudas en $\mathrm{ff}^{\circ} 54 \mathrm{r}^{\prime \prime}-55 \mathrm{r}^{\circ}$. 126. AHN. Consejos, $22.243 / 4, f^{\circ} 67 r^{\circ}-69 v^{\circ}$ y $83 v^{\circ}-84 r^{\circ}$ 
3 dineros, ${ }^{127} \sin$ que entre ellas incluya las deudas por alimentos y sin que tampoco diferencie las que gravaban a uno u otro señorío. ${ }^{128}$ Una cifra superior a la contemplada en el informe señorial, sin que podamos dilucidar las razones de semejante incremento.

En cualquier caso, son diferencias poco significativas que nos llevan a la conclusión de que estamos ante un nivel de endeudamiento relativamente moderado en vísperas de la expulsión de los moriscos, muy lejano del que debían afrontar otros muchos señores valencianos, pues apenas consumiría la cuarta parte de sus ingresos ordinarios pensiones por alimentos aparte-. Ello explica que no tengamos noticias sobre dificultades en el pago de los intereses antes de la expulsión de los moriscos, con una excepción: en 1607, D. Baltasar Sanz de la Llosa inicia un proceso en la Gobernación y luego lo introduce en la Real Audiencia por el impago de 56 libras; resulta confuso quién es el demandado, si las universitats o el señor, y sorprendente la reclamación de una cantidad que supone sólo la mitad del interés anual. ${ }^{129}$

Ahora bien, ir más lejos en el análisis de este endeudamiento es difícil con la documentación llegada a mis manos, sin que podamos saber las causas que lo originaron o si era reciente o antiguo, más allá de apuntar que el señor niega que se debiese a la adquisición del señorío y los pocos documentos que aportan alguna luz hablan de mandas testamentarias de sus predecesores, entre otras razones similares.

Es una deuda bastante repartida entre 17 personas e instituciones, entre las que predominan los acreedores de la oligarquía local y personas muy vinculadas a la misma, pues el conjunto de las instituciones eclesiásticas apenas perciben algo más del 20 por ciento de los intereses pese a acumular cerca del 49 por ciento de los censales. A título individual, los mayores acreedores son el Dr. Albiñana y su «muger y heredera» -entendemos que su viuda- Jerónima Real con tercio de las deudas $\mathrm{y}$, a mucha distancia, el Cabildo setabense con un 13 por ciento; sólo hay otros dos perceptores, cada uno con un censal, que superen las 100 libras de interés anual: D. Baltasar Sanz de la Llosa y D. Francisco Sanz de Alboy.

Nos interesa identificar quiénes son estos máximos acreedores, y no pueden ser otros que micer Juan Bautista Albiñana y Jerónima Real. D. Juan Bautista Albiñana, hijo de un cives, asesor del lloctinent de portantveus de general governador de Játiva, debió labrar una fortuna considerable y lograr una posición social que pretendía ver coronada alcanzando la condición de señor, para él o sus descendientes. Así, dotó generosamente a su hija D. ${ }^{a}$ Beatriz al contraer matrimonio con D. Miguel de Fenollet Ripoll de Castellvert, antes Rosell, baile de Játiva; y en las capitulaciones matrimoniales de 28 de abril de 1605 se vinculó el pago de la dote a las inversiones necesarias para construir un nuevo lugar del que los cónyuges pudiesen titularse señores: el Lugar

127. Estas cifras suponen un interés medio del 7'5 por ciento. En la pragmática de 2 de abril de 1614 (Pascual BORONAT y BARRACHINA: Los moriscos..., vol. II, p. 613) se habla de que en Játiva era corriente un interés intermedio entre los pactados en el reino, de 18 y 20 dineros por libra ( $7^{\prime} 5$ y $8^{\prime} 3$ por ciento), pero el máximo interés que he podido documentar es del 7 '5 por ciento, otros censales están cargados al 6' 7 y unos pocos al 5 por ciento.

128. AHN. Consejos, 22.243/4, cuadernillo entre los $\mathrm{ff}^{\circ} 39$ y 41, pp.3-4.

129. ARV: Real Audiencia, Procesos, 2/B/577. 
Nuevo de Fenollet. D. ${ }^{a}$ Beatriz Albiñana y Real, tras serle restituida la dote el 30 de junio de 1610 , se titulará señora del lugar. ${ }^{130}$

Puede pensarse en el parentesco que tendría con los citados ese otro acreedor, más modesto, que es Tomás Real, ciudadano de Játiva. Pero hay otras relaciones familiares que no aparecen explícitas en la relación de acreedores. En la concordia firmada en 1618 entre éstos y el señor, figura D. Gaspar Ferre de Calatayud como procurador de su mujer, D. ${ }^{a}$ Isabel Albiñana, y de D. ${ }^{a}$ Potenciana Albiñana, esposa de D. Juan Sanz de Señera, ${ }^{131}$ en 1619, D. ${ }^{a}$ Beatriz Albiñana, viuda de D. Miguel Fenollet, D. ${ }^{a}$ Isabel Albiñana de Ferrer y D. ${ }^{a}$ Potenciana Albiñana, mujer de D. Juan Sanz de Señera, venden al Cabildo de Játiva un censal originalmente cargado en 1576 por la ciudad a favor de Pedro Albiñana, ciudadano. ${ }^{132}$ Es razonable suponer que estas tres mujeres eran hermanas y, por lo tanto, que el hermano y sucesor del señor de Benemejís y Señera era yerno de la máxima acreedora del titular de estos señoríos, D. Jerónima Real.

Dejemos ya esta saga. Vinculaciones familiares también las podemos suponer con D. Baltasar Sanz de la Llosa -a quien ya hemos visto como uno de los síndicos de los acreedores- y D. Francisco Sanz de Alboy, aunque no pueda precisar el parentesco, y quizás con algún otro acreedor. Lo que parece evidente es que deudas y relaciones familiares están entremezcladas en el caso de D. Francisco Joaquín Sanz; y no es por casualidad: las donaciones inter vivos y los legados post mortem están en el origen de una parte de las deudas cuya significación no puedo evaluar.

Y topamos con la iglesia. El Cabildo de la Colegiata de Játiva, en sus distintas administraciones, es el segundo acreedor en importancia. No es de extrañar, los gruesos volúmenes conservados en el Archivo del Reino de Valencia evidencian su importancia como poseedor de censales que le hacen acreedor de individuos de la más variada procedencia social e instituciones. Son catorce censales, ninguno de ellos le reporta más de 20 libras al año y, en conjunto, 139 libras 15 sueldos 11 dineros. Gracias a las anotaciones de los citados volúmenes conocemos algo mejor su historia: salvo uno de los ocho identificados con mayor detalle, todos fueron cargados originalmente a favor del Cabildo; sus intereses se reparten entre el 6'7 y 7'5 por ciento; el más antiguo es de 1531 , seis se constituyeron entre 1559 y 1573 , y sólo hay uno más reciente, de 1593 , aparte de aquellos que ya habían sido quitados.

\section{III.- LA EXPULSIÓN DE LOS MORISCOS Y SUS INMEDIATAS CONSECUENCIAS}

Todo un mundo, el de una sociedad, la valenciana, caracterizada por la pervivencia de una importante minoría de origen islámico, se vio abocado a su traumático final con la expulsión de sus últimos representantes: los moriscos. Fue una decisión

130. Diego ZAFORTEZA y MUSOLES: «Historia de la fundación del Lugar Nuevo de Fenollet y de su señorío». Saitabi (Valencia), V1 (1948), pp. 5-47.

131. ARV: Real, $388, \mathrm{ff}^{\circ} 185 \mathrm{v}^{\circ}$ y ss.

132. ARV: Clero, libro 1.191, $\mathrm{f}^{\circ} 103 \mathrm{v}^{\circ}$, y libro $3.756, \mathrm{f}^{\circ} 287 \mathrm{v}^{\circ}$. 
discutida y aplazada una y otra vez, pero, aprovechando una favorable coyuntura en la escena internacional y queriendo exorcizar fracasos y fantasmas, entre otros factores, se acabó por tomar: el real decreto que disponía la expulsión de los moriscos se hizo público en Valencia el 22 de octubre de 1609 y en los días siguientes en las distintas localidades del reino. ${ }^{133}$

Los moriscos apenas tuvieron tiempo para embalar las pocas pertenencias que les permitieron llevar consigo e iniciaron el camino hacia los puertos desde donde serían embarcados hasta sus puntos de destino en el $\mathrm{N}$ de África. Las fuentes coinciden en destacar la sorpresa ante la «suavidad» de la expulsión, de una ausencia de conflictos que deberíamos matizar, pues los crecientes roces y la acumulación de agravios acabaron por estallar en un levantamiento a la desesperada cuando ya buena parte de los moriscos habían embarcado. Los sublevados, tras una resistencia fácilmente domeñada, siguieron los pasos de sus correligionarios en su tránsito hacía los puertos de embarque cuando ya los señores, los acreedores censalistas y los nuevos pobladores estaban pugnando por los despojos.

Las referencias a estos momentos en Benemejís y Señera son pocas, indirectas y a menudo interesadas, pues las encontramos en el corto debate librado entre el señor y los acreedores en torno al impacto de la expulsión, con el problema del pago de la deuda en el fondo. D. Francisco Sanz no habría estado durante los primeros momentos en sus señoríos defendiendo sus intereses y velando por la suerte de sus vasallos, sino que participó en la represión del levantamiento de los moriscos que se hicieron fuertes en la Muela de Cortes. Ello hizo que no pudiese obtener ningún beneficio del inmediato expolio al que fueron sometidos los moriscos y su ausencia, junto a las turbulencias del momento, permitió el saqueo de las cosechas pendientes (arroz y maíz) mientras los moriscos, a despecho de cualquier disposición, habrían malbaratado los bienes muebles y semovientes en detrimento de los derechos del señor.

No podemos precisar la fecha en la cual los moriscos de Benemejís y Señera abandonaron definitivamente sus hogares ${ }^{134} \mathrm{ni}$ el momento en el que llegaron quienes aspiraban a ocupar sus casas y tierras; quizás ambos coincidiesen como sucedió en tantos otros lugares. Pero la aplicación de tan drástica medida abría paso a un proceso de repoblación que resultó mucho más complejo que el de la expulsión en sí. Se ha hablado de que no faltarían candidatos para sustituir a los moriscos por el hambre de tierras que existiría en una sociedad que atravesaba por dificultades económicas, sobre todo en la manufactura, de que se abrigaron expectativas infundadas sobre un reparto generoso de los bienes de los expulsados entre quienes primero los ocupasen... Pero

133. Sobre el proceso que llevó a tomar la decisión, con sus incertidumbres, véase Rafael BENÍTEZ SÁNCHEZBLANCO: Heroicas decisiones. La Monarquía Católica y los moriscos valencianos. Institució Alfons el Magnànim, Valencia, 2001.

134. Es probable que embarcasen en el puerto de Denia, entre el 22 y el 24 de octubre, en quince navíos mercantes junto a los moriscos de localidades vecinas como Manuel y Rafelguaraf, entre otras (Henri LAPEYRE: Géographie..., pp. 57 y 79); aparte de los que pudiesen participar en la rebelión de la Muela de Cortes. 
pronto se impuso la cruda realidad: la munificencia de su católica majestad había concedido a los señores los bienes muebles y semovientes que no pudiesen llevar consigo sus vasallos moriscos; sobre todo, siendo el fisco regio el teórico beneficiario de los bienes confiscados a unos reos condenados sin juicio por el delito de lesa majestad divina y humana, también concedió a los señores los bienes inmuebles de los moriscos expulsados, tanto los que poseían en sus propios señoríos como, después, los localizados en el realengo, con algunas matizaciones.

Ante esta situación y las primeras exigencias señoriales se dieron ya tempranas defecciones, pero había una realidad y unos intereses en juego entre los cuales se imponía encontrar los puntos en común que permitiesen dar salida al problema planteado. $Y$ en este contexto urgía una negociación entre señores y nuevos pobladores, localidad a localidad y atendiendo a las pocas directrices emanadas desde instancias superiores. Unos tenían las tierras y otros hacían valer el argumento de que sin su trabajo poco valían, pero la negociación no era fácil y sí premiosa con el trasfondo de las reclamaciones de los acreedores y el riesgo de deterioro de las infraestructuras agrarias y los cultivos plurianuales.

Precisamente los síndicos de los acreedores denunciarán la supuesta falta de celo de D. Francisco Sanz en la gestión del proceso repoblador en detrimento de los intereses de sus representados, acusación generalizada en esos momentos y contra la cual reacciona el señor, pues

«es notorio la falta que de pobladores ha havido y hay en el reyno, en especial para lugares tan malsanos como son los de la çequia de las Énovas en donde se hazen arroses; y desde que faltan los moros se an despoblado tres vezes, por la qual razón haún no tiene segura aquesta parte su nueva población y tiene perdida para siempre la coxida del arrós, cuyos ayres hazen notable daño a la salut a los quales estavan coçidos los moros, dado que para ellos tubieran posibilidad y entelligencia los nuevos pobladores $\gg .{ }^{135}$

Este texto nos pone sobre la pista de una serie de cuestiones sobre cuya valoración diferirán señor y acreedores. Los arrozales aparecen, de forma más o menos explícita, como disuasorios para los nuevos pobladores, pero no se acaban ahí las dificultades; otra es la vieja cuestión sobre la capacidad de éstos en comparación con los moriscos. El señor no podía menos que loar la laboriosidad y la aptitud de los moriscos para justificar las pérdidas padecidas con su expulsión; los acreedores, por el contrario, destacan la feracidad de la tierra, con sus variadas cosechas,

«en las quales cosechas son destríssimos los christianos viejos, y assí sus cosechas han de ser no sólo las mismas que en tiempo de moros, pero ahún mucho más abundantes y benefficiosas si la otra parte, como ha tenido obligación, les ha repartido heredades competentes con las quales puedan bivir y animarse a trabajar para tener para sí y para pagar los derechos dominicales. Y ahunque de presente no stén las cossas con el assiento que antes de la expulsión y assí padescan algo de incomodidad, pero con el tiempo harán rayces y se

135. AHN: Consejos, 22.243/4, $\mathrm{f}^{\mathrm{n}} 77 \mathrm{r}^{\circ}$. 
afficionarán los pobladores con sus casas y heredades tratándoles, como es justo les traten los senyores, con todo gobierno christiano y de verdadero senyor a buen vassallo». ${ }^{136}$

En la discusión se insiste en las diferencias entre cristianos nuevos - «los quales, como es notorio, eran aficionadísimos a trabaxar y diestrísimos en semejantes cosechas»- y viejos - «lo qual no se puede dezir de los christianos» en opinión del señor--, tanto en general como refiriéndose en concreto a su conocimiento de determinadas técnicas de cultivo. En este terreno se habla de los daños en el arbolado «por no cultivarse dichos árboles por la poca intelligençia de los nuevos pobladores, falta de poder y deligencià; ${ }^{137}$ pero se llevan la palma las dificultades en los cultivos de arroz y maíz:

«y se ha de mandar advertir que las cogidas del arrós y daça se an de contar por pérdidas perpetuas por estar impucibilitados los nuevos pobladores de azerlas por el mucho trabajo, intelligencia y gasto que se requieren». ${ }^{138}$

«Porque se a de mandar advertir que la coxida del arrós es muy dificultosa y trabajosíssima por extremo y se a de gastar mucho en el conrreho y labor de aquella, por la qual razón están impucibilitados los nuevos pobladores de poderlo llevar, porque dado caso que entendiesen el dicho conrreho no tienen pucibilidad ni fuerzas para seguirle, mayormente que siendo de muy diferentes tieras si ay uno que entienda cómo se han de procurar y cultivar las heredades para la dicha coxida, los demás no lo entienden〉>. ${ }^{139}$

Vemos así aparecer otros elementos de juicio que también debemos tener en cuenta. No se trata sólo de diferencias de tipo cultural, casi moral, entre los cristianos viejos repobladores y sus predecesores moriscos, asimismo está su conocimiento de las prácticas agrícolas y sus recursos económicos. Por ello se insiste en que

«los nuevos pobladores, además de no tener posibilidad para comprar cavalgaduras, de las cuales se saca el estiércol tan necesario para las tierras, son poco entelligentes en ellas por ser la mayor partes officiales mecánicos y poco curiosos ansí en cultivar dichas tierras como el conrrear al agua, con la qual se riegan las de la huerta de dicho lugar, lo que no eran los moriscos, assí por estar muy azendados y tener muchas cavalgaduras como por estar destríssimos en la labor de dichas tierras y en entender el riego dellas»». ${ }^{140}$

Exageraciones y simplificaciones interesadas aparte, el desconocimiento de prácticas agrarias concretas y, sobre todo, del funcionamiento de unos sistemas de riego regulados consuetudinariamente podían dificultar la repoblación, pero también la falta de recursos económicos de los nuevos pobladores que se adujo hasta la saciedad por parte del señor. Antoni Albert, uno de los testigos de oficio, coincidía con él al declarar

«que sap molt bé les terres dels térmens de dit lloch han patit gran detriment per estar los olivars ab risca molt alta, y la horta mal procurada per no poder-se femar ni birbar per

\footnotetext{
136. AHN: Consejos, $22.243 / 4,1^{\circ} 55 v^{\circ}$.

137. AHN: Consejos, $22.243 / 4, f^{\circ} 76 \mathrm{r}^{\circ}$.

138. AHN: Consejos, 22.243/4, fn $78 \mathrm{r}^{\circ}$.

139. AHN: Consejos. 22.243/4, ff $73 v^{\circ}-74 \mathrm{r}^{\circ}$.

140. AHN: Consejos, 22.243/4, f" $71 v^{\circ}$.
} 
ser pobres los pobladors (...) y que lo dany serà llarch fins tant los pobladors estiguen arrahigats en la terra y tinguen amor a aquella». ${ }^{14 !}$

Ahora bien, en el texto antes citado aparece otra cuestión, la de los «oficiales mecánicos», la de si esa oferta de tierras extraordinaria había sido aprovechada por los hombres de una manufactura en crisis para encontrar solución a sus problemas, aunque fuesen poco duchos en las tareas agrícolas. Conocemos testimonios que hablan de ello con carácter general, ${ }^{142}$ pero sin poder precisar su importancia, también el de los acreedores en su lacónico último memorial, cuando dicen, contra lo aducido por el señor,

«que es notoria la general esterelidad que ha avido en los dos años antecedentes por todo el reyno, y es bien cierto que no las an causado la falta del cultivo ni la poca industria de los labradores, no consta que la otra parte haya solamente admittido por pobladores de sus lugares officiales mecánicos, antes bien lo contrario que ha excluido éstos y solamente dado las cassas y heredades a buenos labradores, y assí es muy frívola su impugnación y réplica) ${ }^{143}$

Los electos de los acreedores insistirán en que el señor no podía acudir, de forma indiscriminada, al comodín de atribuir las pérdidas a la poca pericia de los nuevos pobladores. Volveremos sobre ello al hacer el balance de la expulsión.

\section{L. - Las cartas pueblas}

Ahora bien, pese a todas las dificultades, se imponía dar estabilidad al proceso repoblador por los intereses que hemos comentado, sin olvidar las presiones desde instancias oficiales que querían ver pronto encauzada la situación. Dentro de las múltiples disposiciones promulgadas en esos momentos, no pocas veces confusas y contradictorias, ya hemos visto cómo el 12 de enero de 1611 se ordenó a los señores la repoblación de sus lugares despoblados en 6 meses y, acabado el primer plazo, el 15 de agosto siguiente se conminó a que lo hiciesen en 15 días; son las disposiciones que están en el origen inmediato del expediente que estamos utilizando. En el límite, D. Francisco Joaquín Sanz firmó con los respectivos nuevos pobladores las cartas pueblas de Benemejís y Señera. ${ }^{144}$

\section{AHN: Consejos, 22.243/4, fo $65 \mathrm{r}^{\circ}$.}

142. El testimonio más aducido es el de Damián Fonseca cuando habla de que dejaban «muchos de los que habitavan la ciudad de Valencia sus oficios mecánicos de sastres, çapateros, sederos y otros, por hazerse labradores»; quien tampoco es que tenga una opinión muy favorable sobre los nuevos pobladores, especialmente los que acudían a los lugares menos atractivos: «la gente que los ha de poblar, por la mayor parte ha de ser el desecho y escoria del mundo, que por no poder vivir en sus tierras han de buscar las agenas con mucha descomodidad» (cit. por Pascual Boronat y BARRACHINA: Los moriscos..., vol. II, pp. 344-345).

143. AHN: Consejos, 22.243/4, fo $88 \mathrm{r}^{\circ}$.

144. Sin duda, las gestiones del Dr. Salvador Fontanet fueron un aliciente importante para acelerar el proceso repoblador en muchas localidades y quizás forzase soluciones en falso. Tenemos distintas evidencias de ello en el Asiento de 1614, hasta el punto de que en Jaraco «apretó en que se hiziesse la población antes que él diesse la buelta a Valencia, y al fin se hizo el concierto y escritura con los pobladores que se hallaron a propósito» (Pascual Boronat y BarRachina: Los moriscos..., vol. II, p. 650). 
He hablado de cartas pueblas, en plural, cuando la bibliografía disponible habla sólo de una, la de Señera firmada el 11 de julio de 1611. Es la conocida tradicionalmente porque se conserva una copia en la sección Manaments y empares del Archivo del Reino de Valencia. ${ }^{145}$ La citan Sarthou Carreres y Martínez Aloy, ${ }^{146}$ con una referencia incompleta a su localización archivística, la fechan el 11 de junio y hablan de 21 nuevos pobladores. Sanchis Sivera supone la misma fecha y que sólo se repobló Señera, ${ }^{147}$ error que ha sido reproducido con posterioridad. ${ }^{148} Y$ esta carta puebla es la única localizada por Gual Camarena, ${ }^{149}$ también la única de este señorío que Ciscar Pallarés pudo incorporar al conjunto que estudió en su clásica obra ${ }^{150}$ y la única citada en una reciente y exhaustiva historia de la Ribera. ${ }^{151}$

Sin embargo, son tres las cartas pueblas que hemos podido consultar: la citada de Señera de 11 de julio de 1611 y dos referidas a Benemejís, de 11 de julio y 26 de agosto de 1611. ${ }^{152}$ Están firmadas por D. Francisco Joaquín Sanz, las tres, y catorce nuevos pobladores en el caso de la de Señera, siete en la primera de Benemejís y doce en la segunda. La primera pregunta que surge es cuál es la razón de firmarse tres cartas pueblas en tan corto lapso de tiempo. Es lógico que se firmasen diferentes cartas pueblas en Benemejís y Señera, pues, por poca entidad que tuviesen y perteneciesen a un mismo señor, no dejaban de ser señoríos diferentes y gestionados de forma independiente hasta tres o cuatro años atrás. Otra cuestión es explicar el por qué se firmaron dos cartas pueblas en Benemejís en apenas mes y medio, y no es fácil dar una respuesta. Encontramos ejemplos, como el de Benilloba, ${ }^{153}$ donde se firmaron sucesivas cartas pueblas en un plazo aún menor, hasta de sólo dos días, pero es que en Benilloba la segunda modificaba sustancialmente el contenido de la primera mientras que las dos cartas pueblas de Benemejís son idénticas en su desarrollo. Cabe pensar que los nuevos pobladores firmantes de la primera abandonasen el lugar atraídos por una oferta

145. ARV: $M E, 1697$, tomo 2, mano 18, $\mathrm{ff}^{\circ} 38 \mathrm{r}^{\circ}-48 \mathrm{r}^{\circ}$.

146. Carlos Sarthou Carreres y José Martínez Aloy: Provincia de Valencia. En F. Carreras Candí (dir.): Geografia General del Reino de Valencia. Casa Editorial Alberto Martín, Barcelona, s.f., vol. II, p.104.

147. José SANCHIS SIVERA: Nomenclátor..., p. 386.

148. Por ejemplo, en las entradas respectivas de la Gran Enciclopèdia Catalana. Enciclopèdia Catalana, Barcelona, 2001-2004 (12 ed.), vol. IV, p. 421, y vol. XXI, p. 71.

149. De su premiada recopilación de cartas pueblas sólo ha visto la luz póstumamente una colección de escuetas regestas, entre las cuales se encuentra la de Señera con el $n^{\circ} 281$ (Miguel Gual Camarena: Las cartas pueblas del Reino de Valencia (Edición de Desamparados Pérez Pérez). Generalitat Valenciana, Valencia, 1989, p. 186).

150. Eugenio Ciscar Pallarés: Tierra y señorio..., pp. 19 y 170.

151. Tomàs Peris Albentosa: Història de la Ribera..., vol. III, p. 293.

152. AHN: Consejos, 22.243/4, ff $21 \mathrm{r}^{\circ}-29 \mathrm{v}^{\circ}$ (Señera, 11 de julio de 1611), $31 \mathrm{r}^{\circ}-39 \mathrm{v}^{\circ}$ (Benemejís, 1 I de julio de 1611) y $41 \mathrm{r}^{\circ}-47 \mathrm{v}^{\circ}$ (Benemejís, 26 de agosto de 1611). Una copia simple del texto de los capítulos, exclusivamente, en ARV: Real Audiencia, Procesos, 1/F/1.256, ff' 108 y ss.

153. Elia GozÁlbez Esteve: El señorio de Benilloba. Obra Cultural de la Caja de Ahorros de Alicante y Murcia, Alicante 1985, pp. 35-38. 
mejor; de hecho, los firmantes de la segunda representaban un conjunto notablemente más numeroso y no coinciden los nombres de los repobladores de una y otra. Pero no es del todo convincente esta explicación, pues no se puede decir que el lugar hubiera quedado completamente despoblado, ya que los testigos de la segunda carta puebla eran Gaspar Vilar y Bartolomé Suau, firmantes de la primera (donde Bartolomé viene citado como «justitia et procurator») y ahora figuraban como «aratores, dicti loçi de Benimixix habitatores».

Entrando en el comentario de los documentos, es obligado destacar como, por las fechas de su firma, las dos primeras cartas pueblas apuran hasta el último día el plazo de seis meses dispuesto por la crida de 12 de enero de 1611. La segunda de Benimejís está fechada dentro de esa prórroga excepcional contemplada el 15 de agosto del mismo año. Parece como si las citadas disposiciones no fuesen ajenas a la decisión de firmar ya unas cartas pueblas que debían ser el exponente de haberse alcanzado la estabilidad y culminado el proceso repoblador, quizás dando una imagen ficticia. Por lo demás, el año 1611 fue en el que se firmaron un mayor número de cartas pueblas y, por la extensión de su articulado, se encuentran las de Benemejís y Señera en un término medio entre las contemporáneas. ${ }^{154}$

El contenido es casi idéntico en las tres cartas pueblas, sin apenas más diferencias que las de tipo ortográfico, y son de escasa significación, aparte, evidentemente, de los nombres de los nuevos pobladores, de los testigos y de las anotaciones marginales que identifican el contenido de cada uno de los capítulos y alguno de sus aspectos más relevantes; por ello, las pocas diferencias registradas deberán merecer una especial atención. El alto nivel de coincidencia entre todos los documentos es la razón por la cual, en el apéndice, sólo transcribo una de las tres cartas pueblas, y he optado por la de Señera porque parece ser la primera que se redactó y sirvió de modelo a las otras dos. Las referencias a su contenido, con el fin de no recargar las notas, las haré citando el capítulo correspondiente entre paréntesis.

En las cartas pueblas coetáneas suele contemplarse un amplio abanico de cuestiones, desde el derecho de patronato de las iglesias hasta otras de policía urbana o de regulación de la actividad agraria, pero siempre prestando una especial atención a los aspectos económicos: regalías y rentas agrarias, como más importantes, entre otros derechos de desigual significación.

Sin embargo, en las que comentamos, falta cualquier alusión al funcionamiento de la comunidad local: elección de los magistrados municipales, sus competencias, composición y facultades del consell... Son cuestiones habituales en las demás cartas pueblas valencianas firmadas esos años, ${ }^{155} \mathrm{y}$ en algunas tienen un notable desarrollo, de ahí que debamos destacar el silencio de las cartas pueblas de Benimejís y Señera. Así, aunque en la carta puebla de Señera uno de los nuevos pobladores se titule justicia y dos jurados, y que en la primera de Benemejís Bartolomé Suau aparezca como «jus-

154. Eugenio Ciscar Pallarés: Tierra y señorio..., pp. 174-175.

155. Eugenio Ciscar Pallarés: Tierra y señorio..., pp. 194-205. 
ticia et procurator» (ningún cargo figura en la segunda), debemos suponer que, como en otras localidades valencianas, ${ }^{156}$ tendrían un reducido ámbito de competencias y, en todo caso, sus actuaciones estarían estrechamente fiscalizadas por el señor, hasta el punto de que sólo podríamos considerar a estas localidades como municipios imperfectos, y quizás ésta sea ya una valoración generosa. De hecho, el señor se reservará el ejercicio de toda la jurisdicción que por Fueros le competiese y la facultad de promulgar las disposiciones que considerase oportunas, con la potestad de imponer las penas correspondientes a los contraventores (cap. 27).

El articulado dedica sus primeros capítulos a definir el marco general de las nuevas poblaciones. En el primero, el señor se comprometía a establecer a los nuevos pobladores la casa y tierras «que cascú de aquells té acomanada», con las condiciones pactadas en la carta puebla y la reserva de los derechos inherentes a la señoría directa. Son bienes que los beneficiarios se obligaban a cuidar y mejorar, especificándose después (cap. 10) que a su cargo quedarían las obras de mantenimiento y reforma de sus casas, las de conservación de «los portals, portes y portells» del lugar (cap. 25) y de las acequias, caminos y puentes del término (cap. 16).

En este primer capítulo es donde encontramos la única diferencia significativa entre las tres cartas pueblas. En la de Señera, el establecimiento se hacía con la salvedad de que en él no estuviese comprendida cualquier casa o tierra sometida a otro señor directo, salvedad que no se encuentra en las cartas pueblas de Benemejís. La situación en la que quedaban estos inmuebles era, de forma implícita, en subenfiteusis: el señor las encomendaba a los nuevos pobladores con las cargas contempladas en la carta puebla, mientras que él asumía el pago del censo correspondiente al señor directo. Ello lleva a pensar que sólo en Señera cabía semejante posibilidad, que podía dar lugar a interminables contenciosos, sobre todo con instituciones eclesiásticas; ${ }^{157}$ bien es verdad que ningún otro documento consultado alude a esa situación.

En un pequeño grupo de capítulos se regulaba la relación de vasallaje entre los nuevos pobladores y el señor. Era obligado avasallarse en el lugar prestando «los homenatjes de fidelitat acostumats», someterse al fuero y a la jurisdicción que le correspondería al señor por Fueros (cap. 3). Asimismo, los nuevos pobladores se obligaban a residir con su familia en Señera, sin poder ausentarse por más de seis meses del lugar, pena de comiso (cap. 4). En caso de querer abandonarlo, debían saldar cuentas con el señor antes de vender los bienes establecidos, con la condición de que el adquiriente no tuviese bienes censidos en Señera y se obligase a trasladar su residencia a la localidad en el plazo de dos meses, pena de comiso (cap. 4). Pero con una excepción: no podrían disponer de sus bienes en un plazo de cinco años, durante los cuales se obligaban a

156. Primitivo J. Pla Alberola: «Los municipios de señorío en el Seiscientos valenciano: a la búsqueda de un nuevo equilibrion. Mélanges de la Casa de Velázquez. Époque Moderne (París), tomo XXIX-2 (1993), pp. 108-110.

157. Un ejemplo local de lo conflictiva que podía llegar a ser la situación en Primitivo J. PLA AlBerola: «Los beneficios eclesiásticos y sus rentas a través de las visitas pastorales: la parroquia de Santa María de Cocentaina a principios del siglo XVIII». Anales Valentinos (Valencia), vol. 14 (1981), pp. 255-270. 
residir personalmente en el lugar, pena de perder los bienes establecidos; y también podría el señor expulsar a su entera libertad al nuevo poblador durante esos años, sin contemplarse en este caso ni la refacción de las mejoras (cap. 6).

Pero el mayor número de los capítulos está dedicado a los derechos económicos. En el séptimo se hablaba del luismo del 10 por ciento del precio del inmueble vendido y el medio luismo del 5 por ciento en caso de cargamento de censal. Después se recoge la obligación de utilizar los nuevos pobladores exclusivamente el horno, tahona, molinos, carnicería, taberna y tienda del lugar, pena de 60 sueldos; limitación que en la taberna y la tienda se circunscribía a las compras al por menor, al tiempo que tampoco podrían vender al por menor los artículos que se ofrecían en la tienda (cap. 8). Es una disposición que buscaba hacer rentables las regalías cuya explotación se reservó el señor, entre las cuales se incluían, aparte de las citadas, la almazara -a la que, además, se dedica un capítulo especial (cap. 14) - y el herbaje (cap. 9); y tal reserva se extendía a los árboles silvestres (cap. 26).

Con detenimiento se especifican los censos que debían satisfacer los nuevos pobladores, los cuales podemos dividir en dos grandes grupos: censos en dinero y en especie. Entre los primeros, con diferencia, el más importante es el censo de 7 libras anuales, pagaderas por mitad en las festividades de San Juan y Navidad, por cada lote de casa y tierras establecidas «com a çens, fadiga, lloïsme y tot plen dret enphitèotich segons Furs» (cap. 2). A él debemos añadir otros dos censos de menor entidad: los 2 sueldos por hanegada plantada de vides de uva de mesa (cap. 20) y los 10 sueldos por hanegada de alfalfa, hasta un máximo de dos, además de las tres hanegadas libres de cualquier gravamen para cultivos de autoconsumo (cap. 19).

Ahora bien, debemos suponer que el grueso de las rentas, como antes de la expulsión, estaba formado por las particiones de frutos, con sus ventajas e inconvenientes, pues en ningún momento se alude a un censo fijo en especie. Su configuración parece bastante sencilla: todos los cultivos de suelo -trigo, cebada, maíz, arroz, legumbres, lino, cáñamo y cualquier otro- partían al cuarto en el regadío y al sexto en el secano, entregando ya macerados lino y cáñamo (cap. 11), siendo también para el señor la cuarta parte de la paja (cap. 22); las vides cuyo fruto está destinado a la elaboración de vino, como cultivo de secano, asimismo al sexto, contemplándose la exención de siete años para las nuevas plantaciones (cap. 20); todos los cultivos arbóreos, fuesen de secano o de regadío, al tercio, quedándose el señor con el orujo tras la molturación de las aceitunas en la almazara (cap. 12), con el tronco de los árboles secos, más las ramas gruesas de los nogales (cap. 13) y con la tercera parte de la leña proveniente de la poda (cap. 18). Aunque sin contemplar ninguna exención, como la que hemos visto en el caso de las vides, también hay una apuesta clara por el fomento del cultivo de la morera, pues se obligaba a que los nuevos pobladores plantasen seis al año sin más límite que la voluntad del señor (cap. 15).

Hay toda una serie de disposiciones complementarias sobre dónde y cómo se debían satisfacer las particiones y otras que podían, incluso, servir para controlar posibles intentos de fraude. Era obligatorio trillar en las eras del lugar (cap. 24) donde presumiblemente se realizaría la partición de granos; la hoja se partía en el árbol y 
las aceitunas en la almazara (cap. 12). Con carácter general, la parte de la cosecha perteneciente al señor debía ser llevada por el nuevo poblador, de forma gratuita, a la casa o almacén señorial (caps. 11 y 12), aparte de hacer un pajar en las eras con la paja tocante al señor (cap. 22). Pero en el terreno de control, más importante si cabe era la libre designación señorial del guardián, cuyo salario se satisfaría «de tot montó en la hera», aunque sin especificar la cuantía (cap. 23).

Sin salir del terreno de los intereses económicos, también debemos mencionar la participación del señor en algunos costes, aunque pocos, además de la parte alícuota que le corresponde en el salario del guardián. El señor aportaría la viga de la almazara, cuya reposición en caso de ruptura se costeaba a medias (cap. 17), y también a medias se pagarían «les talles que's llançaran cascun any en lo porche del lloch de Ėnova» (cap. 21), tallas que presumo en relación con el mantenimiento del sistema común de riegos.

Hasta aquí el resumen de las disposiciones de las cartas pueblas de Benemejís y Señera. Debemos añadir que los acreedores en ningún momento cuestionaron las condiciones estipuladas, ni por considerarlas demasiado elevadas y disuasorias de la repoblación ni por entender que era exiguo el nivel de exigencias en detrimento de sus intereses; por omisión, podemos considerar que les parecieron adecuadas en un contexto sobre el que volveremos. También decir que en las cartas pueblas hay toda una serie de expresiones incorrectas y lagunas que enturbian su interpretación. Por ejemplo, se habla de «homenatjes de fidelitat» cuando el juramento de fidelidad y el homenaje son cosas distintas por más que vayan íntimamente relacionadas. Queda un tanto indefinido el carácter del censo de 7 libras -y es erróneo decir que se pagaba «per lo çens, fadiga, lloïsme de cada casa y heretat»-, aunque podemos considerarlo como una compensación de ese amplio abanico de cargas personales anteriores a la expulsión, y no se preveía qué pasará en el caso de enajenación parcial de los bienes establecidos o de repartirse éstos entre los herederos del nuevo poblador. Resulta arcaica la disposición que impedía vender los bienes censidos más que a forastero que se avasallase o a vecino sin tierras, pues parece como si el señor aspirase a mantener un número estable de heretats y que siempre estuviesen en manos de sus vasallos; es de suponer que sería un objetivo imposible de mantener ni a corto término aunque se viese refrendado por disposiciones posteriores de carácter general. Hemos comentado que el señor no percibía el tercio diezmo, pero tampoco se especifica si la parte señorial se detraía antes o después de diezmar, de pagarse diezmo, tercio diezmo y primicia; tampoco si antes de partir los granos se retenía una parte para simiente.

Pero ¿qué valoración podemos hacer de estas cartas pueblas, sobre todo en sus aspectos económicos? Cabe realizar una primera comparación con la situación vigente hasta pocos años atrás, en vísperas de la expulsión de los moriscos, y sin entrar ahora en las discusiones entre señor y acreedores. Las regalías son aproximadamente las mismas, otra cosa es su rentabilidad. Distinto es el caso de todos esos derechos que se antes se englobaban de forma un tanto confusa como besantes y azofras, incluidos los servicios personales: desaparecerán completamente, no existe la menor alusión a esas cargas que se identificaban como propias de una minoría sojuzgada, a no ser que en este capítulo queramos incluir la obligación de que los vasallos llevasen la parte de 
la cosecha correspondiente al señor donde éste indicase; pero nada equiparable a los jornales gratuitos o tasados, a contribuir los moriscos con su trabajo en el traslado de los enseres del señor, las hilazas, las adehalas, menos a la espaldilla de cordero que a «moro» tanto sonaba...

Atención especial merecen las particiones, pues suponían el capítulo más importante de los ingresos señoriales hasta 1609 y lo seguirán siendo con posterioridad. La tónica general es de disminución de la parte percibida por el señor: si era de la tercera parte de los cultivos de suelo en regadío y la cuarta en el secano (salvo en unas tierras menos productivas donde se partía al octavo), después de la expulsión la participación señorial quedó reducida a la cuarta parte de las cosechas en el regadío y a la sexta en el secano, sin mantenerse la diferenciación anterior, ${ }^{158}$ en el arbolado pasó de percibir la mitad (con la excepción de los higos al tercio, ya secos) a la tercera parte. Sólo parece ganar el señor en el caso de las vides, que sólo pagaban un censo fijo en dinero en Señera y ni se citan en Benemejís antes de la expulsión; después, el censo es de 10 sueldos por hanegada sembrada de alfalfa y 2 sueldos en la de uva de mesa, mientras el resto de las vides parten al cuarto.

Si llevamos la comparación al conjunto de cartas pueblas firmadas tras la expulsión, en Benemejís y Señera se pactó un plazo de residencia obligatoria medio, ${ }^{159}$ aunque sería tan inútil como todos los pactados entonces dada la fuerte movilidad de la población registrada en esos años en busca de las condiciones más favorables. Vemos que fue general la importante minoración cuando no la desaparición de los servicios personales, con las excepciones conocidas ${ }^{\mid 60}$ era un criterio extendido el que debían desaparecer y vino confirmado por la pragmática de 2 de abril de $1614 .{ }^{161}$ Las regalías eran las habituales en un señorío de tan reducida entidad. Como hemos visto no existían censos fijos en especie y en dinero, aparte de los que gravaban las tierras de alfalfa y de uva de mesa y el de 7 libras por heretat, que era el más alto de los establecidos en las cartas pueblas estudiadas por Eugenio Ciscar junto a Anahuir y Faldeta. ${ }^{162}$ Pero la cuestión que más nos debe interesar es la valoración de las particiones de frutos. Decir que son altas las exigidas en Benemejís y Señera, de las más altas del conjunto estudiado por el citado autor, pues era excepcional que se estipulasen particiones superiores a

158. Esta simplificación podría esconder un incremento del nivel de exigencias. Tengamos en cuenta que en 1445 se pagaba el cuarto «de fructibus qui sunt in orta dicti loci et non possunt rigari propter eorum altitudinem» y de «aliorum secanorum qui sunt de barranco castri versus planum Castillionis», y el octavo era «de fructibus secanorum dicit loci qui sunt a dicto barranco sursum muntaneam et retro muntaneam» (Primitivo J. Pla Alberola: «La carta puebla...», pp. 288-289. En vísperas de la expulsión, se pagaba la octava parte de los granos «que se cogían en las montanyas y tierra más áspera» (ANH: Consejos, 22.243/4, ff $2 \mathrm{v}^{\circ}-3 \mathrm{r}^{\circ}$ ), pero, para valorarlo adecuadamente habría que delimitar la distintas partidas y conocer las posibles mejoras en tan largo período de tiempo, especialmente en los regadíos.

159. Eugenio CisCar PALlarés: Tierra y señorio..., pp. 182-187.

160. Eugenio CISCAR PALLARÉs: Tierra y señorio..., pp. 269-271.

161. Pascual Boronat y BARRAChina: Los moriscos..., vol. II, p. 629.

162. Eugenio Ciscar Pallarés: Tierra y señorio..., pp. 237-245. 
las que hemos visto en estos lugares, y de nuevo vuelve a destacar el nivel de exigencias en Anahuir, ${ }^{163}$ un pequeño señorío ubicado también en el término de Játiva.

Ahora bien, con todo lo elevado que nos pueda parecer el nivel de exigencias, D. Francisco Joaquín Sanz estaba dentro de la más estricta legalidad e, incluso, puede deducirse que sigue las pocas recomendaciones hechas sobre el proceso repoblador. Algunas eran irreales, como la contemplada en un pregón de diciembre de 1609 de una partición máxima del quinto de la cosecha a favor de los señores, ${ }^{-164}$ otras más ajustadas a lo posible pudieron tener una mayor repercusión, como la contenida en un detallado informe de la Real Audiencia de fines de 1609: el censo máximo que se debería exigir por los frutos de los árboles sería del tercio de la cosecha, nunca la mitad, y en los demás cultivos debería ser menor a la vigente en tiempos de los moriscos, sin precisar su cuantía; añadiéndose que los nuevos pobladores deberían obligarse a fijar su residencia en los respectivos lugares durante cuatro años al menos. ${ }^{165}$ Vemos que las cartas pueblas de Benemejis y Señera encajaban en los criterios expuestos por la Real Audiencia, también con los que posteriormente definirá la Real Pragmática de 2 de abril de 1614: sustituir «las tandas, çofras y servicios personales» por «algunos censos moderados», aunque quepa cuestionar que lo sea el de 7 libras; prohibir la acumulación de bienes por algunos de los pobladores y permitir sólo su venta a forastero que se avasalle en el lugar. ${ }^{166}$

\section{III.2.- Las nuevas explotaciones}

Ya hemos visto cómo en los primeros capítulos de las respectivas cartas pueblas el señor se comprometía a establecer «ab acte públich» la casa y tierras, de secano y regadío, «que cascú de aquells té acomanada», con las condiciones detalladas en los siguientes capítulos y con la reserva de los derechos inherentes a la señoría directa. Pero no constaba ninguna otra indicación sobre las características de las explotaciones en esos documentos.

En el expediente que comentamos deberíamos encontrar respuesta a los temas que aquí nos interesan, pues en el pregón hecho publicar por D. Salvador Fontanet de 15 de julio de 1611 se exigía, entre otros documentos, «certificatòria de notari públich del repartiment que hauran fet de les cases y terres de dits llochs y térmens de aquells, especificant y declarant los noms de les persones y les porcions ab que hauran fet dit repartiment». ${ }^{167}$ Sin embargo, la documentación relativa a los habituales establecimientos inmediatos a la firma de las cartas pueblas no aparece con el detalle requerido, y no he podido localizarla en otro lugar. En él sólo se incluyen unas certificatorias del notario ante quien pasaron las cartas pueblas y, presumiblemente, los establecimientos,

163. Eugenio Ciscar Pallarés: Tierra y señorío ..., pp. 25 1-269.

164. Pascual Boronat y Barrachina: Los moriscos..., vol. II, pp. 238 y 567-568.

165. Eugenio CISCAR PaLlarÉs: Tierra y señorio..., p. 151.

166. Pascual Boronat y Barrachina: Los moriscos..., vol. If, pp. 629-630.

167. Pascual Boronat y Barrachina: Los moriscos..., vol. II, p. 607. 
donde, dirigiéndose de forma expresa al Dr. Fontanet, exponía cómo, en el día de la fecha (1 de marzo de 1612), D. Francisco Sanz

«ha fet to establiment particular a tots los vehins y pobladors del lloch de Seniera, donant e asignant a cascú de aquells casa y heretats, així en la horta com en lo secà del territori de dit lloch de Seniera. En lo qual establiment y repartiment particular se han asignat e donat a cascú de dits nous pobladors de dit lloch pus de vinticinch fanecades de terra de rech y horta y pus de quatre jornals de llaurar, olivars, vinyes y terra campa».

En un documento similar apenas cuatro días posterior se refería a los establecimientos de Benemejís, aunque las cifras son algo distintas: 20 hanegadas de huerta y regadío y 3 jornales de secano, sin mencionar que incluyesen viñas. ${ }^{168}$ Es decir, casi la misma cantidad de secano que de regadío en ambos lugares y unas explotaciones de 3'2 Ha en Benemejís y 3'8 Ha en Señera. ${ }^{169}$

Estos documentos apuntan a un reparto igualitario de las tierras entre los nuevos pobladores de Benemejís y Señera, sin indicar en ningún caso cuántos eran los benefíciarios, pero su comparación con las heretats de otras repoblaciones viene lastrada por las diferencias de calidad de las tierras en el campo valenciano. Desde luego, las explotaciones de Benemejís y Señera eran mucho más reducidas que las de Benillup o el marquesado de Guadalest, ${ }^{170}$ por ejemplo, pero aquí las tierras eran de secano y la huerta tenía muy poca importancia. La comparación es más real tomando como referencia lugares repoblados de la Huerta de Gandía u otros donde la huerta tuviese una fuerte presencia; $;{ }^{171}$ entre ellos, las extensiones establecidas en Benemejís y Señera resultan generosas y amparan el criterio del señor de que eran «muchas y bastantes para qualquier labrador $\gg .{ }^{172}$

Ahora bien, llama la atención la fecha de los documentos, pues hablan de unos establecimientos siete meses posteriores a la firma de las cartas pueblas. La falta de una relación nominal de los beneficiarios de estos establecimientos impide comprobar si coincide o no con la de los firmantes de las cartas pueblas. Quizás difiriesen bastante, es una pura especulación, pero sólo puede explicarse esta dilación recordando el testimonio antes citado del señor, cuando dice, en un memorial que debemos fechar un año después de la firma de las cartas pueblas (es posterior a junio de 1612), «desde que

168. AHN: Consejos, 22.243/4, respectivamente $\mathrm{ff}^{\circ} 51 \mathrm{r}^{\circ}$ y $48 \mathrm{r}^{\circ}$.

169. Tomando, dentro de la relativa incertidumbre de esta unidad de medida, el jornal de 6 hanegadas y 0’4987 Ha. Sobre estas cuestiones véase Concepción DOMINGO PÉREZ: «Nota sobre medidas agrarias valencianas». Estudis (Valencia), nº 9 (1981-1982), pp. 7-13. Con carácter más general, Claudi ALSINA, Gaspar Feliu y Lluís MARQuet: Pesos, mides i mesures dels Pä̈sos Catalans. Ed. Curial, Barcelona, 1990.

170. Primitivo J. Pla Alberola: «Benillup 1609-1630: alternativas y dificultades de una repoblación». Anales de la Universidad de Alicante. Historia Moderna (Alicante), $\mathrm{n}^{\circ} 1$ (1981), pp. 179-180 y 183 185; del mismo autor, La población del marquesado de Guadalest..., pp. 45-51.

171. Eugenio CisCar Pallarés: Tierra y señorío..., p. 178.

172. AHN: Consejos, 22.243/4, fo $75 \mathrm{r}^{\circ}$. 
faltan los moros se an despoblado tres vezes, por la qual razón haún no tiene segura aquesta parte su nueva población»». ${ }^{173}$

Hay otras cuestiones que también deben merecer nuestra atención: ¿hubo establecimientos de favor $u$ otras enajenaciones de inmuebles al margen del marco establecido por las cartas pueblas como se denuncia tan a menudo? ¿se repartió toda la tierra o el señor se reservó parte de la misma a su entera disposición, bien para gestionarla personalmente o bien para establecerla con posterioridad?

Las fuentes guardan un absoluto silencio sobre la primera cuestión, un silencio que podemos considerar significativo y concluir que no hubo irregularidades queriendo obtener el señor una inmediata rentabilidad o satisfacer deudas particulares al margen del resto de los acreedores. Sobre la segunda, recordar que existía en Señera, no en Benemejís, una tierra plantada de viña que el señor explotaba directamente, utilizando para su cultivo los servicios personales a los que estaban obligados los moriscos, según reconoce el propio señor; pero también que la reserva señorial se extendería a otras tierras que «olvida» mencionar. En las cartas pueblas sólo consta que el señor se reservó los árboles silvestres, pero no se mencionaba tierra de cultivo alguna. Los acreedores, no podía ser de otra forma, entran en la cuestión al defender que se podían aumentar las rentas del señorío tras la expulsión y criticaban que el señor no hubiese informado de las tierras establecidas «ni de las que quedan por repartir ni de las que se a reservado por cuenta propia», aludiendo a «lo que valen y rentan las vinyas, olivares, garroferales y morerales propios y las heredades que cultiva por cuenta propia». ${ }^{174}$

Los testigos coincidían en que el señor no se reservó tierras y que, incluso, los majuelos que tenía antes también los había establecido. En esa línea incidió después el señor, negando «se haya reservado por cuenta propia heredad alguna ni haun un palmo de tierra», aunque reconocía la excepción «de alguna que queda en los secanos yerma y que jamás se a cultivado, la qual no han querido ninguno de los pobladores». ${ }^{175} \mathrm{Como}$ apuntaban los testigos, hasta renunció a la reserva señorial que tenía en Señera plantada de viñas, por razones que nada tienen de filantrópicas sino producto de un estricto cálculo económico: eran viñas jóvenes, majuelos, y habían dejado de ser rentables al desaparecer los servicios personales de los moriscos, unos gratuitos y otros a un precio de tasa completamente desfasado, pues era el establecido siglo y medio antes en la carta puebla de 1445. El cálculo era bien sencillo: estimaba necesarios más de 200 jornales con un coste de 800 reales, pero, al pagarlos por tasa a 10 dineros cada uno, se ahorraba la nada despreciable cantidad de 68 libras 6 sueldos 8 dineros, el 90 por ciento de los salarios. ${ }^{176}$

$\mathrm{Si}$ aceptamos que el señor había repartido toda la tierra, la conclusión inmediata es que las explotaciones medias nacidas de la repoblación eran mayores que las de los

173. AHN: Consejos, $22.243 / 4, f^{\circ} 77 \mathrm{r}^{\circ}$.

174. AHN: Consejos, $22.243 / 4, \mathrm{ff}^{\mathrm{0}} 56 \mathrm{v}^{\circ}, 61 \mathrm{v}^{\mathrm{o}}$ y $62 \mathrm{v}^{\circ}$

175. AHN: Consejos, 22.243/4, $\mathrm{ff}^{\mathrm{0}} 71 \mathrm{v}^{\circ}-72 \mathrm{r}^{\mathrm{o}}$.

176. AHN: Consejos, $22.243 / 4, \mathrm{ff}^{\circ} 69 \mathrm{v}^{\circ}, 75 \mathrm{v}^{\circ}, 78 \mathrm{r}^{\circ}$ y v $\mathrm{v}^{\circ}$ y $82 \mathrm{v}^{\circ}-83 \mathrm{r}^{\circ}$. 
moriscos. Es una situación también documentada en otras localidades, como Chella y Turís, donde todas las tierras estaban establecidas entre un menor número de vasallos que en tiempos de los moriscos, y ello llevaba a que fuese imposible atraer más repobladores. ${ }^{177}$ Una variante la encontramos en las localidades donde se habían repartido todas las huertas y nadie quería ir a recibir sólo tierras de secano. ${ }^{178}$ En ambos casos, necesariamente, habría una menor disponibilidad de mano de obra, lo cual, unido a la falta de animales de labor y otros medios técnicos por la escasez de recursos de los pobladores, no podía menos que llevar a un menor rendimiento por unidad de superficie, aunque aumentase por unidad de trabajo invertido.

Sobre estos aspectos es interesante recoger el testimonio de D. Francisco Joaquín Sanz, con todas las reservas que queramos mantener:

«Los nuevos pobladores (...) estimarán más acudir a las coxidas que con menor gasto saquen dellas el sustento de su cassa y familia».

«Ś́lo procurarán las tierras que con menos trabajo puedan alcansar de haquellas su sustento y a causa de su poca pucibilidad de mucho tiempo no podrán cultivar todas las tierras establesidas, por ser muchas y bastantes para qualquier labrador» ${ }^{179}$

Todas las circunstancias aludidas pudieron incidir en modificaciones del paisaje agrario, aunque el corto período observado y las fuentes no permitan ir muy lejos. ${ }^{180}$ ¿Cabe que los nuevos pobladores primasen la producción de autoconsumo? Es una posibilidad que hemos visto apuntada por el señor, pero nada más podemos decir. Los memoriales del señor también mencionan algunos cambios en los cultivos a la hora de justificar las pérdidas sufridas, que atribuía a la falta de experiencia e interés de los nuevos pobladores y los costes de determinados cultivos. Sobre todo insistió en estos temas en el segundo memorial, en el momento de rebatir los argumentos aducidos por los acreedores contra el primer balance presentado.

En esos memoriales se habla de daños en el arbolado por falta de los adecuados cuidados en unos momentos de inestabilidad, quedando especialmente dañada la producción de hoja «por ser las moreras árboles muy delicados y de mucho regalo», aparte de «averse quemado mucha parte de las algarrovas» por las incidencias climatológicas. ${ }^{|8|}$ Entre los cultivos anuales, los más afectados serían el arroz y el maíz. Disminuiría la producción de arroz por las dificultades de su cultivo, los costes y porque «por causar muchas enfermedades totalmente dexan de azerlo en muchos lugares». ${ }^{182}$ El maíz desaparecería porque «de daça de Indias no ha cogido dicho suplicante cosa alguna, ni espera coger de aquí adelante, por rasón que los nuevos pobladores

177. Eugenio Ciscar Pallarés. Tierra y señorio..., pp. 280-281.

178. Primitivo J. Pla Alberola: La población del marquesado de Guadalest..., p. 51.

179. AHN: Consejos, 22.243/4, respectivamente ffo $80 r^{\circ}$ y $75 r^{\circ}$.

180. Sobre la evolución de los cultivos en esta comarca, véase Tomàs PERIS AlBENTOSA: Història de la Ribera..., vol. 11, pp. 79 y ss.

181. AHN: Consejos, $22.243 / 4, f^{0} 74 \mathrm{r}^{\circ}$ y v $\mathrm{v}^{\circ}, 79 \mathrm{v}^{\circ}$ y $82 \mathrm{v}^{\circ}$

182. AHN: Consejos, $22.243 / 4, f^{\circ} 68 v^{\circ}-69 r^{\circ}, 73 v^{\circ}$ y $80 v^{\circ}$. 
christianos viejos no la comen y ansí no la siembran», olvidando su aprovechamiento como cultivo forrajero. ${ }^{183} \mathrm{El}$ señor lamentaba la pérdida de las cebollas, «pues desde que faltan los moriscos no se an echo, y hay muy pocas esperanças de que en adelante se hagan, porque an menester mucho estiércol para el conreo de aquellas». ${ }^{184}$ Asimismo deploraba la disminución de tierras de alfalfa, «las quales no tanto importavan por lo que de aquellas se sacava como por lo mucho que fertilisavan las tierras y preparavan para las demás coxidas» ${ }^{185}$

Por otro lado, en las cartas pueblas se potenciaba el cultivo de la morera y de las viñas, pero el señor esperaba poco de ello, al menos a corto término, y por similares razones. Las moreras, «porque, además que dichas moreras de mucho tiempo no resarsirán el daño con los frutos que rendirán, los dichos nuevos pobladores no están en pusibilidad de poderlas cultivar ni labran»; las vides, «porque de muchos años no pueden rendir cossa que sea de subcistencia, en casso que dichos pobladores tuvieran pucibilidad, ansí para plantarlas como para cultivarlas, y es notorio (...), y los que entienden de agricultura saben muy bien, quán costoso es el conreo y labor de dichas viñas». ${ }^{186}$

Hasta aquí el análisis de los memoriales y la documentación que se presentó ante el comisario regio, y no podemos aportar otra para la mayor parte de las cuestiones abordadas. Sin embargo, un arrendamiento de $1618^{187}$ nos permite cuestionar algunas aseveraciones que parecian concluyentes, sobre todo en la cuestión de si el señor había establecido a favor de los nuevos pobladores todas las tierras cultivables o reservado algunas para gestionarlas directamente. En el documento se dice que el arrendatario percibiría las rentas de las tierras que tenía el señor «arrendades dins terme de la Vilanova de Castelló» (cap. 16): entre ellas se encontrarían tanto tierras poseídas desde antes de la expulsión por los señores de Benemejis y Señera como las que pasarían a sus manos, favorecidos por la decisión del monarca, que habrían pertenecido a sus vasallos moriscos. Otro capítulo aludía, de forma indirecta, a las dificultades de la repoblación:

"Ittem, és estat pactat, avengut, transigit y concordat entre les dites parts que totes les cases y heretats vacants en los dits llochs de Seniera y Benimixix, respectivament, sien de dits arrendadors durant lo temps de dit arrendament; y si acàs dits arrendadors les voldran poblar, sia y haja de ser a gust del senyor de dits llochs» (cap. 13).

183. AHN: Consejos, 22.243/4, fo $13 \mathrm{v}^{\circ}$. Una pérdida tan radical no la confirman los testigos, dos de los cuales estiman que el señor habría recibido 14 ó 15 barchillas o cahíz y medio ( 18 barchillas) de maiz

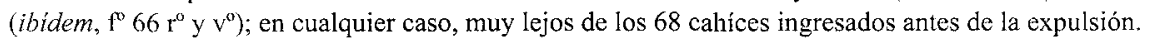

184. AHN: Consejos, 22.243/4, $\mathrm{f}^{\circ} 80 \mathrm{r}^{\circ}$.

185. AHN: Consejos, 22.243/4, fo $75 \mathrm{r}^{\circ}$.

186. AHN: Consejos, 22.243/4, $\mathrm{ff}^{\circ} 74 \mathrm{v}^{\circ}-75 \mathrm{r}^{\circ}$.

187. ARV: Real Audiencia, Procesos, 1/F/1.256. Se trata de un traslado notarial en cuarto que se cose al proceso entre el señor y los arrendatarios, foliado sólo en la camisa con el fo 54 ; las referencias al mismo las haré citando, entre paréntesis, el capítulo correspondiente. 
Este texto nos hace ver que la herida de la expulsión no era fácil de cerrar, y el ideal de permanencia de los nuevos pobladores en sus heredades fue imposible de conseguir. En otros capítulos se estipulan las labores agrícolas a que los arrendatarios quedarían obligados en olivares y viñas (caps. 8, 9 y 17), y ello lleva a sospechar que hay otras tierras bajo pleno dominio del señor, sospecha confirmada cuando el señor se reservó:

«en Seniera la heretat dita del Penyó, lo mallol y la vinya que està contigua a dit mallol, y en lo lloch de Benimixix se retura y reserva ver sí (...) la casa de senyor de dit lloch, lo ort, lo oliveral que-stà darrer lo ort, la heretat dels Rosers per los Campets ho Campillos que-stan entre lo olivar per el hort y per los olivars que-stan davall lo molí fins la sèquia del Almeller» (cap. 18).

Aparte, «se reserva y retura ver sí, sens comprendre's en lo dit arrendament, vint fanecades de vinya de vi en la vinya gran, a la part de les figueres, a sa electió» (cap. 19).

Es decir, D. Francisco Joaquín Sanz mantuvo el control de unas tierras cuya importancia no se puede menospreciar, siendo imposible determinar si la reserva señorial era más importante antes o después de la expulsión de los moriscos. Es razonable pensar que, en su momento, el señor no contempló el reparto de esas tierras entre los nuevos pobladores y desconocemos su posterior aprovechamiento; ahora bien, fuesen tierras abandonadas por los vasallos o parte de una reserva señorial de la que querría desprenderse el señor, lo cierto es que documentamos establecimientos de casas y heretats hasta 1667 con suculentas entradas de 47 y 90 libras. ${ }^{188}$

\section{III.3.- Las rentas señoriales tras la expulsión}

En el primer pedimento presentado por D. Francisco Joaquín Sanz, aparte de las cuestiones que ya hemos analizado, también enumera de forma individualizada, partida por partida, los ingresos recibidos tras la expulsión (Cuadro V); ${ }^{189}$ aparentemente, los ingresos de un solo año. ${ }^{190}$ Como hemos advertido, el documento no tiene fecha ni indica a qué año corresponden las cantidades recaudadas, pero ya hemos visto que debió presentarse en marzo de 1612 o poco después, por lo que debemos entender que se refiere a las cosechas de 1611, que parten según lo dispuesto en las cartas pueblas -aunque algunas se recogiesen poco antes de su firma- excepto en el caso de la morera, en el cual el señor se queda con la mitad de la cosecha en virtud del régimen provisional vigente hasta alcanzar el acuerdo que se vio plasmado en las cartas pueblas.

188. ARV: Protocolos de Domingo Trobat, 1667, sig. 10.373, $\mathrm{ff}^{\circ} 170 \mathrm{v}^{\circ}-184 \mathrm{r}^{\circ}$.

189. Existe un error evidente que no he considerado necesario corregir, pues es imposible que los 7 cahíces de trigo percibidos en Señera, a 60 reales el cahíz, valiesen 34 libras 10 sueldos.

190. Desconocemos cómo se estaba gestionando el señorío tras la expulsión, pues sobre el particular la única referencia nos la ofrece Antoni Albert, uno de los testigos de oficio, cuando dice «que los lochs són estats en secrest, que conforme les anyades que hi hagut se veurà per lo secrest que no se ha tret lo ters» (AHN: Consejos, 22.243/4, $\mathrm{f}^{\circ} 65 \mathrm{r}^{\circ}$ ). La documentación generada en tales circunstancias hubiese sido del mayor interés, pero en ningún momento se aporta ni se vuelve a hablar del tema. 
El primer aspecto que llama la atención es que se ha simplificado el número de partidas respecto a las documentadas antes de la expulsión. Ello es debido a la desaparición de muchos conceptos impositivos vigentes entre los moriscos y que los nuevos pobladores, identificándolos como cosa de «moros» y reivindicando su condición de cristianos viejos, se resistirían a aceptar; en general, las partidas incluidas bajo el epígrafe de besantes y azofras. Junto a éstas había otras que la nueva realidad no justificaba mantener y, en la consiguiente remodelación de las rentas, desaparecían. Son las que el señor llama pérdidas perpetuas. Pero otras partidas son fallidas de forma coyuntural, total o parcialmente.

\section{CUADRO $\mathrm{V}$ \\ RENTAS TRAS LA EXPULSIÓN DE LOS MORISCOS (INFORME SEÑORIAL)}

\begin{tabular}{|c|c|c|c|c|c|}
\hline \multirow{3}{*}{$\begin{array}{l}\text { PARTIDA DE } \\
\text { INGRESOS }\end{array}$} & \multirow{3}{*}{$\begin{array}{l}\text { PRECIO DE } \\
\text { REFERENCIA }\end{array}$} & \multicolumn{4}{|c|}{ INGRESOS } \\
\hline & & \multicolumn{2}{|c|}{ BENIMEJÍS } & \multicolumn{2}{|c|}{ SENERA } \\
\hline & & ESPECIE & DINERO & ESPECIE & DINERO \\
\hline Trigo & $60 \mathrm{r} / \mathrm{ch}$. & $4 \mathrm{ch}$. & $23-00-00$ & $7 \mathrm{ch}$. & $34-10-00$ \\
\hline Cebada & 4 s./b. & $3 \mathrm{~b}$. & $00-12-00$ & $3 \mathrm{~b}$. & $00-12-00$ \\
\hline Arroz & $22 \mathrm{r} / \mathrm{ch}$. & $3 \mathrm{ch}$. & 06-06-06 & $3 \mathrm{ch}$. & $06-06-06$ \\
\hline Algarrobas & 4 s./a. & $10 \mathrm{a}$. & $02-00-00$ & $10 \mathrm{a}$. & $02-00-00$ \\
\hline Higos & $7 \mathrm{~s} . / \mathrm{a}$. & n.c. & $06-00-00$ & $20 \mathrm{a}$. & $07-00-00$ \\
\hline Paja & 10 d./a. & $30 \mathrm{a}$. & $01-05-00$ & $60 \mathrm{a}$. & $02-10-00$ \\
\hline Hoja & $21 . / \mathrm{cg}$. & $60 \mathrm{cg}$. & $120-00-00$ & $100 \mathrm{cg}$. & $200-00-00$ \\
\hline Alfalfa & $5 \mathrm{~s} . / \mathrm{hg}$. & $60 \mathrm{hg}$. & $15-00-00$ & n.c. & $20-00-00$ \\
\hline Molino & Arrendamiento & & $60-00-00$ & n.c. & n.c. \\
\hline Panadería y tienda & Arrendamiento & & n.c. & & $02-07-11$ \\
\hline TOTAL & & & $233-13-06$ & & $275-06-05$ \\
\hline
\end{tabular}

Fuente: AHN: Consejos, 22.243/4, $\mathrm{ff}^{\circ} 7 \mathrm{v}^{\circ}-9 \mathrm{r}^{\circ}$ y $12 \mathrm{v}^{\circ}-14 \mathrm{r}^{\circ}$.

Abreviaturas: a., arroba; b., barchilla; cg., carga; ch., cahíz; hg., hanegada; r., real; s., sueldo. Las cifras en metálico están expresadas en libras-sueldos-dineros.

El señor no ingresó nada por el censo de 7 libras por casa y tierras ya que no estaban obligados a su pago hasta la firma de los nuevos establecimientos, ni por la vid, franca hasta entonces. Tampoco por un larga relación de legumbres y frutas, bien porque no se habían cogido o las habían consumido directamente los nuevos pobladores; aparte del lino y de que no hubiese partición de aceite ni derecho de almazara por ser un cultivo vecero y no haber dado cosecha ese año. Asimismo se habían logrado arrendar pocas regalías y a un precio irrisorio; la que más rentó fue el molino de Benemejís, pero a las 100 libras de su arrendamiento había que deducir 40 por reparos. Hasta aquí las pérdidas que en el documento se consideran temporales, sin que entre ellas se aluda a los luismos ni tampoco figuren ingresos por este concepto. 
Capítulo aparte merecen aquellas consideradas perpetuas, porque los nuevos pobladores no estarían obligados a satisfacerlas. Entre ellas están los censos por tierras plantadas de vides y cebollas, las espaldillas de carnero, las mejorías de higos y aceite, los celemines de habas y panizo, el derecho de alcaidía, las adehalas que sí se contemplaban en otras cartas pueblas, los besantes y, por supuesto, todos los servicios personales. Aunque se excedió, como hemos visto, al incluir entre las pérdidas perpetuas la partición de maíz.

D. Francisco no sólo ofreció unas cifras sino que, sobre todo en el segundo memorial, también introdujo factores de carácter cualitativo para explicar la realidad del momento a los que ya nos hemos referido: desconocimiento de los nuevos pobladores de las técnicas de cultivo y prácticas de riego propias de la zona, falta de recursos económicos... Todas las partidas de ingresos registraron una quiebra importantísima, cuando no es que desaparecieron: nada quedaba de besantes y azofras, las regalías valían un 87 por ciento menos... Centrándonos en las particiones, el señor habría perdido totalmente en 1611, por razones distintas, las 900 arrobas de aceite que ingresaría antes de la expulsión y las 1.025 libras que le reportaban, más los 68 cahíces de maíz valorados en 340 libras y las casi 400 libras de legumbres, frutas y lino, y no ingresaba nada de las viñas que ahora estaban sujetas a partición. Pero en los cultivos en los que sí había tenido ingresos las pérdidas son también más que notables, superiores al 80 por ciento y, a menudo, al 90 por ciento, con la notable excepción de la hoja de morera, en cuyo caso los ingresos señoriales se habrían visto reducidos «sólo» al 56 por ciento.

En total, y según las estimaciones del señor, apenas habría ingresado 233 libras 13 sueldos 6 dineros en Benemejís y 275 libras 7 sueldos 5 dineros en Señera. Cantidades absolutamente irrisorias respecto a las ingresadas apenas un par de años antes.

Ahora bien, estas cifras no las podían aceptar los acreedores. Si en su oposición al señor apenas habian cuestionado los planteamientos que éste hacía al hablar de las rentas anteriores a la expulsión o de las deudas que las gravaban, no cabía una actitud similar en este apartado, pena de plegarse a la conclusión de D. Francisco sobre que la magnitud de las pérdidas hacía inviable el pago de la deuda.

Los argumentos utilizados para oponerse a esas cuentas fueron varios y pretendieron desarrollarlos de forma detallada, por lo que, no teniendo datos concretos que enfrentar a los aducidos por el señor, intentaron construir su impugnación a partir de las rentas anteriores a la expulsión -en la medida que las aceptaban a beneficio de inventario- $y$ las cartas pueblas firmadas en 1611. Es decir, todos los datos que barajaban eran deducidos y les faltaba información concreta o la llegada a sus manos no les interesaba tenerla en cuenta porque no apoyaba sus planteamientos.

En un extenso memorial, los síndicos de los acreedores defendieron que las cartas pueblas contemplaban unos derechos netamente más favorables para el señor, en conjunto, que los que regían entre los moriscos: si dudan que el señor tuviese las tierras censidas antes de la expulsión ahora es indudable que sí lo estaban, con el provecho de los luismos; también habría ganado el señor al beneficiarse de unas regalías cuya existencia anterior cuestionaban - «los moriscos podían acudir a comprar las cosas de su comida adonde les parecía y no consta que dichas regalías fuessen de la señoría»- y 
cuya rentabilidad quedaría asegurada además porque «comiendo, comen más los christianos viejos que comían los moros»; en algunos derechos reconocían pérdidas, aunque no tanto como pretendía el señor, en todo caso compensadas por las ganancias en otros.

De ahí que insistiesen en la importancia del censo de 7 libras en sustitución del de 8 sueldos por casa (el señor pasaría de ingresar 264 sueldos a 4.620, habría «tresdoblado» sus ganancias), y, más adelante, que todos esos derechos incluidos bajo la denominación genérica de besantes y azofras apenas supondrían $33^{\prime} 5$ sueldos por casa y ahora cobraba el señor 7 libras por cada una de ellas... En cuanto a las particiones, la lógica que esconde sus muchos números era bastante sencilla: en el arbolado habría perdido un tercio y en los demás cultivos una cuarta parte, pérdidas deducidas exclusivamente de la comparación entre las particiones anteriores y posteriores a la expulsión.

Existieron otras impugnaciones en cuyo farragoso detalle no quiero detenerme: que si en las viñas habría ganado el señor, pues los moriscos pagaban un pequeño censo en dinero y ahora pagaban partición; que aumentaría la producción de hoja por las nuevas plantaciones a que se obligaban los repobladores... Si acaso reconocían un menoscabo coyuntural de las rentas, puramente fortuita, pues «si a sido injuria y inclemencia del cielo es cosa tan casual como en tiempo de moros y assí no proceden las cuentas que la otra parte quiere formar a su propósito (pero) es cosa que no tiene probabilidad ni puede haser regla para en adelante»>. ${ }^{191}$

De esta forma llegaban a su estimación de cuáles serían las rentas después de la expulsión. En un momento dado utilizaron los totales calculados por el señor para antes de la expulsión de los moriscos, pero al final prefirieron las más reducidas que resultaban de las certificatorias. «Admiten sin perjuizio de la verdad, en tanto quanto sean vistas haser y hagan y puedan haser a favor de los creedores censalistas, y no más, dissentiendo y contradixendo a todo lo contrario», que ambos señorios valiesen 4.664 libras 10 sueldos 2 dineros, por lo que «han de valer de presente y rentar los dichos lugares por lo menos» 3.109 libras 13 sueldos 6 dineros. ${ }^{192}$ La valoración de las rentas de 1611 hecha por los acreedores multiplicaba por seis a la ofrecida por el señor.

¿Y qué nos dicen los testigos? Los presentados de oficio entre el 8 y el 22 de junio de 1612 no ofrecen cifras alternativas, ni siquiera unas similares a las insuficientes que citaban para antes de la expulsión. Sólo nos transmiten algunos datos concretos, significativamente, los dos testigos que decían residir en Señera, aunque ninguno estuvo entre los firmantes de la carta puebla. Según Melchor Sanz, de 40 años, «en lo any passat sols vingué a la part de la senyoria» 11 cahíces de granos, 2 cargas de arroz y 1 ' 5 cahíces de maiz; Matías Dasi, de 60 años, nos dice que «de forment se cullgué lo any passat» 11 cahíces, 14 ó 15 barchillas de maíz, 2 cargas de arroz, 7 u 8 barchillas de cebada -habiéndose cogido «los anys ans» 15 ó 16 cahíces en cada lugar-y la hoja «ha menyscabat en tanta manera que no tindrá lo senyor a sa part en los dos llochs» 70

191. AHN: Consejos, 22.243/4, $\mathrm{f}^{\circ} 59 \mathrm{r}^{\circ}$.

192. AHN: Consejos, 22.243/4, f $62 \mathrm{r}^{\circ} \mathrm{y} \mathrm{v}^{\circ}$. 
cargas. Ambos testigos coincidían aproximadamente entre sí y no vale la pena detenerse en las diferencias con los datos del señor que no son unidireccionales. Los otros dos testigos de oficio no aportaban ninguna cifra sino sólo una apreciación muy personal, en la cual coinciden, y que quiero destacar: D. Acassi Sanz dice que «lo detriment és en tos los fruits y grans de tal manera que no arribarà al ters dels grans y fruits que's collien», para Antoni Albert «no se ha tret lo ters per estar tot perdut». ${ }^{193}$

En los posteriores memoriales no se aportaba mucho más a la valoración de las rentas tras la expulsión, al menos en cuanto a cifras concretas. En el segundo presentado por D. Francisco Joaquín Sanz, pese a ser bastante extenso, esencialmente defendía los datos que ya conocemos -agrupándolos con los mismos criterios utilizados por los acreedores para hacer más evidentes las diferencias que mantenía con ellos- y consideraba insubsistentes las críticas recibidas por la parte contraria. Reconoció la percepción del censo de 7 libras por casa que en su anterior memorial no habia hecho constar porque todavía no lo habría cobrado, pero criticó a los acreedores que utilizasen este censo como fácil comodín para compensar la pérdida de muchas partidas de ingresos. Pero sobre todo incidió en que no podían hacerse los cálculos en abstracto, como si nada hubiese pasado, que era irreal estimar los censos de antes y después de la expulsión como si el número de casas fuese el mismo, que tampoco cabía suponer que la producción agraria no se había visto menoscabada y aplicar sólo la reducción que resultaba de unas menores particiones, pues era muy inferior y especialmente importantes los daños en algunas cosechas; fue ahora cuando insistió, en los términos que ya conocemos, en la calidad del trabajo de los moriscos, en la falta de recursos de los nuevos pobladores... ${ }^{194}$

Ningún elemento concreto sobre estas cuestiones encontramos en el segundo y definitivo memorial de los representantes de los acreedores, sólo algunas consideraciones de carácter muy general...

\section{III.4.- A modo de balance}

Hemos visto que las posturas mantenidas por las partes eran muy distantes, especialmente a la hora de medir el impacto inmediato de la expulsión de los moriscos sobre las rentas de Benemejís y Señera, e irreconciliables por los intereses que encerraban.

Si nos atenemos a las cifras ofrecidas por D. Francisco Joaquín Sanz, con la expulsión de los moriscos habría perdido cerca del 90 por ciento de sus ingresos y, en consecuencia, con las magras 509 libras que le quedaban era absolutamente imposible pagar puntualmente los intereses de una deuda muy superior, menos aún si debía reservar para sí las cantidades que necesitaba como alimentos. Las de los acreedores divergían tan notablemente como ya hemos visto, por lo que llegaban a la conclusión, no podía ser de otra forma, que D. Francisco podía holgadamente y debía cumplir con 
el pago de la deuda, y todavía le quedaría una cantidad más que suficiente para vivir conforme a su condición.

Aproximarse a la realidad entre planteamientos tan dispares, con pocos medios de investigación y ante una situación tan cambiante, resultaba quimérico y uno tiene la impresión que Mateo Ferro, quien firmó el «Cálculo y bilanço del proçesso», ${ }^{195}$ hizo equilibrios para llegar a unos resultados aparentemente razonables que pudiesen estar lo más cercanos posibles a las posturas de las partes, aunque dar satisfacción a las dos fuese totalmente imposible. En primer lugar, aunque no lo ocupe en el documento, decir que Mateo Ferro desestimó la impugnación de los acreedores al conjunto de las actuaciones por haber presentado el señor fuera de plazo la documentación, pues «paresçe no ser de consideraçión porque con haverse presentado se purgó la nota».

Más allá, él era perfectamente consciente de sus muchas limitaciones y se impuso, desde un primer momento, un objetivo poco ambicioso:

«Se advierte que entre las asserçiones del señor de dichos lugares y los eletos de los censalistas ay notable distançia, por quanto el señor conçidera lo que existe y está en acto y los acreedores lo futuro y venidero, de lo qual ni ay sciençia ni cosa cierta, y assí ay difficultad en reduzir a concordia pretençiones tan distantes y encontradas. Sin embargo, se a procurado todo lo que ha sido posible ajustar el negoçio con toda la verosimilitud, de manera que se facilite en alguna manera la eleción del juez».

Las cifras que elevó a definitivas, con todas las reservas que manifiesta, las resumimos en el Cuadro VI. Detengámonos un poco más en cómo llegó a ellas. Cita siempre las estimaciones realizadas por D. Francisco Joaquín Sanz al hablar de las rentas señoriales antes y después de la expulsión de los moriscos, también de las deudas, pero no las aceptaba sin más, no podía aceptarlas y querer dar una imagen de imparcialidad, aunque se note su influencia en determinadas valoraciones. Para las rentas en vísperas de la expulsión se acogió al contenido de las certificatorias, sin reparar o sin querer reparar en que habían sido presentadas como prueba por el señor y en la exacta coincidencia con las cifras del memorándum señorial, salvo que no incluían una serie de partidas, algunas referidas a derechos contestados por los vasallos. Para apoyar su decisión adujo que las certificatorias venían confirmadas por los testimonios de D. Acacio Sanz y Antonio Albert, lo cual no deja de ser una falacia porque no coinciden exactamente más que en un par de cifras y difieren en las restantes, a veces de manera considerable. En el único apartado para el que disponía de fuentes alternativas era el de las deudas, y a ellas se atuvo para calcular su cuantía por considerarlas «verisímiles e indubitables».

Ahora bien, hemos visto que el caballo de batalla era el de las rentas tras la expulsión, donde las discrepancias entre el señor y los representantes de los acreedores resultaban irreconciliables, y Mateo Ferro lo sabía. Expresamente manifestaba tener en

195. «Cálculo y bilanço del proçesso hecho en Valençia sobre el valor de las rentas, frutos y drechos dominicales, cargos y censales de los lugares de Benemexix y Señera de antes y después de la expulsión de los moriscos». Cuadernillo de 10 páginas incluido en AHN: Consejos, 22.243/4, entre ff' 39 y 41. 
cuenta los memoriales presentados por las partes, «con sus presupuestos y pensamientos se ha visto minutíssimamente», para concluir

«que los eletos hazen la qüenta de dichos frutos presuponiendo que serán tantos y tales como eran en tiempos de moros y el señor se affirma con los que se han sacado effectivamente en los años 1610 y 1611 , lo que parece más çierto y verisímil considerando la ventaja que hazían los moriscos a los nuevos pobladores en el cuydado, intelligencia y poder y estar hechos a los ayres de los arroces, que son malsanos y no codiçiados de los nuevos pobladores. Y assí confiessan los dichos eletos en el fo 56 que de presente no están las cosas en el asiento que antes de la expulsión. Por tanto, se padesçe algo de incomodidad, la qual es muy evidente por lo que resulta del processo, y señaladamente por el daño que padesçen los frutos y árboles por no cultivarse como conviene y lo hazían los moriscos».

\section{CUADRO VI}

\section{EL IMPACTO DE LA EXPULSIÓN DE LOS MORISCOS, BALANCE OFICIAL}

\begin{tabular}{|l|c|c|}
\hline \multicolumn{2}{|c|}{ Ingresos en 1609: } \\
\hline Benemejís & & $2.043-03-08$ \\
\hline TOT̃era & & $2.621-06-06$ \\
\hline & & $4.664-10-02$ \\
\hline Deudas: & Propiedad & Intereses \\
\hline Censales del señor & $17.586-00-05$ & $1.322-07-03$ \\
\hline Censales de las universitats & $8.061-00-00$ & $637-00-00$ \\
\hline Censales de particulares moriscos & $68-10-00$ & $5-02-09$ \\
\hline Deudas sueltas & $1.595-16-03$ & $1.964-10-00$ \\
\hline TOTAL & & \\
\hline & & \\
\hline Ingresos en 1611: & & $1.554-13-04$ \\
\hline TOTAL & & \\
\hline
\end{tabular}

Fuente: AHN: Consejos, 22.243/4, «Cálculo y bilanço».

Las cantidades vienen expresadas en libras-sueldos-dineros.

Vuelve a ser decisiva la fuerza probatoria concedida por Mateo Ferro a los testimonios de D. Acasi Sanz y Antonio Albert sobre los daños generalizados atribuibles a la expulsión: para el primero, «lo detriment és en tots los fruits y grans,de tal manera que no arribarà al ters dels grans y fruits que-s collien»; para el segundo, «no se ha tret lo ters per estar tot molt perdut». ${ }^{196}$ El daño sería largo, el señor no se habría reservado tierras...pero lo importante es que Mateo Ferro convirtió esas estimaciones a vuelapluma, casi perdidas en el volumen del proceso y que no contenían siquiera los pobres datos concretos ofrecidos por los otros dos testigos, en la llave que abría la puerta de un callejón sin salida: el impacto de la expulsión supuso la reducción de los ingresos

196. AHN: Consejos, $22.243 / 4, \mathrm{ff}^{\circ} 64 \mathrm{r}^{\circ}$ y $65 \mathrm{r}^{\circ}$. 
señoriales a la tercera parte, «de tal manera que no llegarán los granos y frutos deste tiempo al $3^{\circ}$ de los que se solían coger antes». Así, de sumar antes de la expulsión 4.664 libras 10 sueldos 2 dineros quedaron para Ferro en 1.554 libras 13 sueldos 4 dineros, olvidándonos de algo más de 3 sueldos que se dejó por el camino. Problema resuelto, salvo que la cruel realidad evidenció pocos años después que los dos señoríos valían justo la mitad, entre 700 y 800 libras; cifras que hacían bueno el presagio del arzobispo Ribera a principios de 1610: la expulsión beneficiaría a los señores «que tenían los lugares a censo», incluso a quienes «los tenían a partición moderada», pero el señor de Benemejís y Señera estaría entre «los que tenían partición rigurosa, perderán en ella, porque los cristianos viejos no poblarán a ella». ${ }^{197}$

La conclusión de este «Cálculo y bilanço» era desoladora para los acreedores. Si el señor podía satisfacer sin ningún problema los intereses de su deuda hasta 1609 , tras la expulsión era una tarea totalmente imposible. La pérdida de 3.109 libras 16 sueldos 10 dineros, ${ }^{198}$ unido a que el señor veía incrementado su endeudamiento al tener que asumir el pago de los intereses de los censales cargados por las universitats de sus señoríos y de ese solitario censal al que respondía un morisco -las deudas sueltas quedaban ahí, sin más comentario, casi como una espada de Damocles-, hacía que el interés de la deuda superase a los ingresos en 409 libras 16 sueldos 8 dineros «sin los alimentos devidos al señor, gastos ordinarios de justiçia y gobierno que son inescusables». Desde otro punto de vista, el señor habría pasado de gozar de una holgada situación económica antes de la expulsión de los moriscos, al disponer de unos ingresos líquidos -deducido al pago de los censales a que estaba obligado- de 3.342 libras 2 sueldos 11 dineros, a no poder afrontar sus deudas ni tener los recursos mínimos para mantenerse y mantener a su familia.

La principal debilidad de este balance, supongamos bienintencionado, era la de otorgar un protagonismo decisivo al testimonio prestado por cuatro testigos de oficio, que los representantes de los acreedores debían haber impugnado como sospechosos de parcialidad: dos eran vasallos de la parte contraria, otro había sido arrendatario de Señera y del cuarto podemos suponer una vinculación familiar más o menos próxima con el señor. Pero no se produjo tal impugnación.

Ahora bien, rebobinemos y volvamos a las disposiciones que están en el origen de este expediente. En ellas se exigía que los señores como D. Francisco Joaquín Sanz, que pretendían reducción de intereses y tasación de alimentos, presentasen, entre otros documentos, relación pormenorizada de los bienes muebles e inmuebles de comunidades y particulares moriscos que habían pasado a sus manos y de cualquier otro ingreso que tuviesen. Y lo recordaron, quizás sin insistir demasiado en ello, los síndicos de los acreedores.

197. Eugenio Císcar Pallarés: Moriscos..., p. 197.

198. El documento cifra las pérdidas en 2.009 libras 16 sueldos 10 dineros, cuando las reales son 3.109 libras 16 sueldos 10 dineros, por un error aritmético en la diferencia entre 4.664 libras 10 sueldos 2 dineros (ingresos antes de la expulsión) y 1.554 libras 13 sueldos 4 dineros (ingresos después de la expulsión). 
En su respuesta, el señor insistía en que en nada se había beneficiado de la expulsión de los moriscos. Las cosechas pendientes se perdieron o fueron saqueadas y los bienes muebles de los moriscos se vendieron, nada se dice de los semovientes, y los testigos coincidían en que no participó en el expolio generalizado en esos momentos. Además, destacaba que todas las tierras cultivadas por los moriscos eran suyas, identificando abusivamente señoría directa y propiedad. ¿De verdad no se había beneficiado en nada de sus vasallos moriscos? La postura de los síndicos de los acreedores era bien distinta, aunque no tuviese una repercusión favorable a sus intereses:

«Porque es bien cierto que los moriscos no se llevaron la bondad del sitio de los dichos lugares, ni de sus huertas, secanos, plantados y distritos, ni el riego de sus tierras ni el influxo de los cielos ni las demás calidades naturales, no arrancaron los árboles y viñas, no arruinaron las huertas y barbechos, ni hizieron daños en las cassas y heredades, y sólo salieron sus personas pobres, sin halajas de casa, sin frutos y granos y sin las cosechas que quedaron pendientes, como eran las de arroz, adaccas, azeyte y otras de mucho valor y estima, sin los ganados y cavalgaduras, que en todo suscedió la otra parte (...).

Porque es cierto que los moriscos an deixado sus cassas y heredades mucho más mexoradas y augmentadas sin proporción que al tiempo que se las establecieron, y esto con su industria, trabaxo, sudor y hazienda, sin socorro y ayuda de la otra parte, y assí no puede pretender que no ha suscedido en bienes algunos de los moriscos, pues consta a notorio todo lo contrario... $\rangle^{199}$

Sin embargo, los moriscos también dejaron otros bienes que únicamente aparecían citados de pasada por el señor, y sólo cuando fue requerido por la parte contraria. La generosidad de su católica majestad había compensado a los señores por sus pérdidas con los inmuebles que sus vasallos poseyesen en el realengo, y D. Francisco no podía menos que referirse a esa concesión, aunque excusando la anterior omisión, cuando en su segundo memorial expuso cómo esas tierras estaban en manos del baile general y sus lugartenientes. ${ }^{200}$ Sería verdad, todavía esos bienes no estaban en sus manos, pues no sería hasta el 27 de julio de 1615 cuando el procurador de D. Francisco presentase la oportuna concesión real a favor de su representado de los bienes que sus vasallos moriscos tenían en el término de Villanueva de Castellón; ${ }^{201}$ quizás fuesen éstos los bienes valorados después en 625 libras. ${ }^{202}$

Pero iy de los demás bienes por los que se interesaba D. Salvador Fontanet? Podemos incluir en este apartado la reserva señorial y recordar que D. Francisco sólo reconocía un viñedo joven que había intentado hacer rentable con los servicios personales de sus vasallos moriscos y más tarde establecido entre los nuevos pobladores tras la expulsión; y hemos evidenciado que el señor no fue del todo sincero. Pero hay más, los síndicos de los acreedores preguntaron desde un primer momento por otros bienes

199. AHN: Consejos, 22.243/4, $\mathrm{f}^{\circ} 87 \mathrm{v}^{\circ}$

200. AHN: Consejos, 22.243/4, f $68 \mathrm{r}^{\circ}$.

201. ARV: Bailia, lib. 1.203, $\mathrm{ff}^{\mathrm{0}} 594 \mathrm{r}^{\circ}-600 \mathrm{v}^{\circ}$.

202. Eugenio CISCAR PALLARÉs: Tierra y señorio..., p. 309. 
del señor. D. Francisco hace una finta en la respuesta diciendo que ello sólo vendría a colación «en casso que en la presente instancia pidiera aquesta parte principalmente alimentos» cuando «en la presente instancia sólo pretende mostrar el notable daño y pérdida que ha tenido»; pero afirmaba de forma tajante «no posseher bienes algunos además de los dichos lugares». ${ }^{203}$

¿Había perdido las tierras que sus padres poseían en el vecino término de Villanueva de Castellón y que tantos problemas habían causado en el proceso de deslinde? ¿La última casa que poseía en Játiva era la vendida por el justicia a instancia de D. Olfo Sanz el 31 de enero de $16122^{204}$ Desde luego que no: seguía teniendo tierras en Villanueva de Castellón en 1618, como consta en el arrendamiento de ese año, ${ }^{205} \mathrm{y}$ sin duda otros bienes cuya existencia oculta. Los acreedores no se conformaron con su primera repuesta y en el segundo memorial insistieron, machacones,

«que en virtud de los reales edictos y provisiones tenía obligación de dar memorial verdadero de toda su hazienda y bienes, no solamente no les manifestó, antes bien ha celado con negativa expressa que sólo possehe los lugares de Benemexix y Seniera, siendo verdad que a más de las cassas que tiene y arrienda en Xátiva possehe otros muchos». ${ }^{206}$

Es ahora cuando los acreedores presentarán el único documento que exhibieron en el proceso: el certificado de los bienes dotales aportados por D. ${ }^{a}$ María Castellví y Fajardo a su matrimonio con D. Francisco Joaquín Sanz. Nada menos que 16.500 libras, incluidos un molino harinero y arrocero, con su casa y 9 hanegadas de moreral, sito en la huerta de Valencia, tres casas en Valencia, 5.745 libras en censales, ropas y joyas; ${ }^{207}$ le reportarían más de 500 libras de renta anual según los acreedores. Pero ya no hay más instancias y Mateo Ferro no tendrá en cuenta estos elementos de juicio a la hora de elaborar el balance.

Al actuar sin cumplir estrictamente las disposiciones publicadas por D. Salvador Fontanet, Mateo Ferro cometió un error más que beneficiaba a D. Francisco Sanz. Cuando se quiso dar solución a las pérdidas sufridas por los distintos señores afectados por la expulsión de los moriscos, se decía que «para no pedir alimentos basta que los dueños de lugares los tengan de dondequiera, aunque sea hazienda differente de lo que los lugares de moriscos les rentavan»; a los señores de Novelda les dejaron «sin señalarles alimentos, atento que no dio memoria de toda su hazienda, como estava obligado por los pregones hechos por orden del regente Fontanet». ${ }^{208} \mathrm{Y}$ a D. Francisco Joaquín Sanz le tasaron alimentos.

203. AHN: Consejos, 22.243/4, $\mathrm{f}^{\mathrm{D}} 72 \mathrm{r}^{\circ}$.

204. ARV: Clero, lib. 1.191, fo $74 \mathrm{r}^{\circ}$.

205. En el arrendamiento de los señorios de Benemejís y Señera se incluye la percepción de las rentas de «totes les heretats que'stan arrendades dins terme de la Vilanova de Castelló», sin indicar su extensión (ARV: Real Audiencia, Procesos, 1/F/1.256, f $\mathrm{f}^{\circ}$ 4, cap. 16).

206. AHN: Consejos, 22.243/4, $\mathrm{f}^{\circ} 87 \mathrm{r}^{\circ}$.

207. AHN: Consejos, 22.243/4, $\mathrm{ff}^{\circ} 85 \mathrm{r}^{\circ}-86 \mathrm{r}^{\circ}$.

208. Pascual Boronat y BARRAChina: Los moriscos españoles..., vol. II, pp. 640 y 642. 


\section{IV.- EPÍLOGO}

El expediente quedó formalmente cerrado con el balance firmado por Mateo Ferro, perdiendo la pista de su posterior discurrir por los vericuetos de la administración, y la investigación quizás no se contentase con expedientes como el analizado pues después se hablará de «papeles y averiguaciones» en el Asiento de 1614, sin concretarlas.

Podemos considerar que la investigación realizada por el Dr. D. Salvador Fontanet y su equipo culminó con el documento de 9 de junio de 1614, mediante el cual el monarca comunicaba «lo que he mandado resolver por consulta de la Junta, donde se ha tratado y trata de la composición y población desse reyno, cerca el assiento de las casas de los moriscos; para que cada uno de ellos vea y sepa lo que le toca y el remedio que se da a su casa» ${ }^{209} \mathrm{El}$ documento pasa revista a las situaciones que atravesaban los señores especialmente afectados por la expulsión de los moriscos, especificando caso por caso las medidas que, con carácter de excepción, se tomaban: reducción del interés de la deuda a que estaban obligados, asignación de alimentos a los más perjudicados.

En el caso de D. Juan Duarte, señor de Setla y Mirarrosa, se contemplaba la reducción a 20 mil el millar del interés de sus deudas, que con la rentas obtenidas de sus señoríos se pagase a los acreedores siempre y cuando le quedasen al señor 300 libras; de no ser así, se primaría el pago de esa cantidad al señor y el remanente se distribuiría a prorrata entre los acreedores. A continuación se dice:

«Lo mismo ha resuelto su magestad en quanto a la casa de don Francisco Sanz, cuyo se dize ser el lugar de Benimexix, con que como los alimentos que se han de tassar a don Iuan Duarte son de trezientas libras al año, sean para este cavallero de quatrozientas libras, por pedillo assí el estado en que se halla su hazienda». ${ }^{210}$

Sólo se habla de D. Francisco Sanz en su condición de señor de Benemejís, pero hemos visto que en el expediente utilizado no se diferenciaban las deudas aseguradas sobre Benimejís de las de Señera. Quizás sea una omisión nada más; en cualquier caso, había conseguido el objetivo que decía no perseguir: la asignación de alimentos. Sin embargo, es utópico pensar que con el Asiento se pondría punto final a los problemas relacionados con el endeudamiento de los señores, surgidos o agravados a raíz de la expulsión de los moriscos, pues se arrastraron durante décadas.

La documentación localizada no permite seguir adecuadamente el posterior desarrollo del conflicto de intereses entre el señor y los acreedores. Sabemos que el marco definido por el Asiento de 1614 se reveló pronto como absolutamente insuficiente y se intentó buscar mejor solución, apenas cuatro años después, mediante concordia firmada entre el señor y los representantes de los acreedores en 1618. ${ }^{211}$ En el preámbulo se exponía cómo las rentas de ambos señoríos habían valido «quant molt» 800 libras en

209. ASSIENTO de las casas de los títulos, barones y dueños de los lugares que por la expulsión de los moriscos del reynode Valencia quedaron despoblados. Pedro Patricio Mey, Valencia, 1614. En Pascual BORONAT Y BARRACHINA: Los moriscos..., pp. 636-657.

210. Pascual Boronat y BarRachina: Los moriscos..., p. 645.

211. ARV: Real, $388, \mathrm{ff}^{\circ} 185 \mathrm{v}^{\circ}-210 \mathrm{v}^{\circ}$. 
los anteriores años. Así, descontadas las 400 libras de alimentos asignados al señor y otras 200 libras por los costes de reparos tasados por la Real Audiencia, era imposible pagar los intereses de la deuda ni siquiera al tipo a que habían sido reducidos «però ni encara a diner per lliura».

En este caso los acreedores no cargaron las tintas sobre la gestión del señor, sino que reconocían

«que per molt que vulla esforçar-se lo dit don Francisco no li és posible fer més de lo que se ha acordat en los dits acrehedors (...) Y considerats los treballs que patix don Francisco per la ruïna dels dits llochs y depopulació de la mayor part de aquells, y per a que se anime y esforçe a reparar los dits llochs y mirar per sa hazienda sens respecte de que la millora que farà en dits llochs y hazienda la y han de ocupar sos crehedors».

Son las razones que forzaban el acuerdo, pues los acreedores vinieron a asumir que prácticamente sus créditos se habían convertido en incobrables y que la única forma de llegar a recuperar algo pasaba por firmar una concordia en la que rebajaban notablemente sus pretensiones, aprovechando además que el señor podía cubrir sus necesidades con un «asiento» del rey del que nada más se concreta.

$\mathrm{El}$ acuerdo era a largo término, contemplándose estrategias de actuación a un plazo superior a la década, con la pretensión implícita de que fuese definitivo. Los acreedores se conformaron con cobrar al 2'5 por ciento los censales cargados por el señor y al $1 ' 25$ por ciento los de las universitats de moriscos, y a contar desde el momento de la expulsión. D. Francisco depositaría en los diez años siguientes 500 libras anuales en la Taula de Cambis para pagar los intereses y 250 libras más a partir de entonces para luir progresivamente el principal de la deuda, renunciando por su parte a un número importante de derechos que tenía reconocidos sobre las rentas de sus propios señoríos. En los restantes capítulos se especificaba el procedimiento de luición, la prelación de deudas, el modo de gestión de los señoríos, las seguridades que ofrece el señor, la renuncia de los acreedores a los procedimientos abiertos, etc.

En virtud de lo acordado, el 16 de julio de 1618 se arrendaron los señoríos de Benemejís y Señera a Mateo Rugat y Francisco Rubí, menor, por 700 libras anuales y con la obligación de depositar 500 de ellas en la Taula o a disposición de la Real Audiencia para el pago de los acreedores; pero los arrendatarios rescindieron el contrato el 6 de diciembre de 1619. La situación no se encauzaba, las deudas se acumulaban en todas direcciones, y en las partidas de gastos se repetían como en una gravosa letanía 13 libras 10 sueldos 10 dineros "per lo salari de sentència», 15 libras 8 sueldos 5 dineros «per la sentència en forma y eixecutorials», 11 libras 4 sueldos «per les dietes de alguazir y notari y verguetes»...; $;^{212}$ con cada una de esas cantidades se podría haber satisfecho el interés de algunos de los censales que gravaban las rentas de Benemejís y Señera.

$\mathrm{Ni}$ aún así fue suficiente. Vemos de nuevo describir la situación en los términos más penosos al referirse a unos señoríos cuya población se había visto reducida a 14

212. Para todas estas cuestiones ARV: Real Audiencia, Procesos, 1/F/1.256. 
vecinos ( 13 en Señera, uno sólo en Benemejís) cuando en 1653 se modificó la concordia anterior, y el nuevo acuerdo supuso esencialmente que el señor asumía el compromiso de pagar las deudas al 2'5 por ciento y la renuncia de los acreedores a percibir los atrasos acumulados. ${ }^{213} \mathrm{Y}$ la documentación evidencia que el problema colea a fines de siglo.

La solución para que los señores de Benemejís y Señera tuviesen los ingresos suficientes para mantener el nivel que considerasen propio de su condición no pasaba, desde luego, por esperar a que mejorase la rentabilidad de sus señoríos. Desconozco qué gajes pudieron obtener, qué bienes les pudieron llegar por donaciones o herencias, el éxito de las alianzas matrimoniales de sus herederos, pero la situación de la fortuna familiar que podemos deducir a fines del siglo XVII no se basaba sólo en las rentas señoriales. Cuando en 1698 D. ${ }^{a}$ Josefa Sans de la Llosa, Alboy y Señera, señora de Benemejís y Señera, hizo, junto a su marido D. Alejandro Forner y Talayero, barón de Finestrat y señor de Benasáu, donación de 3.000 libras anuales a su hijo D. Jacinto Forner y Sans de la Llosa en contemplación de matrimonio, las aseguró por su parte sobre sus señoríos de Benemejís y Señera, desde luego, pero también sobre tierras en Villanueva de Castellón, un molino de papel blanco y otro para batir cobre con 22 hanegadas de huerta, casa, alquería y 400 hanegadas de huerta en Játiva con 40 horas de agua semanales, casa en Játiva, la mitad del jus scribendi del tribunal del justicia de 300 sueldos de Játiva, 18 jornales de olivos y algarrobos en Montesa, la parte que le tocaba del lugar de Ayacor, más distintos títulos y derechos. ${ }^{214}$

La renta señorial no era más que una parte, sin que podamos precisar su peso relativo en el conjunto de los ingresos. Años después, en 1724, más de la mitad de los ingresos de D. Jacinto, ya barón de Finestrat, procedían de inmuebles y censales, sólo cuando asumió la herencia de su madre las rentas de sus señoríos aportaron algo más. Es un ejemplo, como hace ver Jorge Catalá, de la importancia que en los ingresos de los señores pudieron tener otros que no proviniesen de sus señoríos y de los vaivenes que podían sufrir por el juego de las herencias. ${ }^{215}$

213. ARV: $M E, 1654$, libro 2, mano 14, ff $27 \mathrm{r}^{\circ}-43 \mathrm{r}^{\circ}$.

214. ARV: $M E, 1698$, libro 3, mano 32, $\mathrm{ff}^{\circ} 43 \mathrm{r}^{\circ}-48 \mathrm{v}^{\circ}$, y mano 33, $\mathrm{ff}^{\circ} 1-2$.

215. Jorge Antonio CATALÁ SANZ: Rentas y patrimonios de la nobleza valenciana en el siglo XVIII. Siglo Veintiuno de España Editores, Madrid, 1995, p. 63. 


\section{APÉNDICE DOCUMENTAL 216}

1611, julio, 11. Señera.

D. Francisco Joaquín Sanz, señor de los lugares de Benemejís y Señera, firma con 14 nuevos pobladores, labradores residentes en el lugar, la carta puebla de Señera, despoblado a raíz de la expulsión de los moriscos.

A - Archivo Histórico Nacional: Consejos, 22.243/4, doc. B, ff $21 \mathrm{r}^{\mathrm{0}}-29 \mathrm{v}^{\mathrm{o}}$.

B - Archivo del Reino de Valencia: Manaments y empares, 1697, tomo 2, mano $18, \mathrm{ff}^{\mathrm{0}} 38 \mathrm{r}^{\circ}-48 \mathrm{r}^{\circ}$.

[Camisa:] Acte d'establiment fet per don Françisco Joachim Sanz, senyor dels llochs de Seniera y Benimixix, als nous pobladors y vasalls del lloch de Seniera.

Die XI mensis julii anno a Nativitate Domini MDCXI.

In Dei nomine amen. Noverint universi quod ego don Franciscus Joachimus Sanz, nobilis, dominus locorum de Seniera et Benimixix, intra generales terminos civitatis Xative constructi, parte ex una, et Bernardus Marco, justiçia, Petrus Joannes Alventosa et Michael Marco, jurati dicti loci de Seniera, Martinus Tortosada, natu mayor, Petrus Martinez, Martinus Tortosada, natu minor, Christoforus Vidal, Sebastianus Glaudes, Joannes Ferraig, Petrus Rodrigues, Josephus Vanegas, Jacobus Garcia, Thomas Alventosa et Petrus Salezes, aratores, omnes residentes in dicto loco de Seniera, parte ex altera, uniti, convocati et congregati in platea et porta castri domini dicti loçi ubi pro negociis dicte universitatis dicti loci tractandis soliti sumus convocari et congregari. Quia de hordine et mandato domini nostri regis Philipi tertii, nuch feliciter regnantis, cum regia prachmatica publicata in presenti regno Valentie sub die vigessimo secundo mensis septembris anno a Nativitate Domini millessimi sexcentessimi noni fuerunt expulsi et banniti a presenti Valencie regno et Aragonis et a regnis Hispanie omnes sarraceni presentis regni que de causa dictus locus de Seniera fuit despopulatus. Eo quia vasalli, vicini et habitatores illius erant sarracenni et ita ego, dictus don Franciscus Joachimus Sanz, summa cum oppere totoque conatu tam pro conservacione jurisdictionis per Foros presentis regni michi tanquam domino dicti loci consese quam pro meo interesse et in dicto loco sucsessorum et creditorum dictum lo-//cum de perçonis incolis et habitatoribus christianis populare curavi et ita fuit yam populatum de predictis residentibus et cum sit justum dictas domos et terras dicti loçi stabilire et in enphiteutesim ( $\mathrm{sic}$ ) vobis suppradictis residentibus in dicto loci dare eo quia ipsas sufulquetis, cultivetis et in his laboretis et emolumenta redditus michi et sucsesoribus meis tanquam boni vasalli et enphiteutesi pareatis et solvatis conveni vobis cum de conservacione et stabilimento domorum, terrarum et aliarum rerum dicti loçi et michi domino illius pertinentium modo infra nominando et in capitulis inmediate sequentibus hispano sermone dicendis et declarandis in modum sequentem:

216. En la transcripción, he seguido criterios actuales en acentuación, puntuación y separación de palabras, indicando con punto volado las elisiones incorrectas. Las anotaciones marginales que identifican el contenido de cada uno de los capítulos se han integrado en el texto como sus repectivos epígrafes; existen otras anotaciones marginales, con distinta letra, de las cuales doy noticia en nota a pie de página. 
[1] Primo, és estat pactat, clos, avengut, transigit y concordat entre lo dit senyor del present lloch de Seniera, de una, y los nous pobladors y vasalls del dit lloch, de part altra, que lo dit don Francisco Joachim Sanz, senyor del dit lloch de Seniera, consedirà y establirà, segons que ab thenor dels presents consedeix y establix, a cascú dels dits pobladors la casa y heretat, així de rech com de secà, que cascú de aquells té acomanada en lo present lloch ab acte públich respectivament, a ben millorar y no deteriorar, ab lo çens de (sic) fadiga, lloïsme, pactes, càrrechs, particions dejús especificadors, returant-se dit senyor per a sí y a sos sucsessors tot lo dret de fadiga, lloïsme e tot plen dret enphitèhotich que conforme Furs del present regne los senyors directes se poden y dehuen aturar. No entenent enperò establir ninguna posesió, terra eo casa tenguda sots directa senyoria a ningun altre senyor directe, com les tals entenga dit senyor acomanar-les ab càrrech de les particions davall scrites a beneplàcit//de dit senyor y dels sucsessors en dit lloch y no en altra manera pagant dit senyor y sucsessors la ànnua penció als tals senyors directes si algú causa incogitada eo inopinada n’i hagués, no entenent en res ni per res difraudar senyoria directe ninguna.

[2] Çens perpètuo de 71 liures en Sant Joan y Nadal.

Ittem, és estat pactat, avengut y concordat entre lo senyor del dit e present lloch de Seniera, de una, y los dits nous pobladors y vasalls del dit lloch, de altra, que los dits nous pobladors e tots los sucsesors e vasalls en lo present lloch hajen y tinguen obligació de donar y pagar cascun any a dit senyor que hui és y per temps serà en los dies e festes de Sent Joan de juny y Nadal mijerament cascú de aquells perpètuament set lliures reals de Valènçia per lo çens, fadiga, lloïsme de cada casa y heretat pagadors, segons dit és desús, com a çens, fadiga, lloïsme y tot plen dret enphitèotich, segons Furs del present regne de València, ab lo qual çens se haja de fer e fassa lo dit stabliment.

[3] Homenatje y jurament de fidelitat.

Ittem, és estat pactat, avengut y concordat entre lo senyor del present lloch de Seniera, de una, y los dits nous pobladors y vasalls, de altra, que los dits nous pobladors se hajen de avasallar en lo present lloch de Seniera y prestar los homenatjes de fidelitat acostumats e segons los vasalls han acostumat prestar, sotsmetent-se al for y jurisdictió del senyor que hui és y per temps seran, en tant quant per Furs del present regne li és permés e lísit lo exercisi de la jurisdictió, així civil com criminal.

[4] Que se obliguen a residir en lo dit lloch.

Ittem, és estat pactat, avengut y concordat entre dit senyor del present lloch de Seniera, de una, y los dits nous pobladors y vasalls, de altra, que los dits nous pobladors y vasalls se hajen de obligar, per sí e sos sucsessors, a residir contínuament, ab son domiçili, casa y cap major, en lo dit//loch de Seniera y lo que faltarà per temps de mig any contínuo en dita residència perçonal encórrega en pena de comís de la casa y heretats que tindrà en dit lloch y son terme. Lo qual comís ipso facto sia fet sens haverse de fer prosés en forma de juhí ni altra solempnitat alguna.

[5] Que no se'n puguen anar que primer no conten e paguen al senyor.

Ittem, és estat pactat y concordat entre dit senyor del present lloch de Seniera, de una, y los dits nous pobladors y vasalls, de altra, que si per algun temps qualsevol 
de dits pobladors e vasalls e sucsessors voldran anar-se'n de dit lloch, primer e ans de totes coses, hajen de contar en lo senyor de dit lloch que hui és y per temps serà y pagarli lo que li deuran. Y, feta dita paga, tinguen facultat de vendre la dita casa y heretats a foraster eo a perçona de dit lloch que no tinga casa ni heretats; la qual venda no puga fer que primer lo dit comprador no se obligue a residir en dit lloch perçonalment, y dins dos mesos portar sa casa y avasallar-se en dit lloc, prometent residència perçonal sots pena de comís de les tals cases y heretats. De tal manera que, no fent-se en lo modo desusdit eo no venint dit nou comprador a dita residènçia perconal, passat lo dit termini dites casa y terres, sens ninguna forma de juhí ni prosés, resten comissades y la senyoria útil consolidada ab la directa.

[6] Hajen de residir 5 anys contínuos.

Ittem, és estat pactat, avengut y concordat que los dits nous pobladors se hajen de obligar ab lo dit acte de avasallament a residir perçonalment pert temps de cinch anys contínuos del dia de hui en avant contínuament contadors; passats los quals cinch anys puguen vendre, alienar y transportar les dites cases y terres en lo modo desusdit com a cosa pròpria de aquells y si ans de complits los dits cinch anys se'n aniran no puguen los dits vasalls //vendre, alienar ni transportar dites terres, ans bé aquelles resten de dit senyor per a fer-ne a ses llíberes voluntats sens ninguna interpel.lació ni forma de juhí. Dins los quals cinch anys estiga en llibera facultat del senyor de dit lloch despedir a qualsevols de dits vasalls ab causa llegítima.

[7] Çens de vendes y çensals.

Ittem, és estat pactat, avengut y concordat entre dit senyor del present lloch de Seniera, de una, y los dits nous pobladors y vasalls, de part altra, que de totes les vendes, alienacions y transportacions, particions y atre gènero de actes que s faran de dites cases y terres se hajen ${ }^{217}$ de pagar [a dit senyor que hui és y per temps serà lo llö̈sme] ${ }^{218}$ a dos sous per lliura y lo mig lloïsme a sou per lliura en cas de carregament, reservats los actes que conforme que conforme a forals dispositions no dehuen dret de lloïsme, sots pena comís.

[8] No puguen coure pa ni fer altres coses fora dit lloch.

Ittem, és estat pactat, avengut y concordat entre lo dit senyor del present lloch de Seniera, de una, y lo dits nous pobladors y vasalls, de altra, que dits nous pobladors y vasalls, vehins y habitadors del dit lloch de Seniera, que hui són y per temps seran, tinguen obligació de coure en $10^{219}$ forn del dit lloch lo pa y no en altre, conprar lo pa de la fleca de dit lloch y no de altra part aquell que hauran menester, estant en dit lloch, moldre tot gènero de grans y picar los arrosos en los molins de dit lloch, conprar carn aquella que hauran menester per a ses cases de la carniseria de dit lloch, lo vi de la taverna de dit lloch, lo qual vi tinguen obligació de comprar de dita taverna y no de

217. Al margen: «Luismo».

218. Texto restituido a partir de la carta puebla de Benemejís del 11 de julio de 1611 (AHN: Consejos, $\left.22,243 / 4, f^{\circ} 33 v^{\circ}\right)$.

219. Al margen: «Coçer en el horno". 
altra part alguna sent de mija quarta de vi en avall, y de mija quarta en amunt de hon voldran. Y axí mateix tinguen obligació de comprar totes vitualles y frasques, //com són totes vitualles de tenda y llegums de la tenda del present lloch de Seniera, entenentse de llegums de mig almut en avall y de mig almut en amunt puguen comprar tot gènero de llegums, com són siurons, faves, guixes, llentilles, arròs y altres llegums de hon voldran. Y axí mateix ningú sia gosat de vendre ni comprar dits llegums de mig almut en avall sinó és de dita tenda, y de ahí en amunt puguen comprar-los y vendre'ls com sien de ses collites pròpies. $\mathrm{E}$ assò se ha de entendre, en respecte de les regalies desús dites, havent-hi en aquelles y cascuna de aquelles respectivament lo recapte nesessari y conpetent y no en altra manera, sots pena de sexanta sous per cascuna vegada que contravendran.

[9] Reservació de regalies per lo senyor.

Ittem, és estat pactat, avengut y concordat entre lo senyor del dit lloch de Seniera, de una, y los dits nous pobladors, de altra, que lo senyor de dit lloch se retura e reserva ver sí y sos sucsessors les regalies y emoluments de molí, forn, almàsera, carniceria, tenda, fleca y taverna y lo herbatje de dit lloch.

[10] Obres de cases y conservació.

Item, és estat pactat, avengut y concordat entre los dits senyor del present lloch de Seniera, de una, y los vasalls nous pobladors del dit lloch, de altra, que los dits nous pobladors y los vasalls y sucsessors de aquells, que hui són y per temps seran en lo dit lloch, sien tenguts y obligats a fer les obres nesessàries en cascuna de les cases que aquells tindran per a la conservació y perfectió de aquelles y cascuna de aquelles com a bons vasalls y enfiteotes.

[11] Partiçió de fruits eo grans.

Ittem, és estat pactat, avengut y concordat entre lo senyor del dit e present lloch de Seniera, de una, y los dits nous pobladors y vasalls de dit lloch, de altra, que dits //nous pobladors y vasalls de dit lloch de Seniera, que hui són y per temps seran, perpètuament en dit lloch de Seniera hajen de partir y partixquen, ab lo dit senyor y ab los senyors sucsessors en dit lloch, tots los grans de forment ${ }^{220} \mathrm{y}$ hordi, dacsa, arròs y tot altre qualsevol gènero de grans y llegums, 11 , cànems y tot altre qualsevol gènero de collites y esplets de qualsevol espècie sien que's colliran en la horta y terres de rech de dit lloch, terme y territori de aquell al quart, ço és tres parts per al vasall ${ }^{221}$ y la quarta part per al senyor; y en lo secà a la sisena, ço és cinch parts per al vasall y la sisena per al senyor, posats dits fruits y grans, nets y com convé, en los graners de la casa del senyor per los dits vasalls francament y la partició de lli y de cànem amerat que sia al quart segons dit és desús.

[12] Partició de fruits de arbres.

Ittem, és estat pactat, avengut y concordat entre los dit senyor del present lloch de Seniera, de una, y los dits nous pobladors y vasalls, de altra, que dits nous pobladors

220. Al margen: «(¿?)ros, ordio, dacca, arrós y otro género de cosechas en el regadío al $4^{\circ} \gg$.

221. Al margen: «Secano al $6^{\circ} \gg$. 
y vasalls que hui són y per tems seran perpètuament en dit lloch de Seniera hajen de partir y partixquen ab lo dit senyor y ab $\operatorname{los}^{222}$ senyors y sucsessors en dit lioch tots los fruits dels arbres de qualsevol espècie sien, així en la horta com en lo secà del dit lloch de Seniera, al ters, ço és les dos parts per al vasall y la terçera part per al senyor, posada y portada la part del dit senyor dins la casa del senyor en son degut lloch y en los puestos ahon se acostumen posar per dits vasalls; dempto lo fruit de la fulla que se ha de partir en lo arbre y les olives se han de fer oli en la almàsera de dit lloch per dits vasalls, y la part tocant //al senyor així mateix se ha de posar y portar a la casa del senyor en les gerres y lloch acostumat francament y axí mateix sia tot lo pinyol de totes les olives y oli que s farà del senyor y los vasalls no tinguen ninguna part en aquell.

\section{[13] Partició del arbre sech.}

Ittem, és estat pactat, avengut y concordat entre lo dit don Francisco Joachim Sanz, senyor del dit lloch de Seniera, de una, y los nous pobladors y vasalls del dit lloch, de altra, que tostemps que en lo terme de dit lloch se secarà algun arbre, de qualsevol gènero sia, tinga lo senyor de dit lloch la soca y tronch y los vasalls y pobladors que hui són y per tems seran les rames. Asò emperò entés que, si serà noguer, sia la soca eo canya y tot allò que's porà serrar del senyor de dit lloch.

[14] Que no·s puga fer oli sinó en la almàsera del senyor.

Ittem, és estat pactat, avengut y concordat entre lo senyor del dit lloch de Seniera, de una, y los vasalls y pobladors del dit lloch, de part altra, que los dits vasalls y nous pobladors que hui són y per temps seran y los sucsessors tinguen obligació de fer e fasen tot lo oli prosuhit de totes les olives ques colliran en lo terme del dit lloch de Seniera en la almàsera del dit lloch y no en altra part, sots pena de perdició de olives y oli y altres penes a arbitre del senyor de dit lloch, posant y portant la part del oli al senyor pertanyent en lo modo que dit és desús en lo lloch acostumat dins la casa del senyor francament per los dits pobladors y vasalls que hui són y per tems seran.

[15] Que cascun poblador plante 6 moreres cascun any.

Ittem, és estat pactat, avengut y concordat entre lo dit//senyor de Seniera, de una, y los vasalls y nous pobladors del dit lloch, de altra, que cascun vasall y nou poblador del dit lloch, per sí e per sos sucsessors, tinga obligació de plantar y plante en la sua heretat cascun any sis moreres, comensant a plantar-les del any mil sis-cents y dosse (sic) en avant. $\mathrm{Y}$ axí tostemps perpètuament a beneplàçit del senyor que hui és e per temps serà en lo dit lloch de Seniera.

[16] Conservació de cèquies y ponts.

Ittem, és estat pactat, avengut y concordat entre lo senyor del dit lloch de Seniera, de una, y los vasalls nous pobladors del dit lloch, de altra, que los dits vasalls del present lloch de Seniera que hui són y per temps seran y tots los sucsesors de aquells residents y colents lo dit lloch tinguen obligació de escurar y netejar totes les cèquies, així majors com menors y brasals, y tenir en conreu aquelles, y axí mateix fer y conservar los ponts que hui són y los que convindran fer y sustentar en lo terme de dit lloch de

222. Al margen: «Frutos de árboles en regadío y secano al $3^{\circ} »$. 
Seniera per al serviçi de les heretats, camins e sendes del territori y terme de dit lloch a costes y despeses pròpries de dits vasalls, vehins y pobladors que hui són y per temps seran en lo dit lloch de Seniera.

[17] Lo senyor done la biga per a fer lo oli y si-s romp se adobe entre lo senyor y vasalls mijerament.

Ittem, és estat pactat, avengut y concordat entre lo senyor del dit lloch de Seniera, de una, y los nous pobladors y vasalls del dit lloch, de altra, que lo senyor de dit 1loch tinga obligació de donar a dits nous pobladors y vasalls de dit lloch la biga de la almàsera per a fer lo oli que's collirà en lo terme de dit lloch en aquella, lo qual no's puga fer en altra part si e segons ya és dit desús e sots la dita pena y penes. Assò emperò entés que tostemps que la dita biga de almàsera es romprà per alguns temps //se haja de adobar y conservar tantes vegades quantes se romprà a costes y despeses del senyor y vasalls del dit lloch que hui són y per temps seran mijerament.

[18] Que no's desimale sens llicència y partició de llenya.

Ittem, és estat pactat, avengut y concordat entre lo senyor del dit lloch de Seniera, de una, y los nous pobladors y vasalls del dit lloch, de altra, que ningú dels dits nous pobladors y vasalls del dit lloch que hui són y per temps seran gosen ni presumeixquen desimalar ni desimalen ninguns garrofers, olivera ni oliveres ni altre gènero de arbres, exsepto les moreres, sens llicènçia del senyor del dit lloch que hui és y per temps serà, sots la pena inposadora a arbitre del senyor de dit lloch. Y de la llenya que se haurà desimalat grosa y menuda trosejada y capolada que sia se n'hajen de fer tres eguals parts, dos per al vasall y la una per al senyor, triant lo senyor de les tres parts la que voldrà.

[19] Tres fanecades per a erba y refaçi.

Ittem, és estat pactat, avengut y concordat entre lo dit don Francisco Joachim Sanz, senyor del dit lloch, de una, y los vasalls nous pobladors del dit lloch de Seniera, de altra, que lo dit senyor del dit lloch dona y donarà ab thenor del present tres fanecades $^{223}$ de terra de rech en la horta de dit lloch a cascú de dits nous pobladors per a fer erba de alfals per a les cavalcadures de aquells y de cascú de aquells eo llegums y hortalises. Y si algú de dits vasalls no tindrà sufficient terra de dites tres fanecades, conforme les cavalcadures que tindrà, $\mathrm{y}$ haurà menester més terra ultra de les dites tres fanecades per a lo que dit és desús lo senyor de dit lloch darà al tal poblador eo vasall més terra, ab esta modificaçió: que no puguen ser ni exsedir de dos fanecades ensús ni puga fer-se en lo refassi de dita terra altra cosa sinó serà herba alfals, y dit vasall li haja de donar y pagar al senyor de dit lloch per cada fanecada ${ }^{224}$ de refassi, ultra de dites tres fanecades, deu sous per cascuna //fanecada cascun any, pagadors en lo dia e festa de Sant Miquel mentres posehirà dita terra de dit refassi, los quals deu sous se hajen de cobrar ab prompta y real execució com a béns de regalies de la senyoria de dit lloch.

[20] Partició de vinyes.

223. Al margen: «Fanecades de terra a cada uno».

224. Al margen: «10 sous cada fanecada ultra las $3 »$. 
Ittem, és estat pactat, avengut y concordat entre lo senyor de dit lloch, de una, y los vasalls nous pobladors de dit lloch, de altra, que los vasalls que hui són y per tems $\operatorname{seran}^{225}$ de dit lloch de Seniera tinguen obligació de partir les vinyes que tindran de verema ab lo senyor de dit lloch que hui és y per tems ${ }^{226}$ serà a la sisena part, y si serà vinya de planta dit vasall haja de pagar y pague dos sous per fanecada com a regalies de la senyoria a rahó de dos sous per cascuna fanecada. Y si algú de dits vasalls plantarà alguna vinya eo vinyes com dit és dins set anys no pague cosa ninguna per lo que haurà plantat y al huitè any comense a pagar en la forma desús dita, a saber és si serà eo seran de verema la sisena part y si seran de planta a dos sous per fanecada en lo dia e festa de Sant Miquel cascun any, ab que dites vinyes se hajen de plantar en lo secà y no en la horta de dit lloch.

[21] Que les talles sien mijeres.

Ittem, és estat pactat, avengut y concordat entre lo dit don Francisco Joachim Sanz, senyor del dit lloch de Seniera, de una, y los dits nous pobladors y vasalls del dit lloch que hui són y per tems seran, de altra, que les talles que-s llançaran cascun any en lo porche del lloch de Ėnova per la part que cascun any ne tocarà de talla al dit lloch de Seniera la dita talla y talles se hajen de pagar y paguen entre lo senyor y vasalls del dit lloch que hui són y per temps seran mijerament.

[22] Partiçió de palla.

Ittem, és estat pactat, avengut y concordat entre lo dit don Francisco Joachim Sanz, senyor del dit lloch, //de una, y los vasalls nous pobladors de dit lloch, de altra, que los vasalls del dit lloch de Seniera tinguen obligació de partir y partixquen perpetualment la palla prosuhida dels grans de forment y hordi collits en lo terme de ${ }^{227} \mathrm{dit}$ lloch així en la horta com en lo secà ab lo senyor de Seniera que hui és y per temps serà al quart, fent-ne quatre eguals parts tres per al vasall y la quarta part per al senyor. De tota la qual palla pertanyent a la part del senyor de dit lloch los dits nous pobladors y vasalls tinguen obligació perpètuament de fer-ne de aquella un paller per al senyor de dit lloch en les heres del lloch de Seniera francament, sens ningun interès.

[23] Lo senyor senyale guarda y es pague de tot montó en la hera.

Ittem, és estat pactat, avengut e concordat entre lo senyor del dit lloch, de una, y los vasalls nous pobladors, de altra, que lo ministre y guardià que per qualsevol temps serà en lo dit lloch de Seniera lo haja de posar y elegir lo senyor de dit lloch que hui és y per temps serà y despedir-lo quant ben vist li sia. Y lo salari de aquell se pague y haja de pagar de tot montó en la hera segons és ús y pràtica.

[24] Que no·s puga batre sinó en les heres de Seniera.

Ittem, és estat pactat, avengut y concordat entre lo senyor de dit lloch, de una, y los vasalls y nous pobladors, de altra, que tots los vasalls que hui són y per seran del dit lloch de Seniera tinguen obligació de batre tots los grans y esplets que-s colliran en

225. Al margen: «Vinyes al $6^{\circ}$ ».

226. Al margen: «2 sous por fanecada de vinya».

227. Al margen: «Paja la 4" parte». 
lo terme de dit lloch en les heres del lloch de Seniera y no en altra part, sots pena de perdició dels tals grans applicadors als graners del senyor y altres penes a arbitre del senyor que hui és y per temps serà en dit lloch.

[25] Que los vasalls conserven portes y portals.

Ittem, és estat pactat, avengut y concordat entre lo senyor del dit lloch, de una, y dits vasalls nous pobladors, //de altra, que los vehins, vasalls y pobladors de Seniera que hui són y per temps seran tinguen obligació de conservar y conserven a sos gastos propris los portals, portes y portells per a la custòdia, guarda y conservació de aquells $y$ de dit lloch tenint aquells en conreu.

[26] Lo senyor se reserva los arbres silvestres.

Ittem, és estat pactat, avengut y concordat entre lo senyor de dit lloch, de una, y los vasalls y nous pobladors, de altra, que lo senyor de dit lloch que hui és y per tems serà se reserva ver sí e sos sucsessors tots los arbres silvestres que no fan fruit en lo terme de dit lloch plantats y que eixiran en aquell a fer-ne a ses voluntats.

[27] Jurisdictió.

Ittem, és estat pactat, avengut y concordat entre lo senyor del dit lloch de Seniera, de una, y los dits nous pobladors y vasalls de dit lloch, de altra, que lo dit don Francisco Joachim Sans, senyor de dit lloch de Senyera, per a conservació de les regalies de dit lloch puga imposar qualssevols penes per a conservació dels fruits, rendes y regalies a dit senyor pertanyents, per a conservació de tot lo dispost en la present capitulació. Y axí mateix, en execució de lo desusdit, puixa fer, provehir e manar se fasen qualssevols crides, prohibicions y manaments y que se hajen de observar, guardar y obtenperar les coses per dit senyor provehides y manades per la bona administratió de la justítia, pau, quietut, tranquilitat e seguretat de les perçones dels nous pobladors y vasalls que ara són y per temps seran en dit lloch de Seniera y bon govern de aquell, inposant qualssevols penes, així corporals com pecuniàries, segons Furs y privilegis del present regne. Reservant-se lo dit senyor per a sí y a sos sucsessors en dit lloch tota la jurisdictió, així civil com criminal, al que per//Furs e privilegis del present regne et àlias de justícia li és consedida y otorgada, y aquella que sos antesessors y senyors en dit lloch de Seniera an acostumat tenir y exersir y an tengut y exersit en lo dit lloch de Seniera.

[28] Que los capitols sien executoris en favor del senyor.

Ittem, és estat pactat, avengut y concordat entre lo dit senyor de Seniera, de una, y los vasalls de dit lloch, de altra, que tots los dits capítols y cascú de aquells se hajen y haja de guardar ad unguem y sien executoris en favor del dit don Francisco Joachim Sanz, senyor de dit lloch, y de tots los sucsessors de aquell tostemps que qualsevol de dits pobladors y vasalls de dit lloch que hui són y per tems seran contravindran a qualsevol de aquells.

Ideo tractata inter nos executori deduçendo et omnia supradicta promissa adinplendo scienter ettcetera thenore presentis ettcetera, ego dictus don Franciscus Joachimus Sanz, dominus dicti loçi de Seniera, de novo stabilio et in infiteutesim (sic) perpetuam conçedo ac trado seu quasi trado vobis dictis Bernardo Marco, justitia, Petro Joanni Alventosa, Michaelli Marco, juratis, Martino Tortajada, natu mayori, Petro Martinez, Martino Tortajada, natu minori, Christoforo Vidal, Sebastiano Glaudes, Joanni Ferraig, 
Petro Rodrigues, Josepho Vanegas, Jacobo Garçia, Thome Alventosa et Petro Saleses, aratoribus, etiam vasallis vicinis dicti loçi presentibus ettcetera, et vestris domos et terras meas quas habeo in dicto loco de Seniera et in territorio et termino illius, cum sensibus, pactis, partitionibus, fructuum, capitulis et condicionibus suppradictis et non aliter nech alio modo cum hoc quod in dictis domibus et terris vos et vestri non eligatis, proclametis nech eligere nech proclamare possitis alium dominum directum et judiçem nisi me et meos suc-//sessores quoscunque et judiçes quos ego et mei elegerimus et delegaverimus sub pena comissi et non recurretis vos nech vestri sucsessores ad alium judicem sub dicta pena commissi. Et vos et vestri teneatis et teneatur michi et meis anno quolibet solvere fructus, sçensuum, redditus et emolumenta in suppradictis capitulis especificata et contenta et in terminis et forma contentis. Quod stabilimentum etiam facio ad usum et consuetudinem bonorum adquisitorum ad bene meliorandum et non deteriorandum et cum dictis censibus, regaliis, fructibus, particionibus, pactis et condicionibus supradictis et non aliter nech alias nech alio modo. Et promitto vobis et vestris per me et meos façere, habere et tenere dictum stabilimentum et contra illum minime venire, palam vel oculte, aliqua racione et causa sub obligacione meorum ettcetera.

Ad hec autem nos suppradicti omnes viçini et habitatores et vasalli dicti loci de Seniera adquirentes sive recipientes a vobis suppradicto don Francisco Joachimo Sanz, domino nostro, predictas domos, hereditates et dictum stabilimentum per vos nobis factum, cum pactis, obligacionibus, particionibus, fructuum, çensuum, regaliis et aliis obligacionibus de super resitatis et enarratis, promittimus omnes simul et nemine discrepante et nomine universitatis dicti loci de Seniera et singularium perçonarum illius vobis, dicto don Francisco Joachimo Sanz, domino dicti loci de Seniera, presenti acceptanti et sucsessoribus vestris in dicto loco, facere, habere, tenere, complere et observare in totum omnia contenta in dicto instrumento stabilimenti et in capitulis et particionibus suppradictis, et solvere et pacare vobis et vestris anno quolibet in suis terminis sensus et fructus de super nomi-//nati, modo et forma superius dictis, et facere et complere omnia predicta ad nos pertinencia.

Et promittimus etiam nos esse bonos et fideles vasallos vestros et sucsessorum vestrorum in dicto loco et promittimus prestare juramentum fidelitatis et ideo cum presenti in presentia notarii et testium infrascriptorum dictum corporale juramentum et homagium fidelitatis et vasallagii in manibus et posse vestris, more solito, prestamus virtute cujus promittimus vobis et vestris esse bonos et fideles vasallos. Et vos, tanquam dominum nostrum, parere et complere omnia suppradicta sub obligacione bonorum nostrorum et dicte universitatis et singularium ejusdem, renunciantes etiam beneficiis dividendarum actionum, Epistole Divi Adriani et foro Valencie ettcetera. Et nomine mulierum scertifficati per notarium infrascriptum de juribus illarum et signanter de beneficiis Senatus Consulti Velleyani ipsis renunciamus dotibus et sponsaliçiis illarum ettcetera. Et nomine minorum renunciamus benefficio restitutionis in integrum et omni alii ettcetera.

Quod est actum in dicto loco de Seniera ettcetera. 
Testes hujus rey sunt Petrus Audinosa, scutifer, et Cosmas Portugues, Villenove Castilionis habitatoris, in dicto loco de Seniera reperti.

Jhesus.

Reçepi propriaque manu exaravi ego Andreas Scoriola, auctoritate inperiali notarius publicus per totas et cunctas dictiones et dominaçiones sacre catolice regie magestati, Xative habitatori, preinseertum capitulacionis estabilimenti instrumentum in his octo papiri foleis presente comprehenso contentum cum protestu salarii illius non soluti e quia ubique tota plena et indubia tribuatur et detur fides hic meum artis notarie appono et depingo sig[signo notarial $]$ num $^{228}$.

228. El cierre de la copia registrada en Manaments y empares es «In quorum fidem et testimonium premissorum ego Andreas Escoriola, notarius preinserti instrumenti receptor, hic meum artis quo utor notari apono et depingo sig[cruz]num». 